Prepared in cooperation with the ClearWater Conservancy and Pennsylvania Department of Environmental Protection

\title{
Water-Budget and Recharge-Area Simulations for Spring Creek and Nittany Creek Basins and Parts of the Spruce Creek Basin, Centre and Huntingdon Counties, Pennsylvania, Water Years 2000-06
}

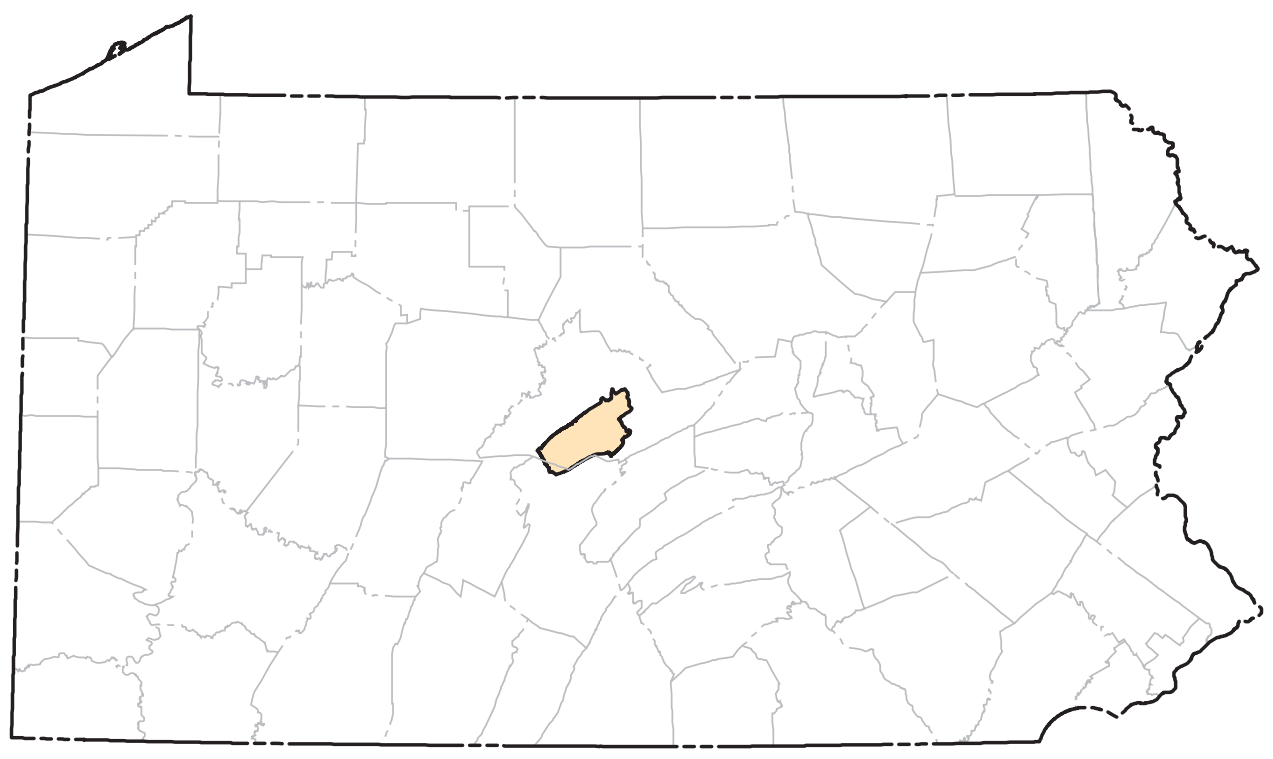

Scientific Investigations Report 2015-5073 
Cover. Map showing location of study area. 


\section{Water-Budget and Recharge-Area Simulations for Spring Creek and Nittany Creek Basins and Parts of the Spruce Creek Basin, Centre and Huntingdon Counties, Pennsylvania, Water Years 2000-06}

By John W. Fulton, Dennis W. Risser, Robert S. Regan, John F. Walker, Randall J. Hunt, Richard G. Niswonger, Scott A. Hoffman, and Stephen L. Markstrom

Prepared in cooperation with the ClearWater Conservancy and Pennsylvania Department of Environmental Protection

Scientific Investigations Report 2015-5073 


\title{
U.S. Department of the Interior SALLY JEWELL, Secretary
}

\section{U.S. Geological Survey Suzette M. Kimball, Acting Director}

\author{
U.S. Geological Survey, Reston, Virginia: 2015
}

For more information on the USGS - the Federal source for science about the Earth, its natural and living resources, natural hazards, and the environment—visit http://www.usgs.gov or call 1-888-ASK-USGS.

For an overview of USGS information products, including maps, imagery, and publications, visit http://www.usgs.gov/pubprod/.

Any use of trade, firm, or product names is for descriptive purposes only and does not imply endorsement by the U.S. Government.

Although this information product, for the most part, is in the public domain, it also may contain copyrighted materials as noted in the text. Permission to reproduce copyrighted items must be secured from the copyright owner.

Suggested citation:

Fulton, J.W., Risser, D.W., Regan, R.S., Walker, J.F., Hunt, R.J., Niswonger, R.G., Hoffman, S.A., and Markstrom, S.L., 2015, Water-budgets and recharge-area simulations for the Spring Creek and Nittany Creek Basins and parts of the Spruce Creek Basin, Centre and Huntingdon Counties, Pennsylvania, Water Years 2000-06: U.S. Geological Survey Scientific Investigations Report 2015-5073, 86 p, http://dx.doi.org/10.3133/sir20155073.

ISSN 2328-0328 (online) 


\section{Acknowledgments}

The authors thank Jennifer Shuey (ClearWater Conservancy), Kathryn Ombalksi (ClearWater Conservancy), and Michael Hill (Pennsylvania Department of Environmental Protection) for collaborating on this project. We thank William Werkheiser [U.S. Geological Survey (USGS)], Ronald Thompson (USGS, retired), and George Leavesley (USGS, retired) for having the vision to undertake this effort. Matt Ely (USGS), David Bjerklie (USGS), and Daniel Goode (USGS) provided constructive criticism and review of the manuscript. Thank you to Lauren Hay (USGS) for assisting with model development and PRMS calibration. Roland Viger (USGS) assisted with model parameterization and ArcMap datasets. Elizabeth Hittle (USGS) assisted with implementing MISTE to estimate missing daily discharge values. Thank you to Kevin Hlywiak (National Weather Service) and Paul Knight and his staff (Pennsylvania Climatologist Office) for providing meteorological data used to parameterize the GSFLOW model. The Spring Creek Watershed Technical Steering Committee and in particular Todd Giddings (Giddings and Associates) and Lawrence Fennessey (Pennsylvania State University), Robert Carline (USGS, retired), Robert Cooper (Pennsylvania State University), Robert Donaldson (Centre County Planning Office, Retired), Walter Ebaugh (Nittany Geoscience, retired), Christopher Finton (Meiser \& Earl), John Gaudlip (Pennsylvania State University), Jay Lynch (Meiser \& Earl), and Mark Ralston (Converse Consultants) offered valuable local knowledge about the basin. Thank you to the Spring Creek Watershed Commission and, in particular, Dennis Haemeister. 


\section{Contents}

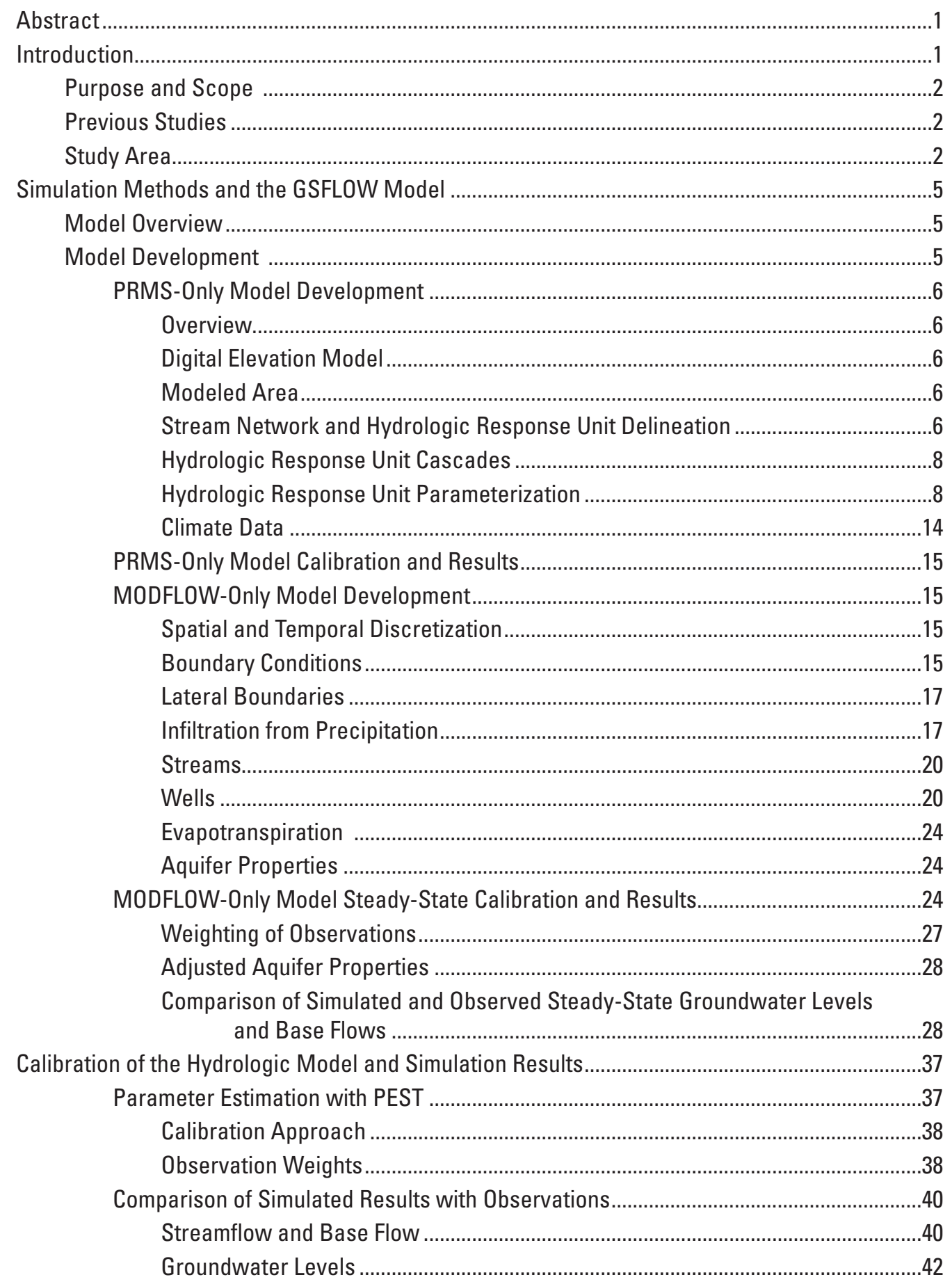


Water Budget and Groundwater Recharge .................................................................................4

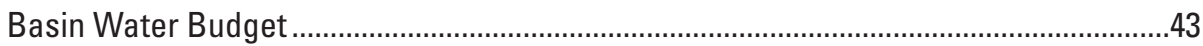

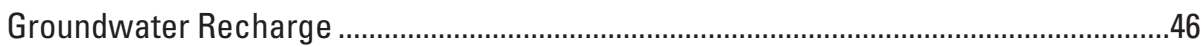

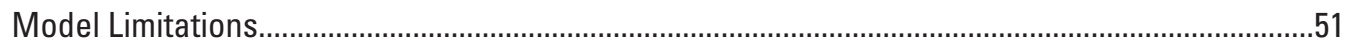

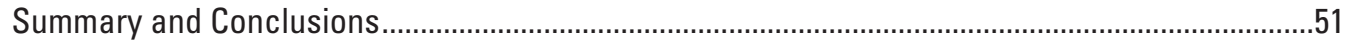

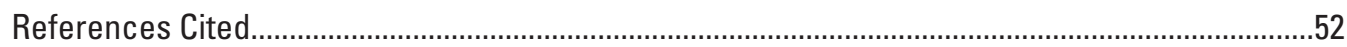

Appendix. Results for All of the Calibration Targets for GSFLOW Simulations for Water Years

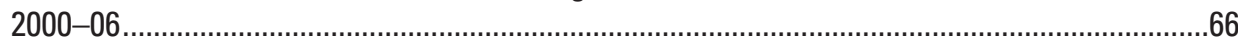

\section{Figures}

1. Map showing location of Spring Creek and Nittany Creek Basins and parts of the Spruce Creek Basin, Centre and Huntingdon Counties, Pennsylvania

2. Map showing delineation of subbasins in Spring Creek and Nittany Creek Basins and parts of the Spruce Creek Basin, Centre and Huntingdon Counties, Pennsylvania

3. Flow chart of the strategy for development of the GSFLOW model for Spring Creek and Nittany Creek Basins and parts of the Spruce Creek Basin, Centre and Huntingdon Counties, Pennsylvania

4. Map showing stream network and locations of streamgages used to derive streamflow and base-flow observations for calibrating the MODFLOW-NWT, PRMS, and GSFLOW models in Spring Creek and Nittany Creek Basins and parts of the Spruce Creek Basin, Centre and Huntingdon Counties, Pennsylvania .

5. Map showing bedrock geologic units of Spring Creek and Nittany Creek Basins and parts of the Spruce Creek Basin, Centre and Huntingdon Counties, Pennsylvania

6. Map showing location of 829 hydrologic response units in Spring Creek and Nittany Creek Basins and parts of the Spruce Creek Basin, Centre and Huntingdon Counties, Pennsylvania

7. Map showing general soil types in Spring Creek and Nittany Creek Basins and parts of the Spruce Creek Basin, Centre and Huntingdon Counties, Pennsylvania

8. Map showing land cover in Spring Creek and Nittany Creek Basins and parts of the Spruce Creek Basin, Centre and Huntingdon Counties, Pennsylvania

9. Map showing mean infiltration rate simulated by PRMS for Spring Creek and Nittany Creek Basins and parts of the Spruce Creek Basin, Centre and Huntingdon Counties, Pennsylvania, water years 2000-06 
10. Map showing finite-difference grid and boundaries of the MODFLOW-NWT model for Spring Creek and Nittany Creek Basins and parts of the Spruce Creek Basin, Centre and Huntingdon Counties, Pennsylvania ..... 19

11. Map showing location of surface-water withdrawals and discharges simulated by the MODFLOW-NWT model for Spring Creek and Nittany Creek Basins and parts of the Spruce Creek Basin, Centre and Huntingdon Counties, Pennsylvania........21

12. Map showing location of groundwater withdrawals simulated by the MODFLOW-NWT model for Spring Creek and Nittany Creek Basins and parts of the Spruce Creek Basin, Centre and Huntingdon Counties, Pennsylvania. .22

13. Map showing locations of groundwater wells with groundwater-level data used for calibrating the MODFLOW-NWT model for Spring Creek and Nittany Creek Basins and parts of the Spruce Creek Basin, Centre and Huntingdon Counties, Pennsylvania

14. Map showing horizontal hydraulic conductivity zone parameters for layer 1 of the MODFLOW-NWT model for Spring Creek and Nittany Creek Basins and parts of the Spruce Creek Basin, Centre and Huntingdon Counties, Pennsylvania

15. Map showing horizontal hydraulic conductivity zone parameters for layer 2 of the MODFLOW-NWT model for Spring Creek and Nittany Creek Basins and parts of the Spruce Creek Basin, Centre and Huntingdon Counties, Pennsylvania

16. Map showing horizontal hydraulic conductivity zone parameters for layer 3 of the MODFLOW-NWT model for Spring Creek and Nittany Creek Basins and parts of the Spruce Creek Basin, Centre and Huntingdon Counties, Pennsylvania

17. Map showing areas of horizontal anisotropy in layer 1 of the MODFLOW-NWT model for Spring Creek and Nittany Creek Basins and parts of the Spruce Creek Basin, Centre and Huntingdon Counties, Pennsylvania

18. Map showing areas of specific yield in layers 1 and 2 of the MODFLOW-NWT model for Spring Creek and Nittany Creek Basins and parts of the Spruce Creek Basin, Centre and Huntingdon Counties, Pennsylvania

19. Map showing areas of specific yield in layer 3 of the MODFLOW-NWT model for Spring Creek and Nittany Creek Basins and parts of the Spruce Creek Basin, Centre and Huntingdon Counties, Pennsylvania

20. Map showing water-table elevations simulated by the MODFLOW-NWT model for Spring Creek and Nittany Creek Basins and parts of the Spruce Creek Basin, Centre and Huntingdon Counties, Pennsylvania

21. Diagram showing hydraulic conductivities through column 119 of the MODFLOW-NWT model for Spring Creek and Nittany Creek Basins and parts of the Spruce Creek Basin, Centre and Huntingdon Counties, Pennsylvania .

22. Graphs showing observed steady-state groundwater levels in relation to $A$, MODFLOW-NWT simulated elevations and $B$, the difference between simulated and observed elevations for 257 wells in Spring Creek and Nittany Creek Basins and parts of the Spruce Creek Basin, Centre and Huntingdon Counties, Pennsylvania.

23. Graph showing observed steady-state base flows and steady-state base flows simulated by the MODFLOW-NWT model at 17 sites in Spring Creek and Nittany Creek Basins and parts of the Spruce Creek Basin, Centre and Huntingdon Counties, Pennsylvania, water years 2000-06 
24. Graph showing summary of annual water-budget terms from the GSFLOW simulation, Spring Creek and Nittany Creek Basins and parts of the Spruce Creek Basin, Centre and Huntingdon Counties, water years 2000-06.

25. Graph showing daily fluxes of precipitation (basinppt), evapotranspiration (basinactet), and streamflow (basinstrmflow) from the GSFLOW Comma Separated Value (CSV) output file.

26. Graph showing daily fluxes of precipitation (basinppt) and recharge from the unsaturated zone to the saturated zone (uzf_recharge) from the GSFLOW Comma Separated Value (CSV) output file

27. Graph showing daily fluxes of streamflow (basinstrmflow) and recharge from the unsaturated zone to the saturated zone (uzf_recharge) derived from the GSFLOW Comma Separated Value (CSV) output file.

28. Map showing net recharge simulated by GSFLOW in Spring Creek and Nittany Creek Basins and parts of the Spruce Creek Basin, Centre and Huntingdon Counties, Pennsylvania, water year 2001.

29. Map showing net recharge simulated by GSFLOW in Spring Creek and Nittany Creek Basins and parts of the Spruce Creek Basin, Centre and Huntingdon Counties, Pennsylvania, water year 2004.

30. Map showing difference in net recharge between water years (2004 minus 2001) simulated by GSFLOW in Spring Creek and Nittany Creek Basins and parts of the Spruce Creek Basin, Centre and Huntingdon Counties, Pennsylvania

\section{Tables}

1. Precipitation Runoff Modeling System parameter values assigned to hydrologic response units for Spring Creek and Nittany Creek Basins and parts of the Spruce Creek Basin, Centre and Huntingdon Counties, Pennsylvania.

2. Meteorological stations used to generate the climate data for the PrecipitationRunoff Modeling System-only simulations for Spring Creek and Nittany Creek Basins and parts of the Spruce Creek Basin, Centre and Huntingdon Counties, Pennsylvania

3. Description of manual calibration parameters with ranges for Spring Creek and Nittany Creek Basins and parts of the Spruce Creek Basin, Centre and Huntingdon Counties, Pennsylvania, water years 2000-06

4. Water budget components from the Precipitation-Runoff Modeling System-only simulation to generate the steady-state infiltration distribution for Spring Creek and Nittany Creek Basins and parts of the Spruce Creek Basin, Centre and Huntingdon Counties, Pennsylvania, water years 2000-06

5. Discharges to streams and withdrawals from streams simulated by using the Streamflow-Routing Package of MODFLOW-NWT model for Spring Creek and Nittany Creek Basins and parts of the Spruce Creek Basin, Centre and Huntingdon Counties, Pennsylvania.

6. Groundwater withdrawals simulated using the MODFLOW-NWT steady-state model for Spring Creek and Nittany Creek Basins and parts of the Spruce Creek Basin, Centre and Huntingdon Counties, Pennsylvania 
7. Parameters used to represent the hydraulic conductivity of geologic units in the MODFLOW-NWT steady-state model and horizontal hydraulic conductivity values from previous studies for Spring Creek and Nittany Creek Basins and parts of the Spruce Creek Basin, Centre and Huntingdon Counties, Pennsylvania........63

8. Sources of streamflow data and groundwater levels used to adjust aquifer properties in the MODFLOW-NWT steady-state model for Spring Creek and Nittany Creek Basins and parts of the Spruce Creek Basin, Centre and Huntingdon Counties, Pennsylvania

9. Base-flow values and weights used to adjust the MODFLOW-NWT steady-state model for Spring Creek and Nittany Creek Basins and parts of the Spruce Creek Basin, Centre and Huntingdon Counties, Pennsylvania.....

10. Adjusted values and sensitivities of parameters used in the steady-state MODFLOW-NWT model for Spring Creek and Nittany Creek Basins and parts of the Spruce Creek Basin, Centre and Huntingdon Counties, Pennsylvania .

11. Parameters used in the calibration of the coupled model for Spring Creek and Nittany Creek Basins and parts of the Spruce Creek Basin, Centre and Huntingdon Counties, Pennsylvania.

12. Final weights used for groundwater-level data in the PEST transient calibration of the coupled model for Spring Creek and Nittany Creek Basins and parts of the Spruce Creek Basin, Centre and Huntingdon Counties, Pennsylvania

13. Final weights used for the streamflow data in the PEST transient calibration of the coupled model for Spring Creek and Nittany Creek Basins and parts of the Spruce Creek Basin, Centre and Huntingdon Counties, Pennsylvania .

14. Nash-Sutcliffe coefficients of model efficiency for streamflow calibration targets in the Spring Creek and Nittany Creek Basins and parts of the Spruce Creek Basin, Centre and Huntingdon Counties, Pennsylvania, water years 2000-06.

15. Annual water budgets from the GSFLOW simulation for Spring Creek and Nittany Creek Basins and parts of the Spruce Creek Basin, Centre and Huntingdon Counties, Pennsylvania, water years 2000-06

16. Simulated flux of recharge from the unsaturated zone to the saturated zone (uzf_recharge) derived from the GSFLOW Comma Separated Value (CSV) output file 


\section{Conversion Factors}

[Inch/Pound to International System of Units[

\begin{tabular}{|c|c|c|}
\hline Multiply & By & To obtain \\
\hline \multicolumn{3}{|c|}{ Length } \\
\hline inch (in.) & 2.54 & centimeter $(\mathrm{cm})$ \\
\hline foot $(\mathrm{ft})$ & 0.3048 & $\operatorname{meter}(\mathrm{m})$ \\
\hline mile (mi) & 1.609 & kilometer $(\mathrm{km})$ \\
\hline \multicolumn{3}{|c|}{ Area } \\
\hline acre & 4,047 & square meter $\left(\mathrm{m}^{2}\right)$ \\
\hline square foot $\left(\mathrm{ft}^{2}\right)$ & 0.09290 & square meter $\left(\mathrm{m}^{2}\right)$ \\
\hline square inch $\left(\mathrm{in}^{2}\right)$ & 6.452 & square centimeter $\left(\mathrm{cm}^{2}\right)$ \\
\hline square mile $\left(\mathrm{mi}^{2}\right)$ & 2.590 & square kilometer $\left(\mathrm{km}^{2}\right)$ \\
\hline \multicolumn{3}{|c|}{ Volume } \\
\hline gallon (gal) & 0.003785 & cubic meter $\left(\mathrm{m}^{3}\right)$ \\
\hline million gallons (Mgal) & 3,785 & cubic meter $\left(\mathrm{m}^{3}\right)$ \\
\hline cubic inch $\left(\right.$ in $\left.^{3}\right)$ & 16.39 & cubic centimeter $\left(\mathrm{cm}^{3}\right)$ \\
\hline cubic foot $\left(\mathrm{ft}^{3}\right)$ & 0.02832 & cubic meter $\left(\mathrm{m}^{3}\right)$ \\
\hline \multicolumn{3}{|c|}{ Flow rate } \\
\hline foot per second (ft/s) & 0.3048 & meter per second $(\mathrm{m} / \mathrm{s})$ \\
\hline foot per day (ft/d) & 0.3048 & meter per day $(\mathrm{m} / \mathrm{d})$ \\
\hline foot per year (ft/yr) & 0.3048 & meter per year $(\mathrm{m} / \mathrm{yr})$ \\
\hline cubic foot per second $\left(\mathrm{ft}^{3} / \mathrm{s}\right)$ & 0.02832 & cubic meter per second $\left(\mathrm{m}^{3} / \mathrm{s}\right)$ \\
\hline $\begin{array}{l}\text { cubic foot per second per square } \\
\text { mile }\left[\left(\mathrm{ft}^{3} / \mathrm{s}\right) / \mathrm{mi}^{2}\right]\end{array}$ & 0.01093 & $\begin{array}{l}\text { cubic meter per second per square } \\
\text { kilometer }\left[\left(\mathrm{m}^{3} / \mathrm{s}\right) / \mathrm{km}^{2}\right]\end{array}$ \\
\hline gallon per minute (gal/min) & 0.06309 & liter per second $(\mathrm{L} / \mathrm{s})$ \\
\hline gallon per day (gal/d) & 0.003785 & cubic meter per day $\left(\mathrm{m}^{3} / \mathrm{d}\right)$ \\
\hline million gallons per day (Mgal/d) & 0.04381 & cubic meter per second $\left(\mathrm{m}^{3} / \mathrm{s}\right)$ \\
\hline inch per year (in/yr) & 25.4 & millimeter per year $(\mathrm{mm} / \mathrm{yr})$ \\
\hline \multicolumn{3}{|c|}{ Pressure } \\
\hline atmosphere, standard (atm) & 101.3 & kilopascal $(\mathrm{kPa})$ \\
\hline inch of mercury at $60^{\circ} \mathrm{F}$ (in $\mathrm{Hg}$ ) & 3.377 & kilopascal $(\mathrm{kPa})$ \\
\hline pound per square inch $\left(\mathrm{lb} / \mathrm{in}^{2}\right)$ & 6.895 & kilopascal $(\mathrm{kPa})$ \\
\hline \multicolumn{3}{|c|}{ Hydraulic conductivity } \\
\hline foot per day $(\mathrm{ft} / \mathrm{d})$ & 0.3048 & meter per day $(\mathrm{m} / \mathrm{d})$ \\
\hline
\end{tabular}

Temperature in degrees Celsius $\left({ }^{\circ} \mathrm{C}\right)$ may be converted to degrees Fahrenheit $\left({ }^{\circ} \mathrm{F}\right)$ as:

$$
{ }^{\circ} \mathrm{F}=\left(1.8 \times{ }^{\circ} \mathrm{C}\right)+32 .
$$

Temperature in degrees Fahrenheit $\left({ }^{\circ} \mathrm{F}\right)$ may be converted to degrees Celsius $\left({ }^{\circ} \mathrm{C}\right)$ as:

$$
{ }^{\circ} \mathrm{C}=\left({ }^{\circ} \mathrm{F}-32\right) / 1.8 \text {. }
$$




\section{Datum}

Vertical coordinate information is referenced to the North American Vertical Datum of 1988 (NAVD 88).

Horizontal coordinate information is referenced to the North American Datum of 1983 (NAD 83).

Elevation, as used in this report, refers to distance above the vertical datum.

\section{Abbreviations}

\begin{tabular}{ll} 
CWC & ClearWater Conservancy \\
DEM & digital elevation model \\
EPA & U.S. Environmental Protection Agency \\
ET & evapotranspiration \\
GIS & geographic information system \\
GSFLOW & Groundwater and Surface-water FLOW \\
HRU & hydrologic response unit \\
IDE & Inverse Distance and Elevation \\
MISTE & Mlssing STreamflow Estimation \\
MODFLOW-NWT & Modular Groundwater Flow Model \\
NED & National Elevation Dataset \\
NHD & National Hydrography Dataset \\
PADEP & Pennsylvania Department of Environmental Protection \\
PEST & Parameter ESTimation \\
PRMS & Precipitation-Runoff Modeling System \\
RMSD & root mean squared difference \\
SSURGO & Soil Survey Geographic Database \\
SCWC & Spring Creek Watershed Committee \\
SRBC & Susquehanna River Basin Commission \\
USGS & U.S. Geological Survey \\
UTM & Universal Transverse Mercator \\
VSA & variable source area \\
\hline
\end{tabular}




\title{
Water-Budget and Recharge-Area Simulations for the Spring Creek and Nittany Creek Basins and Parts of the Spruce Creek Basin, Centre and Huntingdon Counties, Pennsylvania, Water Years 2000-06
}

\author{
By John W. Fulton, Dennis W. Risser, Robert S. Regan, John F. Walker, Randall J. Hunt, \\ Richard G. Niswonger, Scott A. Hoffman, and Stephen L. Markstrom
}

\section{Abstract}

This report describes the results of a study by the U.S. Geological Survey in cooperation with ClearWater Conservancy and the Pennsylvania Department of Environmental Protection to develop a hydrologic model to simulate a water budget and identify areas of greater than average recharge for the Spring Creek Basin in central Pennsylvania. The model was developed to help policy makers, natural resource managers, and the public better understand and manage the water resources in the region. The Groundwater and Surfacewater FLOW model (GSFLOW), which is an integration of the Precipitation-Runoff Modeling System (PRMS) and the Modular Groundwater Flow Model (MODFLOW-NWT), was used to simulate surface water and groundwater in the Spring Creek Basin for water years 2000-06. Because the groundwater and surface-water divides for the Spring Creek Basin do not coincide, the study area includes the Nittany Creek Basin and headwaters of the Spruce Creek Basin.

The hydrologic model was developed by the use of a stepwise process: (1) develop and calibrate a PRMS model and steady-state MODFLOW-NWT model; (2) re-calibrate the steady-state MODFLOW-NWT model using potential recharge estimates simulated from the PRMS model, and (3) integrate the PRMS and MODFLOW-NWT models into GSFLOW. The individually calibrated PRMS and MODFLOW-NWT models were used as a starting point for the calibration of the fully coupled GSFLOW model. The GSFLOW model calibration was done by comparing observations and corresponding simulated values of streamflow from 11 streamgages and groundwater levels from 16 wells.

The cumulative water budget and individual water budgets for water years 2000-06 were simulated by using GSFLOW. The largest source and sink terms are represented by precipitation and evapotranspiration, respectively. For the period simulated, a net surplus in the water budget was computed where inflows exceeded outflows by about 1.7 billion cubic feet ( 0.47 inches per year over the basin area); storage increased by about the same amount to balance the budget.

The rate and distribution of recharge throughout the Spring Creek, Nittany Creek, and Spruce Creek Basins is variable as a result of the high degree of hydrogeologic heterogeneity and karst features. The greatest amount of recharge was simulated in the carbonate-bedrock valley, near the toe slopes of Nittany and Tussey Mountains, in the Scotia Barrens, and along the area coinciding with the Gatesburg Formation.

Runoff extremes were observed for water years 2001 (dry year) and 2004 (wet year). Simulated average recharge rates (water reaching the saturated zone as defined in GSFLOW) for 2001 and 2004 were $5.4 \mathrm{in} / \mathrm{yr}$ and $22.0 \mathrm{in} / \mathrm{yr}$, respectively. Areas where simulations show large variations in annual recharge between wet and dry years are the same areas where simulated recharge was large. Those areas where rates of groundwater recharge are much higher than average, and are capable of accepting substantially greater quantities of recharge during wet years, might be considered critical for maintaining the flow of springs, stream base flow, or the source of water to supply wells. The slopes of the Bald Eagle, Tussey, and Nittany Mountains are relatively insensitive to variations in recharge, primarily because of reduced infiltration rates and steep slopes.

\section{Introduction}

The Spring Creek Basin, Nittany Creek Basin, and headwaters of the Spruce Creek Basin in central Pennsylvania (collectively termed the "study basin") have experienced growth and development resulting in land-use change and increased water use in parts of the basins. These changes influence the (1) quantity and availability of surface water and groundwater, (2) surface-water and groundwater interactions, and (3) aquatic resources in the basin. The study basin was identified as one of seven potentially stressed areas in the Susquehanna 
River Basin because of stormwater issues, groundwater contamination, mine dewatering, and diminished streamflow caused by groundwater withdrawals (Susquehanna River Basin Commission, 2005, p. 18-20). To assist water-management agencies in assessing the effects of increased water use and land-use change on surface-water and groundwater resources, the U.S. Geological Survey (USGS) in cooperation with ClearWater Conservancy (CWC) and the Pennsylvania Department of Environmental Protection (PADEP) developed a computer simulation model of the groundwater and surfacewater system by using the coupled groundwater and surfacewater flow model GSFLOW (Markstrom and others, 2008). Because of the variability in hydrologic connectivity between surface-water and groundwater across the study area, a model capable of simulating interactions between the systems was needed. GSFLOW is a useful tool (Mejia and others, 2012; Huntington and Niswonger, 2012) for assessing the effects of land-use change on surface-water and groundwater resources.

\section{Purpose and Scope}

This report describes the development of a GSFLOW computer model and presents the climate, physiographic, geologic, land-use, hydrologic, and streamflow data used to drive the computer model. The data were used to develop a model of the hydrology of the study area capable of accounting for water through the land surface, soils, subsurface, and stream network. Calibration of the model is discussed, and results of the simulations are presented.

The specific objectives of this project were to (1) establish a water budget for the study basin using GSFLOW for water years ${ }^{1} 2000-06$ and (2) identify areas of greater than average recharge that can be used to assist decision makers in managing water resources. By documenting the steps needed to develop a GSFLOW model, the approach described in this report could be used to develop a baseline water budget and to estimate water volume and distribution for various uses or processes, such as drinking water, surface-water runoff, streamflow, and ecological flows for other basins in the Commonwealth of Pennsylvania.

\section{Previous Studies}

Substantive investigations related to the study basin are referenced in Fulton and others (2005), who summarize the hydrologic and physical characteristics of the basins and present a conceptual model for surface-water and groundwater flow. The data and the conceptual model reported by Fulton and others (2005) were used to demonstrate the need for a coupled-regions model, which dynamically accounts for the spatial and temporal distribution of surface water and groundwater.

\footnotetext{
${ }^{1}$ A water year is the 12 -month period that begins October 1 and ends Sep-
tember 30 . It is designated by the year in which it ends.

${ }^{1}$ A water year is the 12 -month period that begins October 1 and ends Sep-
tember 30 . It is designated by the year in which it ends.
}

\section{Study Area}

The study basin is 229 square miles $\left(\mathrm{mi}^{2}\right)$ in Centre and Huntingdon Counties in central Pennsylvania (fig. 1). The study basin incorporates all of Spring Creek and Nittany Creek Basins and the headwaters of the Spruce Creek Basin. The study basin is equivalent to the domain of the GSFLOW model. The Spring Creek Basin is $147 \mathrm{mi}^{2}$, the Nittany Creek Basin is $17 \mathrm{mi}^{2}$, and the headwaters of Spruce Creek Basin in the study area is about $65 \mathrm{mi}^{2}$. The study basin is divided into 14 subbasins in the GSFLOW model (fig. 2).

Water-level maps indicate that groundwater and surfacewater divides do not coincide in the study area (Giddings, 1974; Taylor, 1997). The Spring Creek groundwater basin is approximately $175 \mathrm{mi}^{2}$ (Fulton and others, 2005), which is about $28 \mathrm{mi}^{2}$ larger than the Spring Creek surface-water basin. The study basin includes the groundwater divide that delineates the area of groundwater contribution to the Spring Creek Basin (fig. 1). The contributing area for groundwater flow from Nittany and Spruce Creek Basins, which is captured by Spring Creek, is not a fixed area; thus, it may vary based on hydrologic conditions and nearby groundwater withdrawals (Brachet, 2004).

Two principal hydrologic settings define the study area-a forested, siliciclastic (sandstone and shale) -bedrock upland and a carbonate (limestone and dolomite) -bedrock valley with agricultural, suburban, and urban land uses. The settings differ in physiography, geology, and land use but are linked hydrologically by climate, evapotranspiration, surface runoff, interflow, snowmelt, recharge, and groundwater flow from the uplands, which provide and limit the water available for streamflow and groundwater recharge and discharge within the valley.

Forested, siliciclastic-bedrock uplands bound the study basin to the north and south. The carbonate-bedrock valley is dominated by agricultural and urban land uses and is described by Fulton and others (2005). Direct runoff from upland subbasins is characterized by variable source-area (VSA) hydrology, which is common in well-vegetated, humid areas that contain thin soil layers with large infiltration capacities and laterally continuous, low-permeability zones (Fulton and others, 2005). The carbonate-bedrock units in the valley are highly fractured and contain sinkholes and conduits, which promote rapid recharge and streamflow response to precipitation and snowmelt events and influence the rate and direction of groundwater flow. However, in areas where the residual soil veneer is substantial (greater than 100 feet), wetting fronts are attenuated, and the water-table response to precipitation and snowmelt can be delayed. The carbonate-bedrock units are capable of providing groundwater to wells that withdraw in excess of 1 million gallons of water per day (Fulton and others, 2005). Groundwater in the carbonate-bedrock units ultimately discharges to streams, large springs, wells, and mines, and as evapotranspiration to riparian vegetation. 


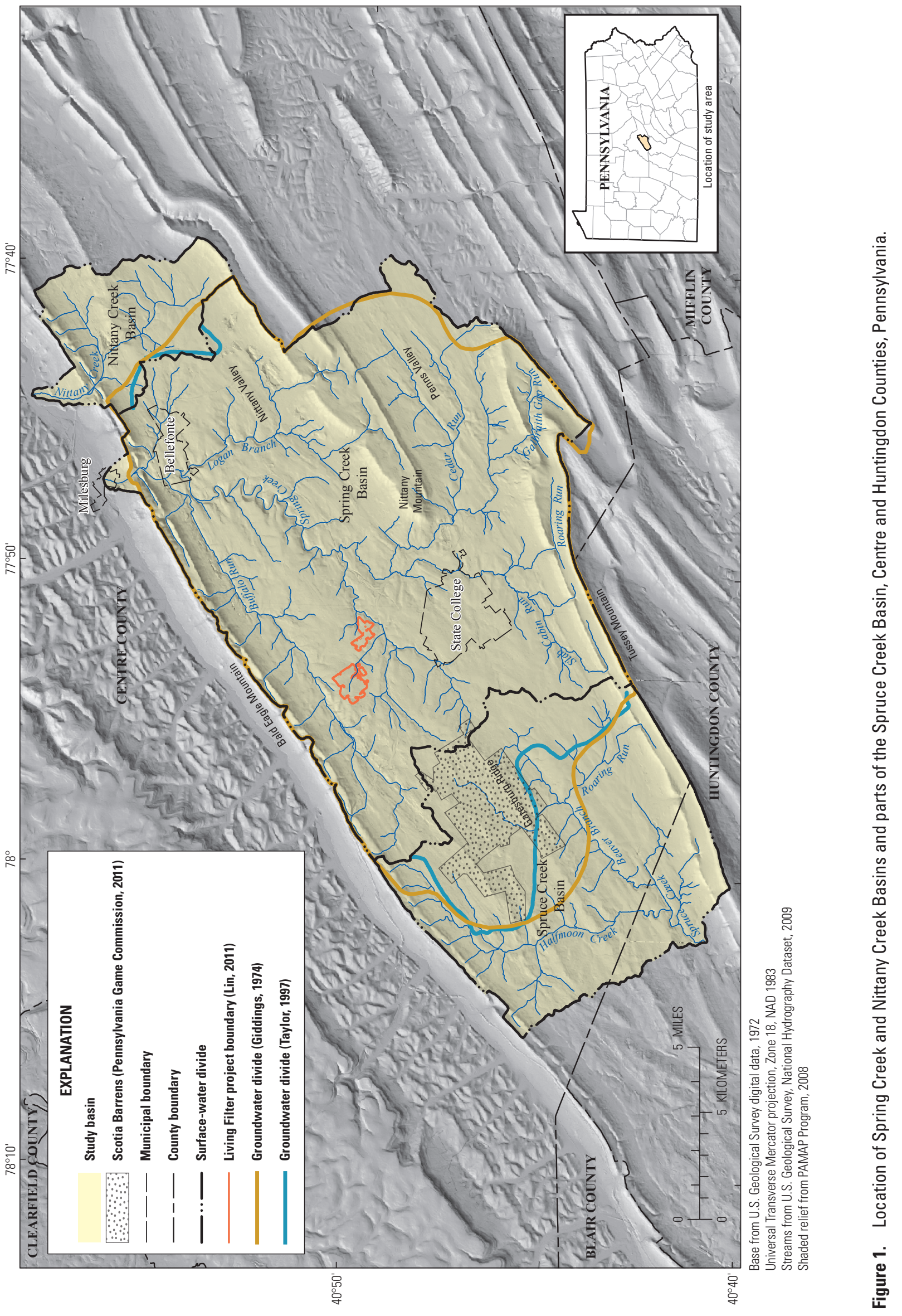




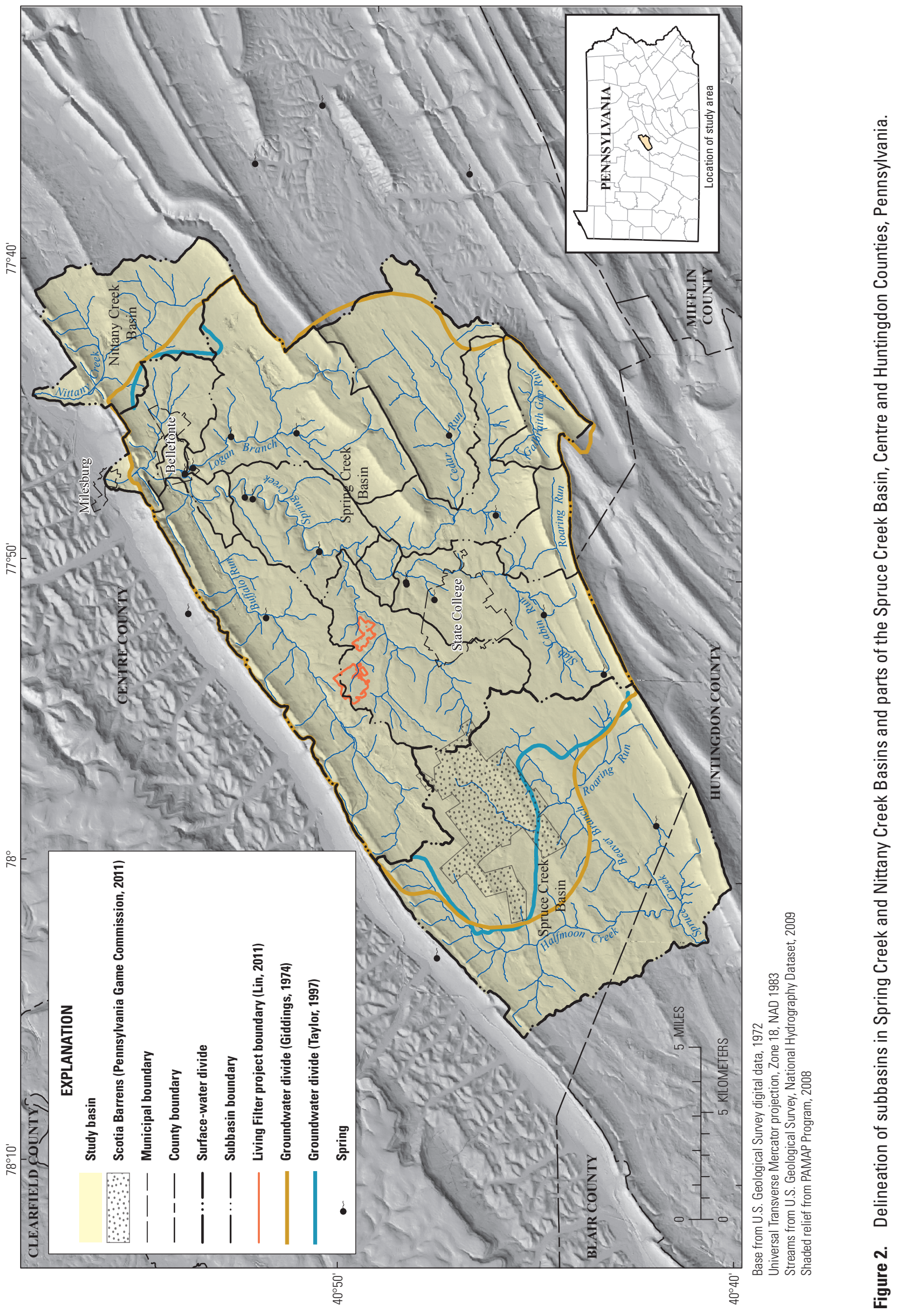


Groundwater recharge typically is greatest during November through May when evapotranspiration rates are minimal. Recharge to the carbonate-bedrock aquifer occurs along six pathways as conceptualized by Parizek (1984): (1) direct infiltration of precipitation into soils and exposed bedrock; (2) concentrated stormwater runoff from the valley into sinkholes; (3) concentrated surface runoff from uplands into sinkholes; (4) diffuse surface runoff from uplands; (5) streamflow losses from perched or intermittent streams on karst terrain; and (6) leakage from underground pipes, disposal of on-lot sewage effluent, and irrigation.

\section{Simulation Methods and the GSFLOW Model}

To simulate the hydrologic cycle, a modified version of GSFLOW (Markstrom and others, 2008; enhanced version 1.1.5) was used in the model domain. It is a physically based, distributed model that simulates coupled groundwater and surface-water flow across the land surface, in the stream network, and within the subsurface variably saturated and saturated materials in single or multiple basins (Markstrom and others, 2008). GSFLOW simulates the timing, feedback, and rates of exchange of water and energy in the atmosphere, canopy, snowpack, pervious and impervious areas of the land surface, soil, unsaturated and saturated zones, streams, lakes, and the effects of wells and surface-water diversions using daily time series climate and water-use data.

The version of GSFLOW (enhanced version 1.1.5) used for this project includes the Newton solution method and the Inverse Distance and Elevation (IDE) module. The Newton solution method is a formulation of MODFLOW-2005, designed to solve problems involving drying and rewetting in hydrogeologic settings, which are dominated by nonlinearity. This feature is particularly important to the study basin, which is characterized by unconfined conditions, steep topography, and surface-water/groundwater interactions.

IDE uses a combination of inverse distance and elevation weighting to interpolate maximum and minimum precipitation and temperature data for each hydrologic response unit (HRU) in the PRMS model. HRUs are spatial discretizations of the land surface, which are commonly represented as polygons or cascading-flow networks to stream segments and possess similar parameters, such as soil type, land cover, land use, and geology.

\section{Model Overview}

GSFLOW integrates two previously documented USGS models - the Precipitation Runoff Modeling System (PRMS) and the three-dimensional, modular groundwater-flow model MODFLOW-NWT (Niswonger and others, 2011). PRMS simulates the distribution of water from the top of the plant canopy to the bottom of the soil zone on the basis of hydrologic and climate variables, such as precipitation, air temperature, potential solar radiation, and evapotranspiration. MODFLOW-NWT simulates the distribution of water from the base of the soil zone, through the unsaturated zone, to the saturated zone, and the discharges of water to streams and the land surface. GSFLOW couples these models within the soil veneer on the basis of soil moisture content, hydrogeologic characteristics, and hydraulic-head differences.

Surface-water/groundwater interactions can occur between the (1) PRMS simulated soil zone and MODFLOWNWT simulated unsaturated zone, (2) PRMS simulated surface runoff and shallow lateral subsurface flow (interflow) to MODFLOW-NWT simulated streams and lakes, and (3) MODFLOW-NWT simulated unsaturated and saturated flow in subsurface areas below the soil zone to streams and lakes. The governing equations of each region are solved separately in an iterative process to balance the dependent variables and conserve mass throughout the model. Flow in the unsaturatedzone beneath the soil zone, streams, and lakes is based on a one-dimensional kinematic-wave approximation to the Richards equation solved by using the UZF Package within MODFLOW-NWT (Niswonger and others, 2007). Streamflow routing is simulated by using the Streamflow Routing Package within MODFLOW-NWT (Niswonger and Prudic, 2005).

The states and fluxes among the soil zone, unsaturated zone, and saturated zone are available to compute a water budget and components of flow in and out of each spatial unit: (1) HRUs, (2) MODFLOW-NWT cells, (3) stream segments, (4) intersection of HRUs and MODFLOW-NWT cells, and (5) intersections between stream segments and MODFLOW-NWT cells or reaches. These spatial units are connected topologically such that simulated flows cascade on the basis of hydrologic gradients. Hydrologic processes are simulated by using a daily time step, and a water budget can be generated by region or stream segment, and for specified time period.

\section{Model Development}

Model development involved a three-step process: (1) develop and calibrate a PRMS model and steady-state MODFLOW-NWT model; (2) re-calibrate the steady-state MODFLOW-NWT model using potential recharge estimates simulated from the PRMS-only model, and (3) integrate the PRMS and MODFLOW-NWT models in the GSFLOW structure and calibrate the coupled model using the individually calibrated PRMS and MODFLOW-NWT models as a starting point. This calibration process was an iterative process occurring as new information and enhancements to GSFLOW were added to improve the model. Calibration was accomplished by comparing observed streamflow and groundwater levels to simulated values with a combination of best professional judgment, manual adjustment of model parameters, and automated 
Water-Budget and Recharge-Area Simulations, Centre and Huntingdon Counties, Pennsylvania, Water Years 2000-06

methods including Parameter Estimation (PEST) (Doherty and Hunt, 2010). Model development is illustrated schematically in figure 3. Note that the MODFLOW-NWT model was calibrated for steady-state conditions (step 1); initial adjustments of aquifer properties were done with a model constructed with a uniform spatial distribution of infiltration, then was recalibrated by using spatially variable estimates of infiltration from the PRMS model output (step 2). The infiltration of water below the root zone simulated by PRMS has been used as input for MODFLOW models in various applications (Bjerklie and others, 2010; Jeton and Maurer, 2007; Lee and Risley, 2001; Steuer and Hunt, 2001; Hunt and Steuer, 2000; Vaccaro, 1992; and Ely and others, 2011). The simulated rate of infiltration below the root zone in PRMS-only can be thought of as potential recharge that will either be added to the saturated zone or be rejected by MODFLOW-NWT.

\section{PRMS-Only Model Development}

An overview of the development of the PRMS model is described in the following section. The digital elevation model (DEM) developed for the PRMS, the modeled area, HRU delineation, HRU cascades, HRU parameterization, climate data, calibration, and results prior to running GSFLOW are discussed.

\section{Overview}

PRMS (Leavesley and others, 1983; Leavesley and Stannard, 1995; Leavesley and others, 2005) is a modular, deterministic, distributed-parameter, physical-process-based model developed to evaluate the hydrologic response to various combinations of climate, land use, topography, and hydrogeology. It is capable of simulating the temporal and spatial distribution and routing of water in the model domain, which comprises single or multiple subbasins of any size and spatial discretization. The phrase "hydrologic response" refers to simulated water flow to and from the atmosphere, canopy, land surface, shallow subsurface, deep aquifers, stream segments, and lakes. A response to normal and extreme precipitation and snowmelt is simulated by basin and is a function of the temporal and spatial variability of hydrologic parameters, water sources and sinks, and storage in a subbasin. Simulated results include a water budget and values for snow dynamics, evapotranspiration, infiltration, streamflow, overland flow, soil-moisture relations, and vertical (recharge), lateral (interflow), and subsurface flows.

Simulation processes are based on physical laws, empirical relations, and associated parameters and attributes of the modeled area. Because these parameters vary spatially and temporally, each subbasin is partitioned into a series of HRUs. Each HRU represents a single, lumped area that is assumed to be homogeneous (with respect to hydrology, physical characteristics, and response) and responds instantaneously and uniformly, when precipitation and snowmelt are added to the
HRU. A comprehensive description of PRMS is found in the GSFLOW documentation and software descriptions (Markstrom and others, 2008).

\section{Digital Elevation Model}

A digital elevation model (DEM) was generated by using the 30-meter grid USGS National Elevation Dataset (NED) (U.S. Geological Survey, 2007), resampled with a 10-meter grid, and processed in accordance with methods described by Viger and Leavesley (2007). Elevations were combined with the USGS National Hydrography Dataset (NHD) (U.S. Geological Survey, 2011) to incorporate known stream locations into the DEM prior to establishing the modeled area.

\section{Modeled Area}

The modeled area was based on the DEM developed for the study basin, including Spring Creek and Nittany Creek Basins, which drain north through water gaps in Bald Eagle Mountain, and the headwaters of Spruce Creek, which is drained by Halfmoon Creek and Beaver Branch (fig. 2). Spruce Creek was included in the domain so that the groundwater divide (fig. 1) near the headwaters of Spring Creek and Spruce Creek could be simulated dynamically as hydrologic conditions varied temporally. The Nittany Creek Basin was included to allow an exchange of groundwater between Spring Creek and Nittany Creek Basins.

\section{Stream Network and Hydrologic Response Unit Delineation}

The stream network and HRU delineation was simplified by using a geographic information system (GIS) database. Spatial variations in basin characteristics were determined by using the database and standard spatial processing techniques similar to those described by Battaglin and others (1993), Jeton (2000), and Jeton and others (1996). Coordinates in the database were assumed to refer to a Cartesian coordinate system with Universal Transverse Mercator (UTM), zone 18, Northern Hemisphere, with North American Datum (NAD) 1983 as the horizontal control datum.

A stream network was generated by using the DEM to create stream segments based on contributing area. The intersection of stream segments and MODFLOW-NWT cells were used in conjunction with the streamflow-routing package (SFR2) in MODFLOW-NWT to create the routing network used in GSFLOW. Surface runoff and interflow were added to stream reaches by connecting HRUs to stream segments. Each stream segment was associated with an HRU representing the riparian area approximated by a 656 -foot (200-meter) distance on each side of the segment. The riparian areas (or stream buffers) were needed to optimize the surface-water and groundwater interaction along the stream network and to assure that groundwater discharge in riparian areas was not routed to upslope HRUs. 


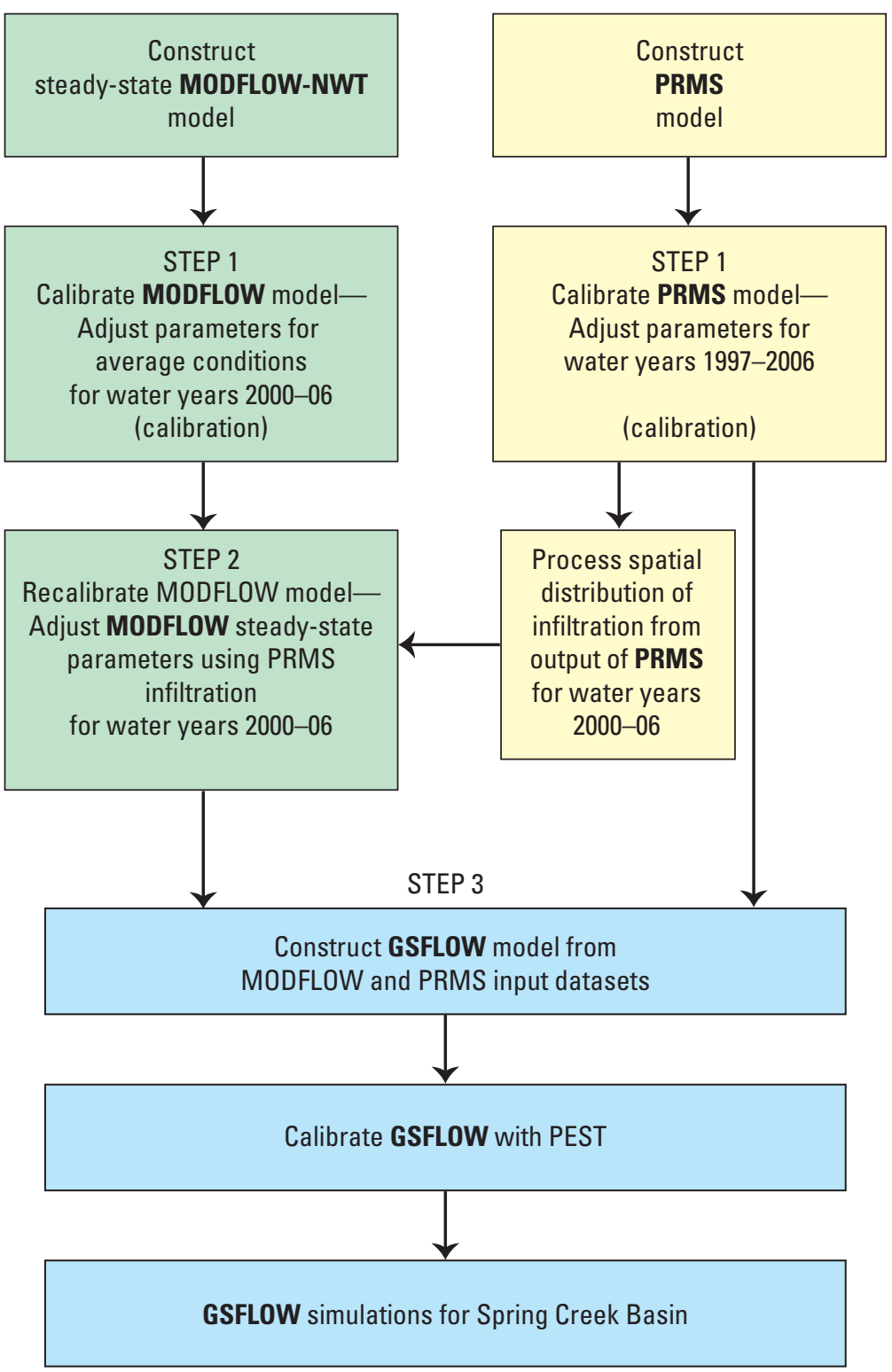

Figure 3. The strategy for development of the GSFLOW model for Spring Creek and Nittany Creek Basins and parts of the Spruce Creek Basin, Centre and Huntingdon Counties, Pennsylvania. 
Water-Budget and Recharge-Area Simulations, Centre and Huntingdon Counties, Pennsylvania, Water Years 2000-06

Flow direction and flow accumulation were computed for the outlet of each HRU from the DEM and used to compute contributing areas. The headwater point of each stream segment was established on the basis of a contributing-area threshold of approximately $15 \mathrm{mi}^{2}$; however, additional headwater streams were added manually at locations of particular interest, such as locations where streams flow into the Spring Creek Basin that do not meet the contributing-area threshold. The stream network (fig. 4) consisted of stream segments with an upper boundary as a headwater point, confluence point, or USGS or CWC streamgage and a lower boundary as a confluence point, USGS or CWC streamgage, or subbasin outlet. The stream network was used to define the left- and rightbank contributing areas and delineate initial HRUs associated with each stream segment. The initial HRU delineations were refined on the basis of soil type, geology (fig. 5), elevation, stream buffers, toe-slope boundaries, and the active MODFLOW boundary. The resulting HRUs were parameterized on the basis of areally weighted averages of subbasin characteristics - soil type, land cover, land use, and geology (Markstrom and others, 2008). GIS processing was used to remove small HRUs by merging them into adjacent, hydrologically similar HRUs (fig. 6). The Spring Creek model is composed of 14 subbasins, 829 HRUs, and 387 stream segments. The 14 subbasins are shown in figure 2.

\section{Hydrologic Response Unit Cascades}

The HRU map was analyzed to determine the cascadingflow paths for routing flow. There are multiple paths. Some HRUs cascade to one or more adjacent HRUs (upslope and downslope), some cascade to a stream segment, some terminate in swale HRUs, and some cascade to multiple stream segments. Swale HRUs were used to simulate sink holes and closed depressions on the land surface. Routines were selected to determine parameters that describe the cascade (routing surface runoff and interflow from upslope HRUs to downslope HRUs) connectivity of HRUs with the stream network. The cascade flow network was determined topologically by using GIS processing of the DEM. HRUs were grouped to define each subbasin as the contributing area to the terminus of any stream segment of interest, such as at a streamgage. Each HRU is included in a single subbasin; thus, HRUs included in a subbasin upstream from another subbasin are treated as a contributing subbasin to a downstream subbasin. HRU-toHRU and HRU-to-stream segment cascade assignments are described in Markstrom and others (2008, p. 33-34). Flow between HRUs (cascades) that is not directly connected to a stream segment is based on topological parameters for routing surface runoff and interflow from upslope HRUs to downslope HRUs and stream segments. For PRMS-only simulations, groundwater was routed by using a similar cascading flow network. Groundwater PRMS cascades differ from HRU cascades in that groundwater reservoirs (GWR) cannot be swales. GWR cascades were the initial cascade flow paths, whereas the HRU cascade network was modified to account for swales.

\section{Hydrologic Response Unit Parameterization}

Initial HRU parameterization, including flow coefficients (gwflow_coef, slowcoef_lin, ssflow_coeff, ssr2gw_exp, ssr2gw_rate), was based on the physical characteristics of the subbasins and PRMS model defaults. Geospatial datasets related to elevation, slope, sinks, HRU area, hydraulic conductivity, aspect, vegetation type, soil type, land use, hydrology, aspect, and precipitation distribution were processed, and PRMS parameters were assigned to each HRU. Data in raster format (a gridded data structure made of rows and columns) and vector format (discrete coordinates that can be used as points or connected to create lines and polygons) were compiled to produce a database of input geospatial datasets. Sources of geospatial data include the USGS NED for elevation (U.S. Geological Survey, 2007) where slope and aspect calculations were derived by using GIS software ArcGIS version 9.2; state geology data from Pennsylvania (Pennsylvania Department of Conservation and Natural Resources, 2001); land-cover and impervious-surface data from the 2001 National Land Cover Database (Multi-Resolution Land Characteristics Consortium, 2001); and soils data (fig. 7), which were originally from the Soil Survey Geographic (SSURGO) database (Natural Resources Conservation Service, 2006) and were further processed with value-added soil characteristics (Miller and White, 1998). Selected reclassification tables (Viger and Leavesley, 2007) were used with land-cover data (fig. 8) to assist in refining the HRU characteristics. The sources of values used for selected distributed PRMS model parameters are listed in table 1 (at end of report), along with ranges of values used. 


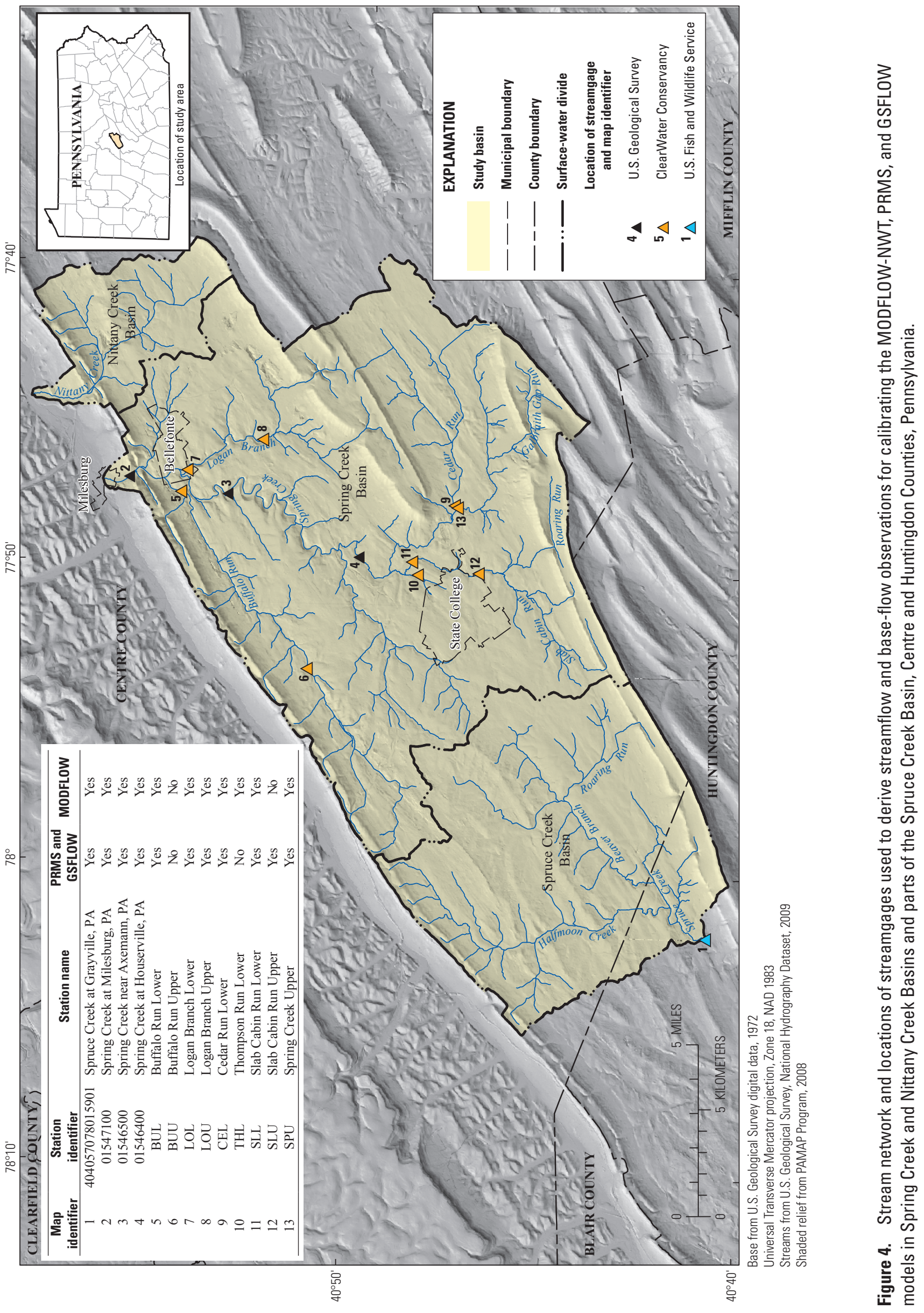




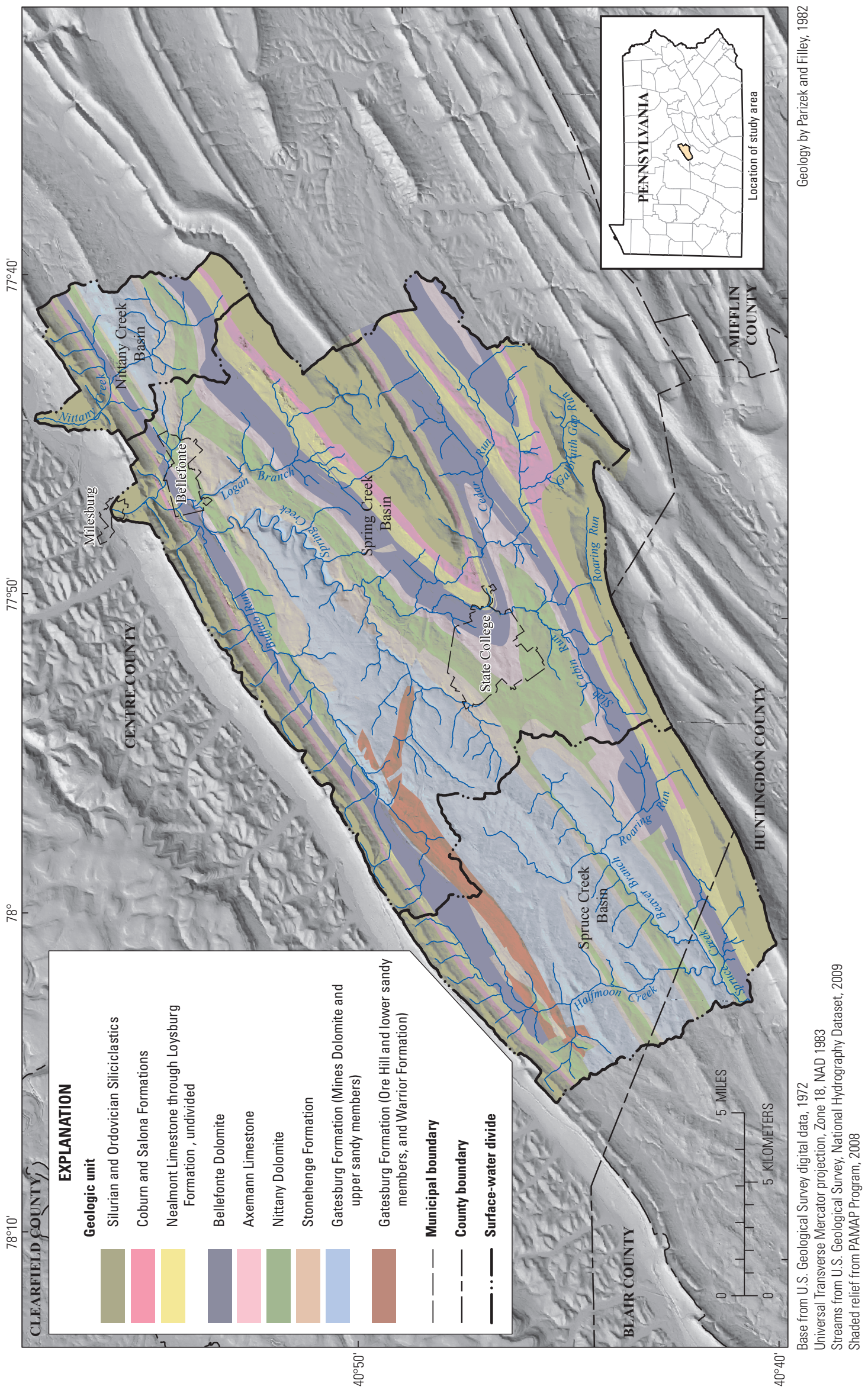

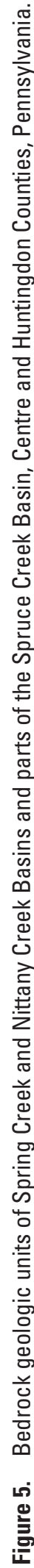




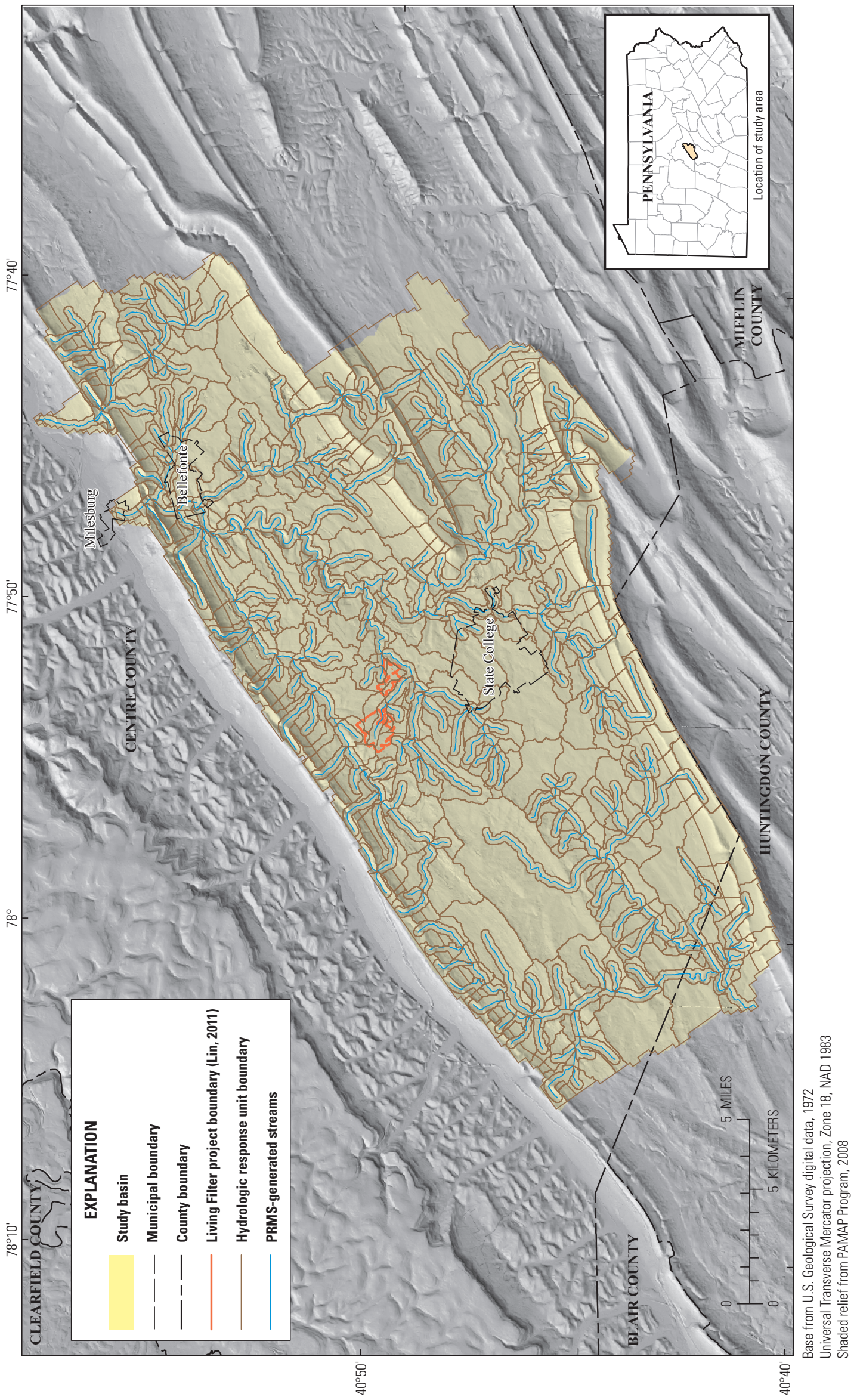

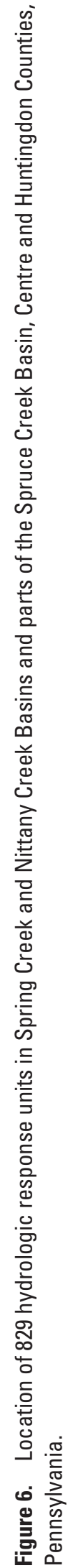




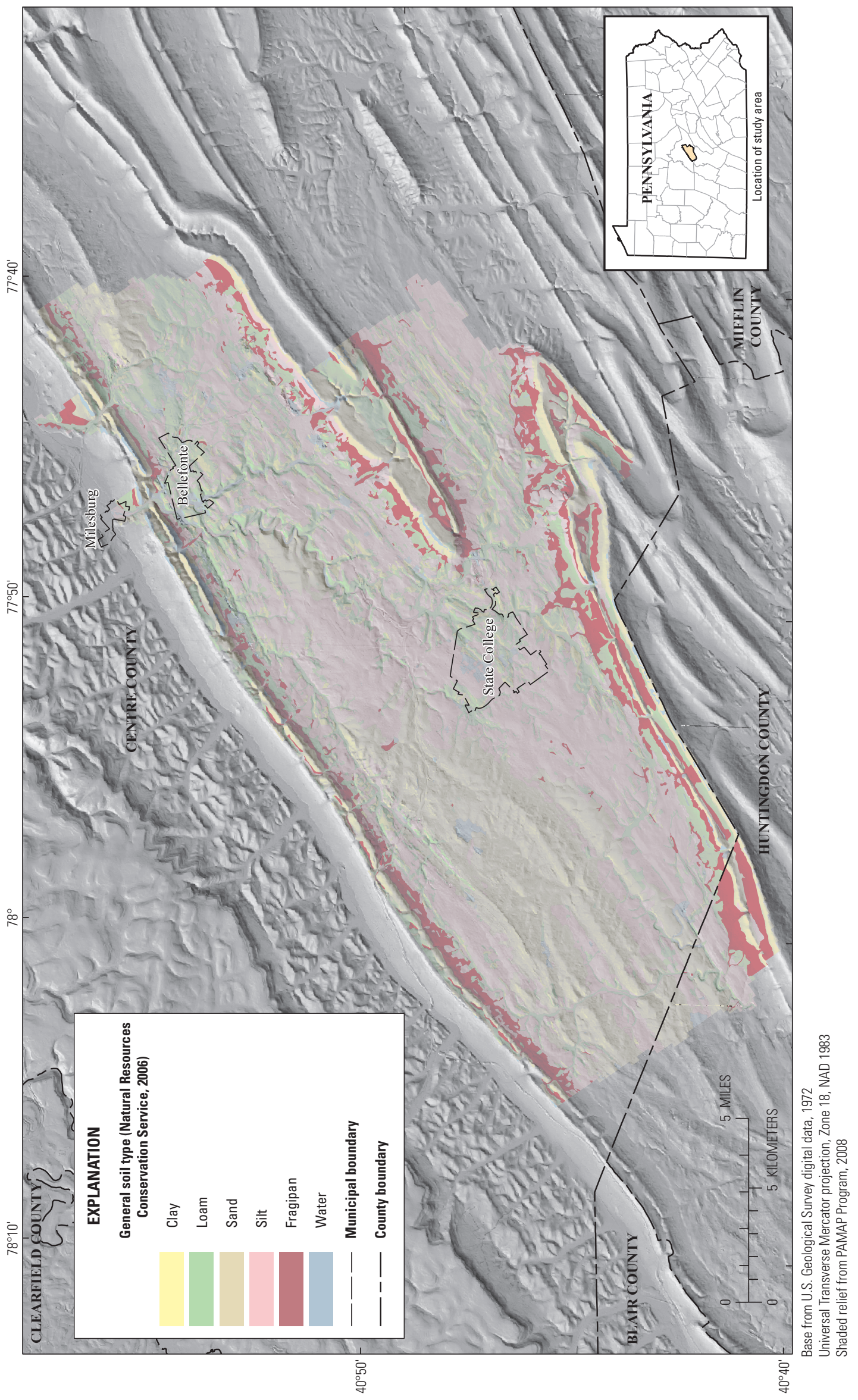

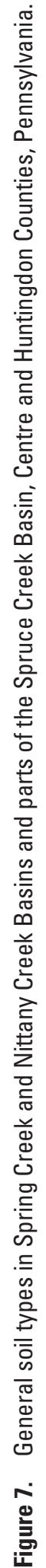




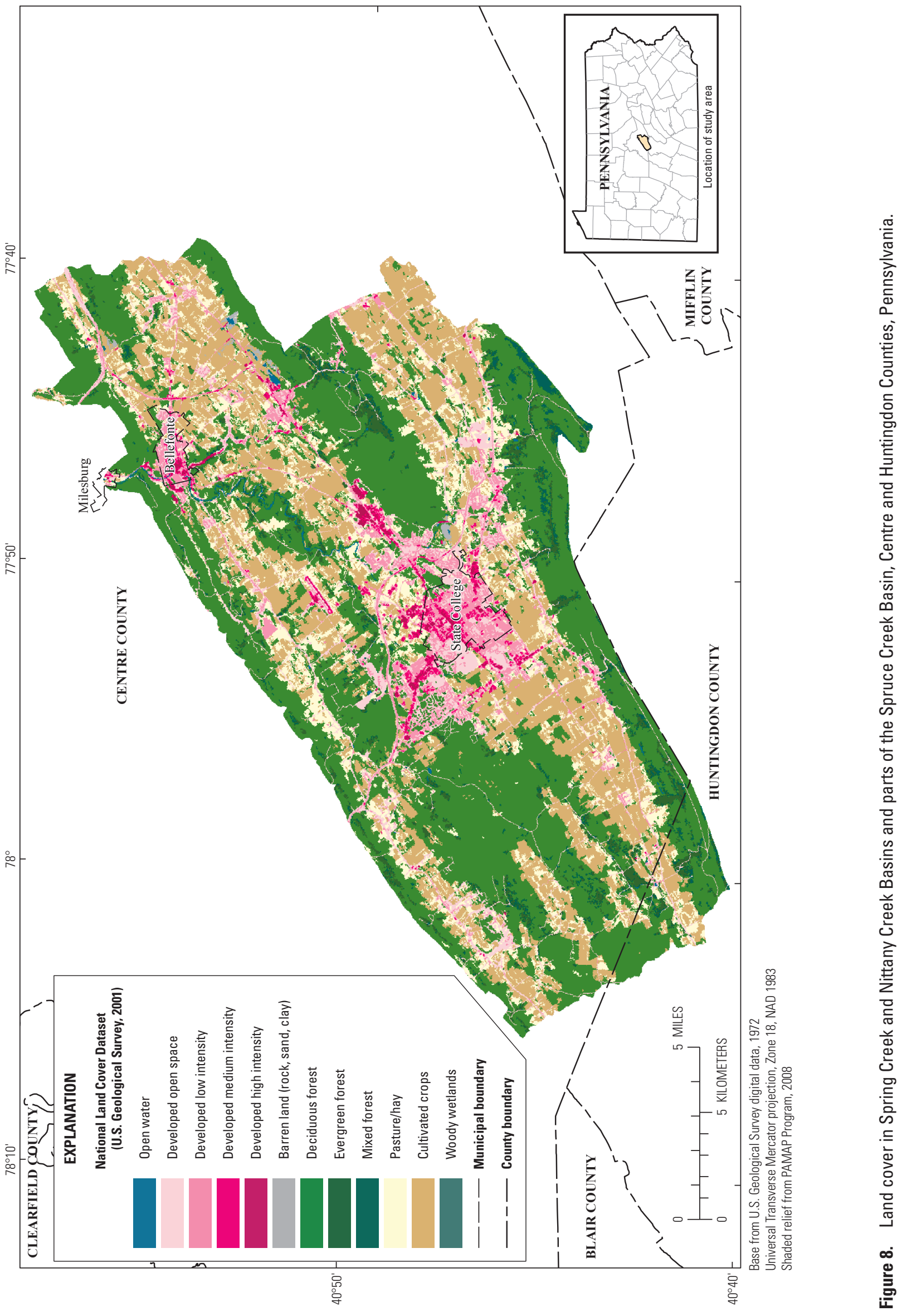




\section{Climate Data}

The forcing functions for PRMS are based on climate time-series data and include (1) precipitation, (2) maximum and minimum air temperatures, (3) potential evapotranspiration, and (4) solar radiation. Because GSFLOW operates in a daily mode only, the time-series data were organized by using daily time steps and provided as input to GSFLOW in climate-by-HRU (CBH) files, which have the same format as PRMS data files (Markstrom and others, 2008, p. 139-140).

Five CBH files were input, one for each climate-forcing type: daily precipitation, maximum air temperature, minimum air temperature, potential evapotranspiration, and actual solar radiation. The $\mathrm{CBH}$ files provided a value for each HRU for each day.

Precipitation data for meteorological stations were obtained from multiple sources, including 13 meteorological stations (table 2) in and near the modeled area. Data were acquired by using the Downsizer, a computer application that locates and downloads time-series data from environmental databases that are used to parameterize models such as PRMS (Ward-Garrison and others, 2009) and were augmented with data from the Pennsylvania State Climatologist office. The meteorological data were preprocessed by using an IDE weighting algorithm to generate the precipitation, minimum air temperature, and maximum air temperature $\mathrm{CBH}$ files for the simulation period. The IDE method distributes precipitation and maximum and minimum temperatures to each HRU using the closest climate-station elevations above and below a given HRU's elevation and linearly interpolates climate values for the HRU on the basis of the data from these two stations.

Wastewater effluent to the canopy has been included in the model from the Living Filter (Pennsylvania State University, 2012), which is a water re-use project that began in 1963 (figs. 1 and 2). Approximately 2.7 million gallons per day (Mgal/d) of wastewater from the Pennsylvania State University (PSU) is applied to approximately 600 acres of forests, croplands, and fields as tertiary treatment (Richardson, 2011). In addition to distributed precipitation (38.4 inches on average), approximately 62.4 inches of water per year (in/yr) related to reuse was added in GSFLOW to the application area to simulate the operation of the Living Filter.

Potential evapotranspiration was simulated by PRMS using a modified Jensen-Haise formulation (Markstrom and others, 2008, p. 43). Solar radiation was estimated by using computed daily clear-sky short-wave solar radiation for each HRU (Markstrom and others, 2008, p. 41-42). Modification of a degree-day method was used to compute actual solar radiation for each HRU (Markstrom and others, 2008, p. 42).

Table 2. Meteorological stations used to generate the climate data for the Precipitation-Runoff Modeling System-only simulations for Spring Creek and Nittany Creek Basins and parts of the Spruce Creek Basin, Centre and Huntingdon Counties, Pennsylvania.

[NAVD 88, North American Vertical Datum of 1988]

\begin{tabular}{llccc}
\hline $\begin{array}{c}\text { Station } \\
\text { number }\end{array}$ & \multicolumn{1}{c}{ Station name } & Latitude & Longitude & $\begin{array}{c}\text { Elevation, } \\
\text { in feet above } \\
\text { above NAVD 88 }\end{array}$ \\
\hline 361480 & Clarence & 41.049 & -77.941 & 1,390 \\
360482 & Beavertown 1 NE & 40.774 & -77.157 & 540 \\
360132 & Altoona & 40.523 & -78.369 & 1,280 \\
369022 & Tyrone & 40.664 & -78.219 & 890 \\
369714 & Williamsburg & 40.467 & -78.200 & 845 \\
365109 & Lock Haven Sewage Plant & 41.117 & -77.450 & 566 \\
364159 & Huntingdon & 40.515 & -78.003 & 685 \\
367409 & Renovo & 41.330 & -77.738 & 660 \\
368449 & State College & 40.793 & -77.867 & 1,170 \\
364992 & Lewistown & 40.587 & -77.570 & 460 \\
364853 & Laurelton Center & 40.902 & -77.214 & 800 \\
366921 & Philipsburg 2 S & 40.872 & -78.215 & 1,720 \\
365790 & Millheim & 40.884 & -77.474 & 1,120 \\
\hline
\end{tabular}




\section{PRMS-Only Model Calibration and Results}

Initial values of most PRMS parameters were computed by using methods documented by Viger and Leavesley (2007), Battaglin and others (1993), Jeton (2000), and Koczot and others (2005). Other parameters were estimated on the basis of GIS analysis, PRMS default values, and other datasets available for the modeled area. Initial parameter values were modified during the model calibration procedure by using manual and automated methods to minimize the difference between simulated and measured (or independently computed) potential evapotranspiration, solar radiation, and streamflow. Streamflow was recorded at USGS and CWC streamgages (fig. 4). Manual calibration methods were based on previous PRMS calibration experience and are summarized in table 3 .

The water budget components for the PRMS-only simulation were computed for water years 2000-06. To generate budgets for those years, the PRMS simulation period was initialized three years prior to WY 2000, which provided time for the simulated hydraulic system to adjust from the initial conditions that were assigned to the model. The major water budget components are summarized by water year in table 4 . During water years 2000-06, 2001 was the driest year and 2004 the wettest year on the basis of both simulated precipitation and runoff amounts.

The simulated mean infiltration rate for water years 2000-06 from PRMS was 14.7 inches per year (in/yr) for the basin as a whole. PRMS-derived infiltration (vertical flows from the PRMS soilzone) is a downward vertical flux that originates at the land surface. This process differs from gravity drainage (potential recharge from the PRMS soilzone by HRU) and recharge from the UZF Package to MODFLOW generated by GSFLOW, which is a vertical flux from the unsaturated zone to the saturated zone for each model cell.

Simulated mean infiltration rates ranged throughout the basin from approximately 2.1 to $72.9 \mathrm{in} / \mathrm{yr}$ (fig. 9). The greatest amount of infiltration was simulated in the carbonate-bedrock valley near the Living Filter, along Logan Branch, along the toe slopes of Nittany and Tussey Mountains, along the Gatesburg Ridge near the Scotia Barrens, along Buffalo Run and Spruce Creek, and in Penns Valley. The variation is attributed to the distribution of precipitation, variable slopes, and the runoff characteristics of land-use types in the study basin.

\section{MODFLOW-Only Model Development}

The finite-difference computer code MODFLOW-NWT (Niswonger and others, 2011) was used to simulate threedimensional (3D), steady-state, groundwater flow of the study basin. The MODFLOW-NWT model was constructed in units of meters and days. The length unit of meters was converted into feet for this report, resulting in some values that may seem unusual or may convey more precision than is warranted. MODFLOW-NWT is a code based on MODFLOW-2005 (Harbaugh, 2005) and includes a Newton solver that can be used to solve the groundwater-flow equation for situations where the fluctuating water table causes drying and rewetting of model cells (Hunt and Feinstein, 2012). A graphical user interface linked to Argus Numerical Environments was used for pre- and post-processing of data (Winston, 2000).

\section{Spatial and Temporal Discretization}

The study area was divided into a finite-difference grid (fig. 10) with three layers, 104 rows, and 216 columns. The horizontal dimensions of the cells were uniform 656 by 656 feet ( 200 by 200 meters) in horizontal dimension. The model grid was constructed with rows oriented N. $55^{\circ}$ E. to align with the general strike of geologic units in the area. The active model area coincides with the HRU boundary. The orientation of model rows along the strike of dipping units is important because fractures and solution openings that enhance permeability are better developed parallel to strike, and shaley beds tend to impede the movement of water across the strike of beds (Parizek and others, 1971, p. 40).

The steady-state MODFLOW-NWT model was based on water years 2000-06 and was assumed to represent the average groundwater conditions during that period. Recharge for initial simulations was assumed to be spatially uniform (calibration step 1, fig. 3), then was refined to use the average infiltration at each PRMS HRU for water years 2000-06 to represent a spatially varied recharge distribution (calibration step 2, fig. 3). Changes caused by seasonal variations in recharge or pumping were not simulated in the steady-state model but were incorporated in GSFLOW. For water years 2000-06, groundwater withdrawals, surface-water withdrawals, and discharges to surface water were varied by stress period on a monthly basis in GSFLOW.

\section{Boundary Conditions}

The elevation of the top of each cell in the uppermost model layer (layer 1) was set equal to the elevation of land surface determined as the mean of all data points from the USGS 30-meter DEM falling within the cell. The landsurface elevations assigned to model cells ranged from 680 to 2,399 feet, and the maximum elevation difference between adjacent cells was about $200 \mathrm{ft}$. The thickness of each model layer was set to a uniform value of 300 feet, so the total model thickness was 900 feet throughout the study area.

For this study, groundwater movement is assumed to be minimal below the base of the model $(900 \mathrm{ft}$ below land surface). The depth of active flow is not well known, but in Centre County, most high yielding zones in wells are generally encountered within weathered bedrock at depths of less than $400 \mathrm{ft}$ below land surface, and evidence of secondary permeability in limestone mines was almost entirely absent at depths greater than about $500 \mathrm{ft}$ (Wood, 1980, p. 31-32). Important water-bearing zones have been reported as deep as $600 \mathrm{ft}$ in production wells drilled in the Gatesburg Formation, and Parizek and others (1971, p. 61) hypothesized that groundwater flows at depths greater than 1,000 feet below land surface within the Dale Sandstone Member of the 


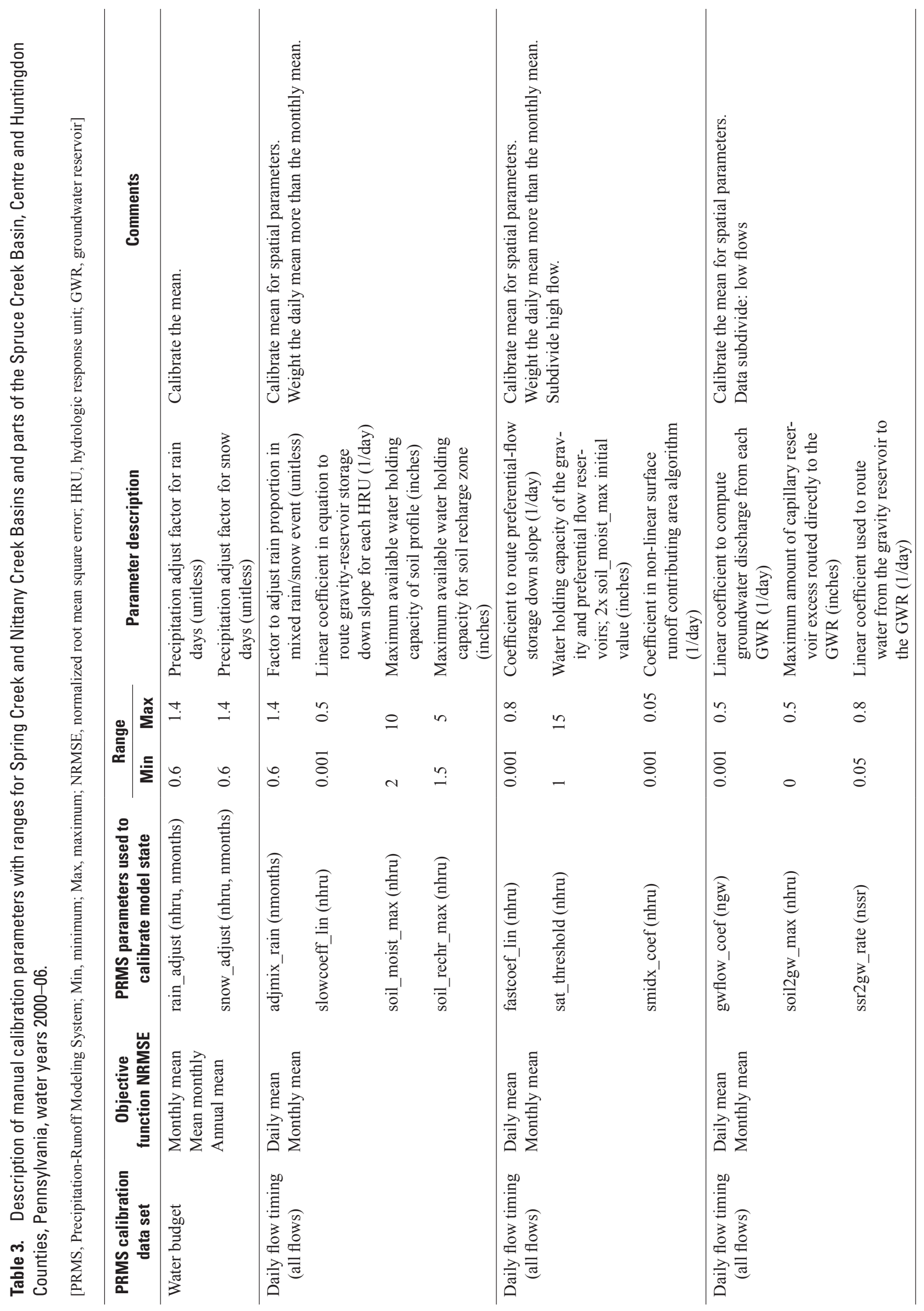


Table 4. Water budget components from the Precipitation-Runoff Modeling Systemonly simulation to generate the steady-state infiltration distribution for Spring Creek and Nittany Creek Basins and parts of the Spruce Creek Basin, Centre and Huntingdon Counties, Pennsylvania, water years 2000-06.

[in, inches; surface water and energy budgets simulated by using Precipitation-Runoff Modeling System (PRMS), Version 3.4050 2011-12-12; start time: 1996/10/01 00:00:00; end time: 2006/09/30 00:00:00; sum of hydrologic response unit (HRU) areas: 228.7 square miles ( $\mathrm{mi}^{2}$ ); active basin area: $228.7 \mathrm{mi}^{2}$; impervious basin area: $0.3 \mathrm{mi}^{2}$; pervious basin area: $228.4 \mathrm{mi}^{2}$ ]

\begin{tabular}{cccccc}
\hline $\begin{array}{c}\text { Water } \\
\text { year }\end{array}$ & $\begin{array}{c}\text { Precipitation } \\
\text { (in) }\end{array}$ & $\begin{array}{c}\text { Evapotranspiration } \\
\text { (in) }\end{array}$ & $\begin{array}{c}\text { Storage } \\
\text { (in) }\end{array}$ & $\begin{array}{c}\text { Simulated runoff } \\
\text { (in) }\end{array}$ & $\begin{array}{c}\text { Measured runoff } \\
\text { (in) }\end{array}$ \\
\hline 2000 & 35.008 & 26.786 & 1.314 & 10.782 & 10.935 \\
2001 & 30.946 & 22.412 & 2.779 & 7.056 & 9.511 \\
2002 & 39.666 & 28.228 & 4.139 & 10.057 & 10.437 \\
2003 & 55.849 & 31.678 & 6.446 & 21.822 & 15.138 \\
2004 & 58.629 & 34.406 & 6.434 & 24.191 & 20.548 \\
2005 & 34.732 & 21.813 & 1.265 & 18.058 & 16.571 \\
2006 & 44.189 & 27.586 & 3.338 & 14.502 & 11.891 \\
\hline
\end{tabular}

Bellefonte Dolomite. However, for the purpose of simulating basin-wide surface-water and groundwater budgets, accounting for groundwater down to $900 \mathrm{ft}$ below land surface is probably sufficient.

\section{Lateral Boundaries}

The lateral extent of the modeled area was defined with no-flow, general-head, and specified-head boundaries (fig. 10). No-flow (inactive) cells were placed around the perimeter of the modeled area except (1) along the topographic divide separating Halfmoon Creek (within the Spruce Creek Basin) from Warriors Mark Run (outside of the modeled area), which was simulated by the use of a general-head boundary, and (2) along the divide separating Cedar Run (within the Spring Creek Basin) from Penns Creek Basin (outside of the modeled area), which was simulated by the use of specified heads (fig. 10).

No-flow cells prohibit transfer of water across Bald Eagle Mountain to the northwest and Tussey Mountain to the southeast. No-flow cells also follow topographic divides separating parts of study basin from Penns Creek, Little Fishing Creek, and Lick Run Basins to the east and northeast.

General-head cells allow a transfer of groundwater across the topographic divide between Halfmoon Creek and Warriors Mark Run Basins. The general-head boundary allows groundwater within the carbonate rocks to cross the divide and move out of the modeled area to discharge to Warriors Mark Run, owing to its lower elevation and the high permeability of the carbonate rocks. The magnitude of the flow is related to the difference between the elevation of the groundwater levels simulated by the model at the general-head boundary and the reference elevations assigned to Warriors Mark Run, and to the hydraulic conductance between those locations. Reference elevations were determined by temporarily extending the model grid to Warriors Mark Run, simulating groundwater flow paths from the divide to the creek, and assigning reference values to the divide equal to the elevation of the flow path terminus where groundwater discharged to Warriors Mark Run.

Specified-head cells separating parts of the Cedar Run and Penns Creek watersheds also allow the transfer of water across the divide in the carbonate-rock units. The direction and magnitude of flow depend upon the difference between the groundwater levels specified at the boundary and adjacent cells. Groundwater levels along the boundary of the Spring Creek model were set to the elevation of the water table mapped by Taylor (1997).

\section{Infiltration from Precipitation}

Groundwater recharge (water reaching the water table) is customarily assigned in the recharge $(\mathrm{RCH})$ package of MODFLOW-NWT. In this study, however, the PRMS routine in GSFLOW computes infiltration through the root zone from each HRU, passing that flux to the UZF package of MODFLOW-NWT. Recharge to the water table is computed in the UZF package, so the RCH package is not needed. Thus, the MODFLOW-NWT model was constructed by assigning the spatially variable distribution of average infiltration to the UZF package that was derived from PRMS simulations for water years 2000-06. The infiltration rate from PRMS, simulated as the sum of PRMS vertical fluxes from the soil zone from each HRU (fig. 9), is assigned as infiltration to 


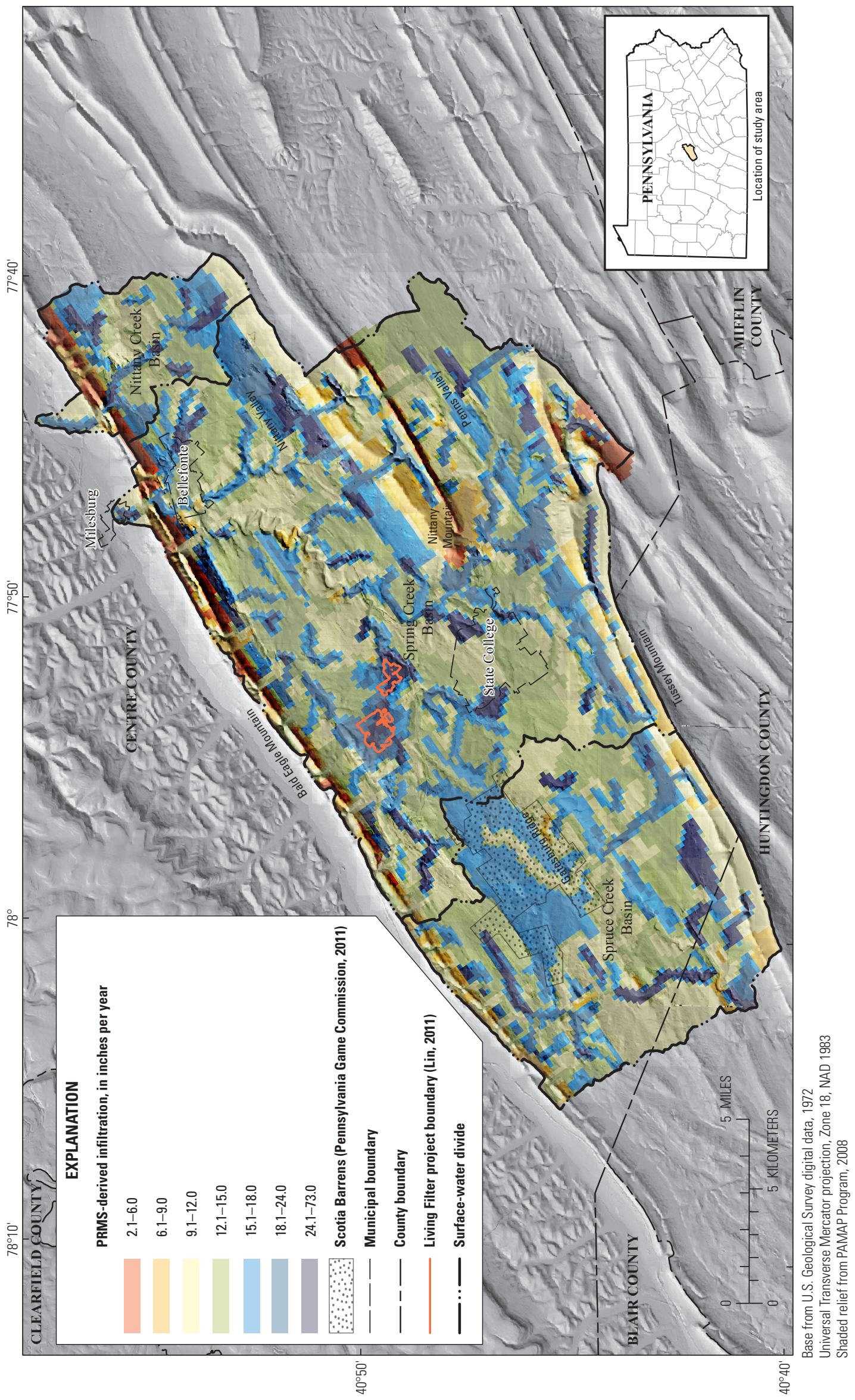

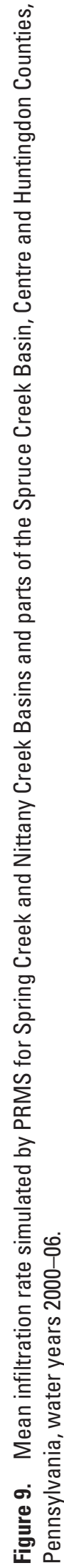




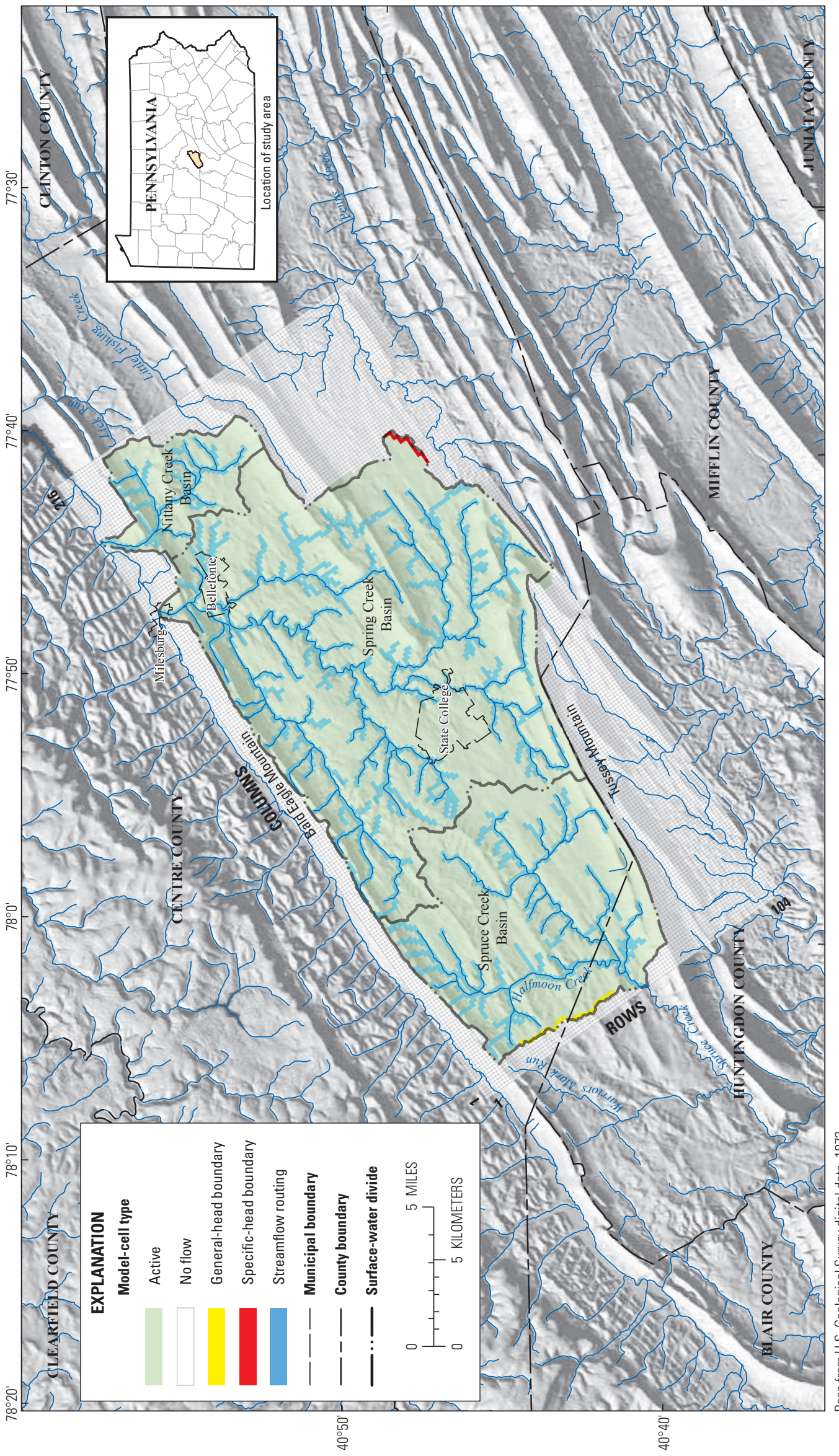

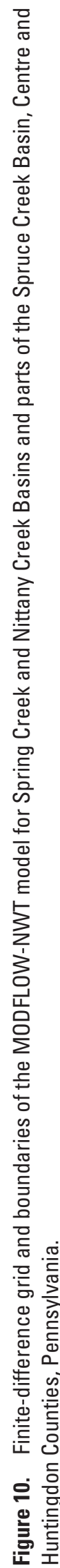


MODFLOW cells on the basis of the percentage of each HRU in the cell. The simulated rate of infiltration averaged $14.7 \mathrm{in} / \mathrm{yr}$ for the study basin and ranged from about 2.1 to $72.9 \mathrm{in} / \mathrm{yr}$.

The average infiltration rate for the study basin of $14.7 \mathrm{in} / \mathrm{yr}$ is slightly less than the amount needed to provide the base flow computed at the USGS streamflow-gaging station 01547100 Spring Creek near Milesburg. During water years $2000-06$, average base flow determined by the local minimum method of hydrograph separation (Pettyjohn and Henning, 1979) by use of the HYSEP program (Sloto and Crouse, 1996) was 196 cubic feet per second $\left(\mathrm{ft}^{3} / \mathrm{sec}\right)$. Recharge of $15.2 \mathrm{in} / \mathrm{yr}$ is needed to provide this base flow, assuming a contributing groundwater basin of $175 \mathrm{mi}^{2}$.

\section{Streams}

Streamflow is simulated by using the SFR2 package (Niswonger and Prudic, 2005), which allows streams to gain or lose water and accounts for the flow in each stream cell so that losses cannot exceed the simulated streamflow. Streams were represented in model layer 1 by 387 segments made up of 3,444 reaches (fig. 10). Unsaturated flow beneath the streams was also simulated. The elevation of the top of the streambed in each SFR reach was assigned $3.28 \mathrm{ft}(1 \mathrm{~m})$ less than the nearest elevation derived from the USGS 10-meter DEM and was adjusted to insure that the streambed elevation always decreased downstream. Thickness of the streambed was set to $3.28 \mathrm{ft}$ for all stream segments. Stream width was varied by segment from 3.3 to $66 \mathrm{ft}$ on the basis of 39 locations where the stream width was measured in the field. Hydraulic conductivity of the streambed was assigned an initial value of 2 feet per day (ft/d) on non-carbonate rocks and $13.1 \mathrm{ft} / \mathrm{d}$ on carbonate rocks, which are based on the approximate difference in the horizontal hydraulic conductivity between the non-carbonate and carbonate rocks; hydraulic conductivity was adjusted during model calibration. Stream slope for each segment was determined as the difference between the upstream and downstream elevations divided by segment length. Unsaturatedzone properties beneath all stream reaches were set to constant values. Vertical hydraulic conductivity was set equal to the vertical hydraulic conductivity of layer 1 beneath the stream, and the saturated water content was set equal to 0.03 .

Water was added at the upstream end of stream segments in the SRF2 package to simulate major wastewater discharges to streams from municipalities and industry. Water was subtracted from SFR2 segments to simulate major withdrawals from streams for water supply and other uses. Simulated discharges to streams totaled about $20.5 \mathrm{ft}^{3} / \mathrm{sec}$, and withdrawals from streams totaled about $9.4 \mathrm{ft}^{3} / \mathrm{sec}$ (fig. 11 and table 5). Wastewater discharge from PSU is a source of recharge. It was not included in the steady-state MODFLOW-NWT simulation but was included in the GSFLOW model. The average withdrawal from Roaring Run (fig. 2) of about 330,000 gallons per day by the State College Borough Water Authority (SCBWA) was not simulated because the withdrawal is from a reservoir that was not included in the model. Without the reservoir, simulated streamflow was insufficient to supply a withdrawal of this magnitude, so the model, as constructed for this study, is not designed to accurately simulate flow in Roaring Run.

\section{Wells}

Forty-five groundwater withdrawals were simulated by the steady-state model using the multi-node well (MNW) package (Halford and Hanson, 2002). Wells were used to represent groundwater withdrawals from 5 mines and 40 production wells totaling about $14.5 \mathrm{Mgal} / \mathrm{d}$ (fig. 12 and table 6). Wells were incorporated into the model to represent the mean withdrawals during water years 2000-06 from the PSU and SCBWA production wells, along with other water purveyors with withdrawals greater than 50 gallons per minute (gal $/ \mathrm{min})$. The average withdrawal rate was assigned to each well for the steady-state simulation, and the MNW package computed the contribution from each model layer on the basis of the transmissivity and groundwater levels in each layer.

Table 5. Discharges to streams and withdrawals from streams simulated by using the Streamflow-Routing Package of MODFLOW-NWT model for Spring Creek and Nittany Creek Basins and parts of the Spruce Creek Basin, Centre and Huntingdon Counties, Pennsylvania.

$\left[\mathrm{m}^{3} / \mathrm{d}\right.$, cubic meters per day; Mgal/d, million gallons per day; $\mathrm{ft}^{3} / \mathrm{s}$, cubic feet per second; WWTP, wastewater treatment plant; UAJA, University Area Joint Authority; TWP, township]

\begin{tabular}{lccc}
\hline \multirow{2}{*}{ Identifier } & \multicolumn{3}{c}{ Rate } \\
\cline { 2 - 4 } & $\mathbf{m}^{3} / \mathbf{d}$ & Mgal/d & $\mathbf{f t}^{3} \mathbf{s}$ \\
\hline \multicolumn{2}{c}{ Wastewater } & discharges & to \\
\hline Hanson & 1,750 & 0.46 & 0.72 \\
Corning & 3,540 & 0.94 & 1.45 \\
Bellefonte WWTP & 10,721 & 2.83 & 4.38 \\
Graymont Mine & 14,030 & 3.71 & 5.73 \\
UAJA WWTP & 20,150 & 5.32 & 8.24 \\
Total discharge & 50,191 & 13.26 & 20.51 \\
\hline \multicolumn{1}{c}{ Withdrawals ${ }^{2}$ from streams in model layer 1 } \\
\hline Diamond Spring & 78 & 0.02 & 0.03 \\
Elks Country Club & 414 & 0.11 & 0.17 \\
College Twp Spring & 1,075 & 0.28 & 0.44 \\
Bellefonte Borough & 21,450 & 5.67 & 8.77 \\
Total withdrawal & 23,017 & 6.08 & 9.41 \\
\hline
\end{tabular}

${ }^{1}$ Penn State University wastewater is discharged as a land application, so it is not included in the list of surface-water discharges.

${ }^{2}$ The average withdrawal of 330,000 gallons per day from Roaring Run is not simulated in the model. 


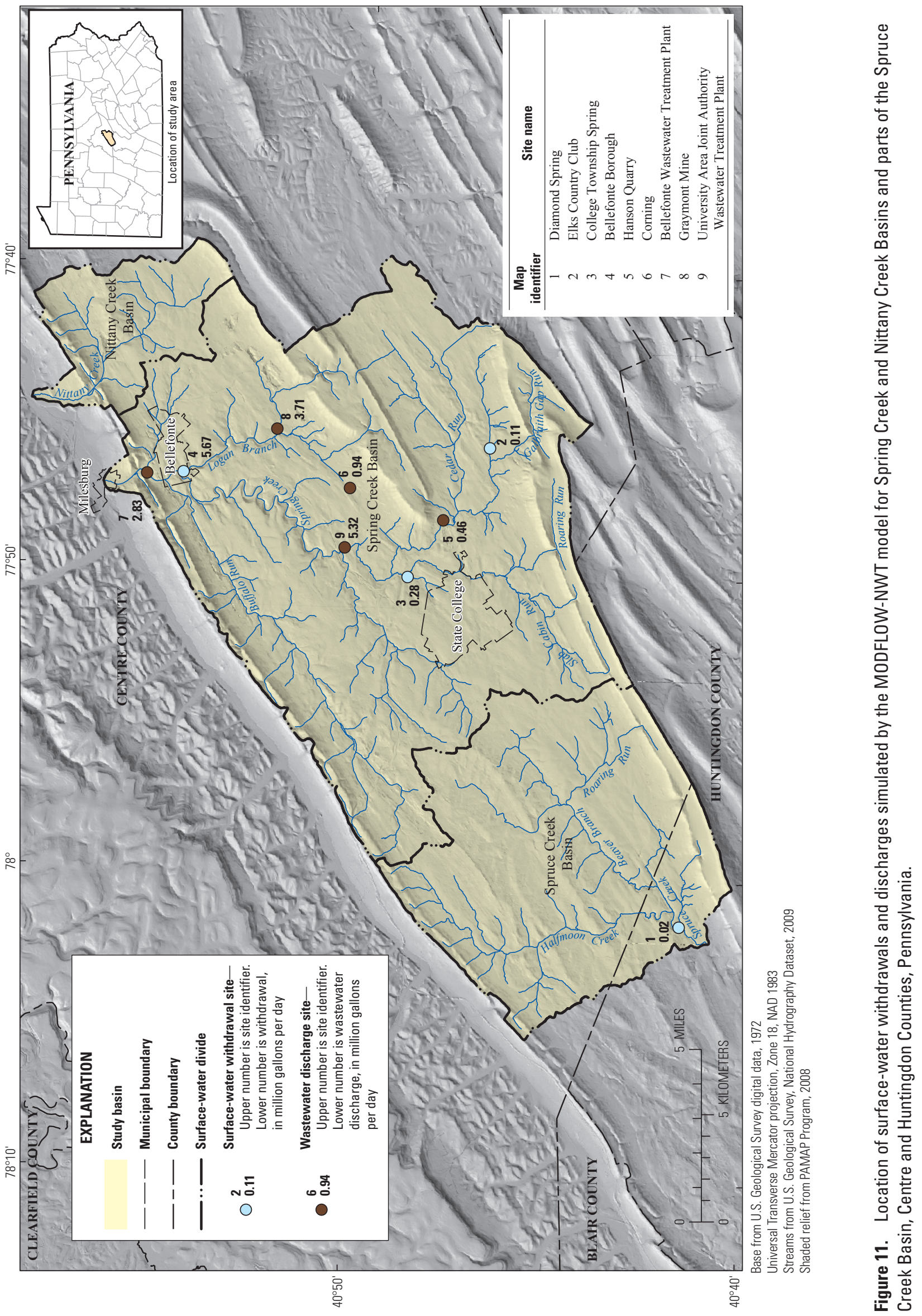




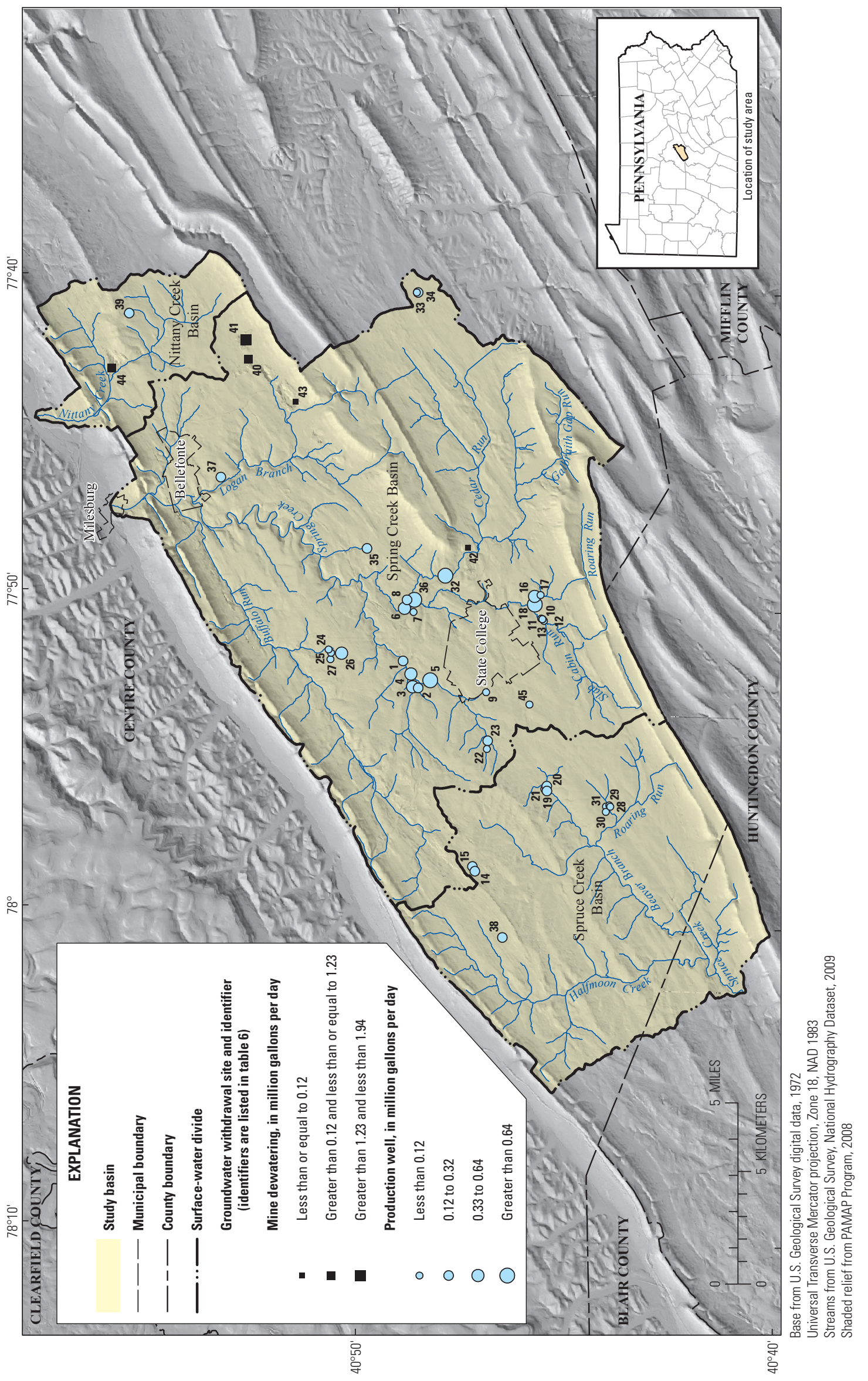

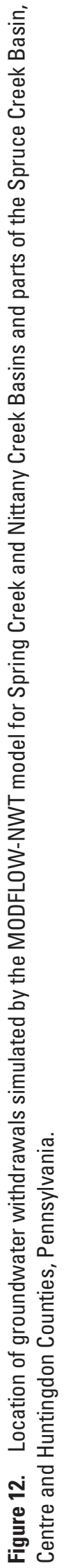


Table 6. Groundwater withdrawals simulated using the MODFLOW-NWT steady-state model for Spring Creek and Nittany Creek Basins and parts of the Spruce Creek Basin, Centre and Huntingdon Counties, Pennsylvania.

$\left[\mathrm{m}^{3} / \mathrm{d}\right.$, cubic meters per day; Mgal $/ \mathrm{d}$, million gallons per day; $\mathrm{ft}^{3} / \mathrm{s}$, cubic feet per second]

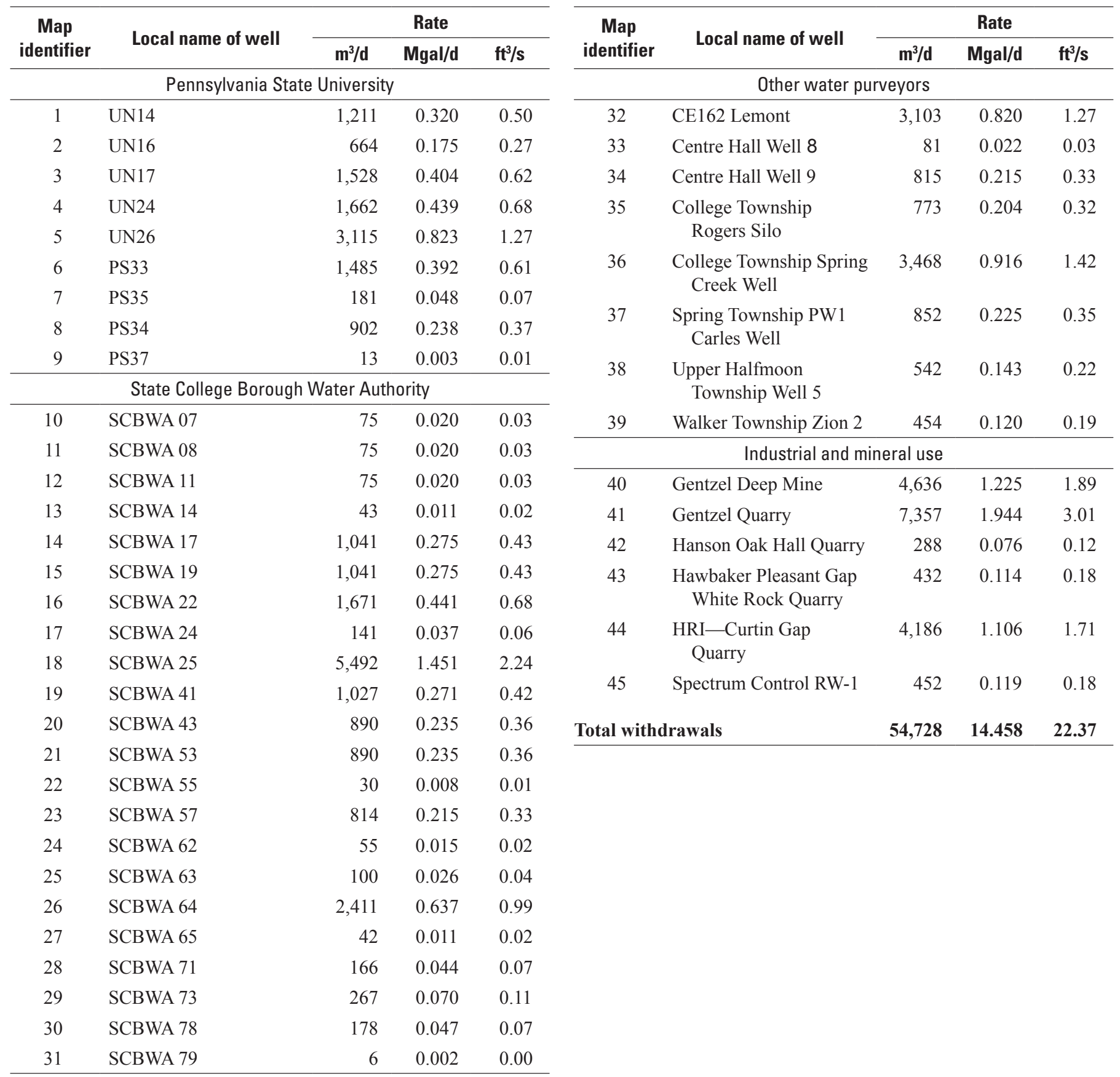




\section{Evapotranspiration}

Evapotranspiration from groundwater was simulated with the UZF package. A potential evapotranspiration rate of $25.5 \mathrm{in} / \mathrm{yr}$ was used, as computed for State College by Waltman and others (1997, p. 217) using a modified Thornthwaite approach. An extinction depth of $6.56 \mathrm{ft}$ ( 2 meters) below land surface was assumed. When linked to the GSFLOW model, the potential evapotranspiration (PET) from MODFLOWNWT is replaced by values for each HRU simulated by PRMS on the basis of daily climate conditions. Actual evapotranspiration is computed in GSFLOW as the sum of each component of evapotranspiration (ET) in the sequence (1) canopy storage evaporation, (2) sublimation, (3) impervious storage evaporation, (4) evapotranspiration in the PRMS soilzone, and (5) transpiration below the PRMS soilzone. The available evapotranspiration at each step is the unsatisfied PET not used by other ET components (canopy-storage evaporation, sublimation, impervious-storage evaporation, transpiration, and soil-storage evaporation) after the previous computation step.

\section{Aquifer Properties}

Aquifer properties were assigned by parameters in the Upstream Weighting (UPW) Package (Niswonger and others, 2011) of the steady-state MODFLOW-NWT model to represent the horizontal hydraulic conductivity $(\mathrm{K})$ along model rows, ratio of horizontal to vertical hydraulic conductivity (VANI), and ratio of hydraulic conductivity along model columns (dip direction of bedding) to hydraulic conductivity along model rows - the strike direction of bedding (HANI). Parameters for specific yield and specific storage also were specified for use in the transient GSFLOW model but were not needed for the MODFLOW-NWT steady-state simulation.

Ten parameters were used in the UPW package to represent the spatial distribution of hydraulic conductivity for the geologic units in the study area. Six parameters represent the groups of geologic units shown in table 7 (at end of report). Groupings of geologic units with similar hydraulic conductivity were based on previous studies, particularly the geologic mapping (fig. 5) and relative rankings by Parizek and Filey (1982) in table 7. Two additional parameters were used to represent zones of high horizontal hydraulic conductivity not restricted to a particular geologic unit. The parameter Kfract represents a zone of high hydraulic conductivity along the western margin of carbonate rocks in the Spring Creek Valley, and ThomK represents a similar zone of hypothesized high hydraulic conductivity near Thompson Run. Horizontal and vertical anisotropy with respect to hydraulic conductivity were assigned by parameters HANIcarb and VANI. Initially, all sandstone and shale units were assigned a hydraulic conductivity of $0.66 \mathrm{ft} / \mathrm{d}(0.2 \mathrm{~m} / \mathrm{d})$, and carbonate rocks were assigned $9.8 \mathrm{ft} / \mathrm{d}(3 \mathrm{~m} / \mathrm{d})$; then the values were adjusted during the model-calibration procedure.
Values of hydraulic conductivity for all parameters, except those representing the Mines Dolomite and upper sandy members of the Gatesburg Formation (Kgates), were assumed to decrease with depth because few high yielding fractures were reported below 300 feet, except in the Gatesburg Formation (Wood, 1980, p. 31). Values assigned to parameters in layer 1 were reduced in layer 2 by a factor of 0.2 for shale units and 0.7 for carbonate units. The hydraulic conductivity for all units in layer 3 was reduced by a factor of 0.04 from layer 1 values.

The ratio of horizontal to vertical hydraulic conductivity is specified by the parameter VANI, which was assigned a value of 1.0 for all geologic units in all layers. Its value was changed during model calibration only in a small area near Bellefonte, Pa., to control the quantity of groundwater discharge to the lower reaches of Logan Branch and Spring Creek. The ratio of hydraulic conductivity along model rows (along strike) to that along model columns (across strike) is specified by the parameter HANI. The value of HANI was adjusted during model calibration. Its value was computed as a base value multiplied by a factor ranging from 0.1 to 1.0 that represented the approximate effect of dipping beds on HANI. The factor was small for beds dipping steeply in the direction of model columns and was 1.0 for horizontal beds.

\section{MODFLOW-Only Model Steady-State Calibration and Results}

Aquifer properties in the MODFLOW-NWT model were adjusted by use of the parameter-estimation program UCODE2005 (Poeter and others, 2005) and by trial and error. Values of hydraulic conductivity and horizontal anisotropy were adjusted by trying to match observations of average, steadystate, groundwater levels and computed base flow during water years 2000-06. The sources of groundwater levels and base flows used as observations for model adjustments are given in table 8. Locations of the wells used for groundwaterlevel data are shown in figure 13, and locations of streamgages used for base-flow computations are shown in figure 4 .

Groundwater-level observation data came from multiple sources. For wells with multiple groundwater levels, the mean value of the observations during water years 2000-06 was used. Groundwater levels from Taylor (1997) represent the largest synoptic dataset of groundwater levels, but they were measured during 1994, prior to the calibration period of this model. Regardless, because of its large areal coverage, the dataset was used, but the values were assigned a small weighting factor in the regression.

Base-flow observations used to adjust the model were either the base flow at a streamgage or the base-flow gain between two stations (table 9). Mean base-flow values for water years 2000-06 were computed for the local minimum 
Table 8. Sources of streamflow data and groundwater levels used to adjust aquifer properties in the MODFLOW-NWT steady-state model for Spring Creek and Nittany Creek Basins and parts of the Spruce Creek Basin, Centre and Huntingdon Counties, Pennsylvania.

[USGS, U.S. Geological Survey; USFWS, U.S. Fish and Wildlife Service; CWC, ClearWater Conservancy; SCBWA, State College Borough Water Authority; SRBC, Susquehanna River Basin Commission; NAWS, North American Water Systems; PSU, Penn State University; C, Continuous; D, Daily; CMP, Continuous with missing periods; P, Periodic; S, Single observations; --, none; X, missing record]

\begin{tabular}{|c|c|c|c|c|c|}
\hline $\begin{array}{c}\text { Streamgage name for stations used } \\
\text { to compute base flow or source of } \\
\text { groundwater levels }\end{array}$ & $\begin{array}{l}\text { Station } \\
\text { abbreviation }\end{array}$ & Agency & $\begin{array}{c}\text { Type of } \\
\text { observation }\end{array}$ & $\begin{array}{l}\text { Missing } \\
\text { record }\end{array}$ & Period of record \\
\hline \multicolumn{6}{|c|}{ Streamflow data } \\
\hline Spring Creek at Houserville, PA & SPH & USGS & $\mathrm{C}$ & -- & 10/1999-09/2006 \\
\hline Spring Creek near Axemann, PA & SPA & USGS & $\mathrm{C}$ & -- & 10/1999-09/2006 \\
\hline Spring Creek at Milesburg, PA & SPM & USGS & $\mathrm{C}$ & -- & $10 / 1999-09 / 2006$ \\
\hline Spruce Creek at Graysville, PA & SPG & USFWS and USGS & $\mathrm{D}$ & $\mathrm{X}$ & 10/1999-09/2006 \\
\hline $\begin{array}{l}\text { Slab Cabin Run at Rt. } 26 \text { at Lemont, PA } \\
\text { (Slab Cabin Run Lower) }\end{array}$ & SLL & CWC & $\mathrm{C}$ & $\mathrm{X}$ & 10/1999-09/2006 \\
\hline $\begin{array}{l}\text { Cedar Run at Oak Hall, PA (Cedar Run } \\
\text { Lower) }\end{array}$ & CEL & CWC & $\mathrm{C}$ & $\mathrm{X}$ & 10/1999-09/2006 \\
\hline $\begin{array}{l}\text { Spring Creek at Oak Hall, PA (Spring } \\
\text { Creek Upper) }\end{array}$ & SPU & $\mathrm{CWC}$ & $\mathrm{C}$ & $\mathrm{X}$ & 10/1999-09/2006 \\
\hline $\begin{array}{l}\text { Buffalo Run near Bellefonte, PA (Buffalo } \\
\text { Run Lower) }\end{array}$ & BUL & $\mathrm{CWC}$ & $\mathrm{C}$ & $\mathrm{X}$ & 10/1999-09/2006 \\
\hline $\begin{array}{l}\text { Logan Branch near Pleasant Gap, PA } \\
\text { (Logan Branch Upper) }\end{array}$ & LOU & CWC & $\mathrm{C}$ & $\mathrm{X}$ & 10/1999-09/2006 \\
\hline $\begin{array}{l}\text { Logan Branch above Big Spring at } \\
\text { Bellefonte, PA (Logan Branch Lower) }\end{array}$ & LOL & CWC & $\mathrm{C}$ & $\mathrm{X}$ & 02/2005-09/2006 \\
\hline $\begin{array}{l}\text { Thompson Run near State College, PA } \\
\text { (Thompson Run Lower) }\end{array}$ & THL & PSU & $\mathrm{C}$ & -- & 2007 \\
\hline \multicolumn{6}{|c|}{ Groundwater-level data } \\
\hline 7 observation wells & -- & CWC and USGS & CMP & -- & 10/1999-09/2006 \\
\hline 33 domestic-supply wells & -- & NAWS & $\mathrm{P}$ & -- & 01/1999-06/2005 \\
\hline 9 unused supply wells & -- & SCBWA & $\mathrm{P}$ & -- & 01/2003-12/2004 \\
\hline 180 domestic-supply wells & -- & SRBC & S & -- & October 1994 \\
\hline 28 domestic-supply wells & -- & USGS & S & -- & 1984 \\
\hline
\end{tabular}




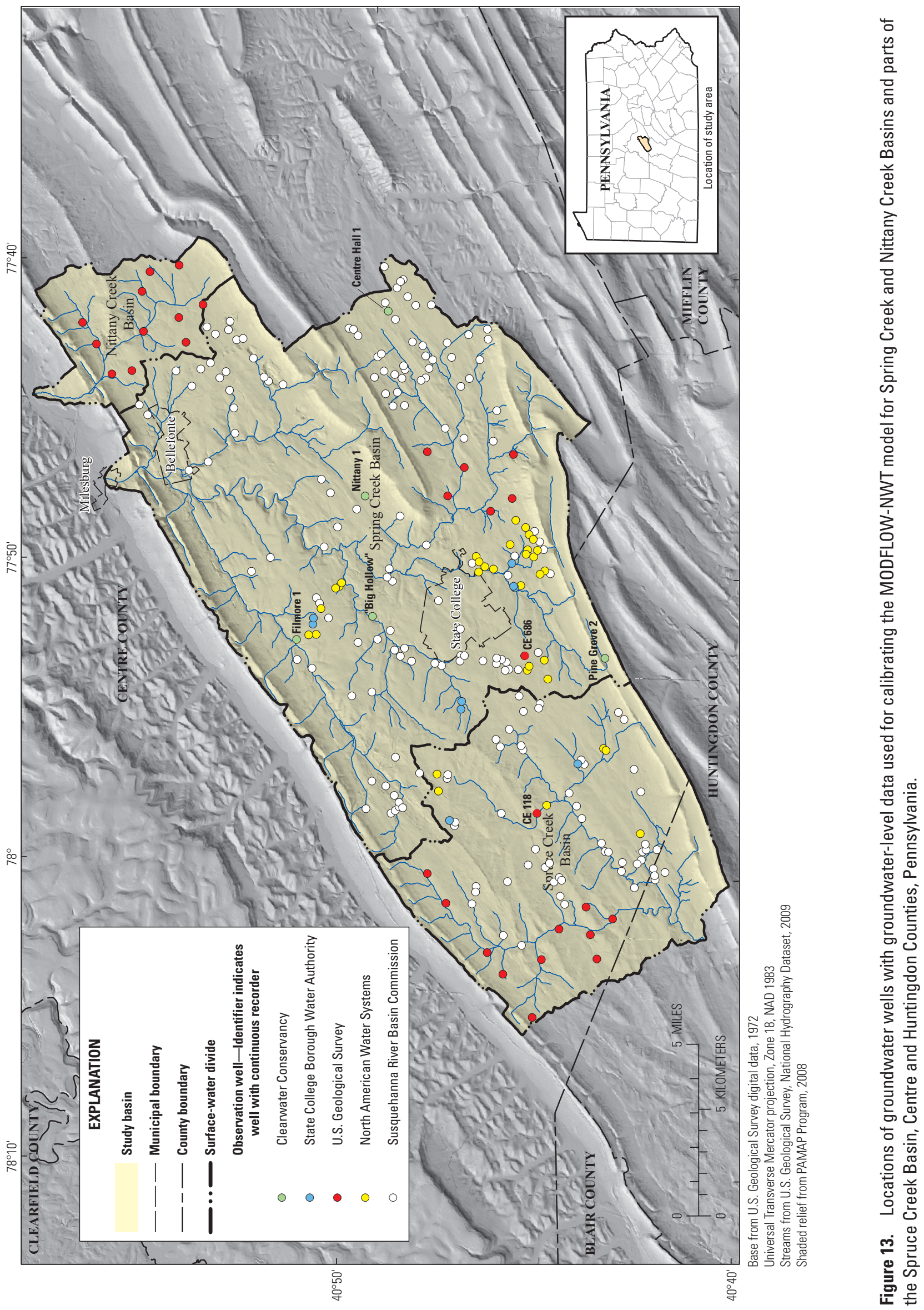


Table 9. Base-flow values and weights used to adjust the MODFLOW-NWT steady-state model for Spring Creek and Nittany Creek Basins and parts of the Spruce Creek Basin, Centre and Huntingdon Counties, Pennsylvania.

[ft, feet; $\mathrm{ft}^{3} / \mathrm{s}$, cubic feet per second]

\begin{tabular}{|c|c|c|c|}
\hline Station name ${ }^{1}$ & $\begin{array}{c}\text { Station } \\
\text { abbreviation }\end{array}$ & $\begin{array}{l}\text { Base-flow value } \\
\left(\mathrm{ft}^{3} / \mathrm{s}\right)\end{array}$ & $\begin{array}{l}\text { Weighting value } \\
{\left[\quad\left[\mathrm{ft} /\left(\mathrm{ft}^{3} / \mathrm{s}\right)\right]\right.}\end{array}$ \\
\hline Thompson Run Lower & THL & 4.9 & 55.7 \\
\hline Cedar Run Lower & CEL & 16.0 & 17.1 \\
\hline Logan Run Upper & LOU & 21.0 & 13.0 \\
\hline Spring Creek Upper & SPU & 19.0 & 14.4 \\
\hline Logan Run Lower & LOL & 76.0 & 3.6 \\
\hline Slab Cabin Run Lower & SLL & 10.7 & 25.5 \\
\hline Spruce Creek at Graysville, PA & SPG & 38.0 & 5.4 \\
\hline Spring Creek at Houserville, PA & $\mathrm{SPH}$ & 55.3 & 11.9 \\
\hline Buffalo Run Lower & BUL & 14.0 & 19.5 \\
\hline $\begin{array}{l}\text { Spring Creek_-gain between Houserville and } \\
\text { Axemann streamgages }\end{array}$ & AXE_GAIN & 32.0 & 6.4 \\
\hline $\begin{array}{l}\text { Logan Branch-between Upper and Lower } \\
\text { streamgages }\end{array}$ & LOL_GAIN & 55.0 & 2.7 \\
\hline $\begin{array}{l}\text { Spring Creek-gain in main stem below streamgages } \\
\text { near Axemann, PA and at Milesburg, PA }\end{array}$ & MILES_GAIN & 20.0 & 10.3 \\
\hline
\end{tabular}

method (Pettyjohn and Henning, 1979) by use of the HYSEP program (Sloto and Crouse, 1996). Because the streamflow record was not complete for some of the stations, daily streamflow values were estimated by using MISTE (MIssing STreamflow Estimation), a tool for estimating missing daily discharge values that relies on daily values that have been determined for other (index) sites (U.S. Geological Survey, 2003). The program uses stepwise regression analysis to correlate daily discharge data at the study site with daily discharge data from one or more index sites.

\section{Weighting of Observations}

A weighting factor was used in the parameter-estimation program UCODE to adjust observations to account for the difference in units between groundwater levels and base flows, and to incorporate differences in the perceived accuracy of observations. Weights for groundwater levels were assigned different values depending upon the accuracy of the measuring point elevation and frequency of groundwater-level observations. Groundwater levels measured once were assigned a lower weight than groundwater levels measured continuously and recorded for the study period. Weights assigned to groundwater levels ranged from 0.69 feet for discrete observations at 180 domestic-supply wells to 4.3 feet for the average groundwater level for the study period at seven observation wells with continuous recorders. Weights for base-flow observations relied on the estimated accuracy of the streamflow record compiled by USGS, CWC, and others, as described in Hill and Tiedeman (2007, p. 291). All base-flow weights were then increased by a factor of 100 to yield weighted residuals that were in the same range as the groundwater-level residuals. The greater weights increased the weighted residuals and importance of the base-flow observations in the parameter estimation process. The base-flow weighting values are shown in table 9. 


\section{Adjusted Aquifer Properties}

Aquifer properties were adjusted during model calibration, and the final values for each parameter are given in table 10. Horizontal hydraulic conductivity zones for layers 1 to 3 are illustrated in figures 14,15 , and 16 , and values for areas of horizontal anisotropy applicable to all layers are shown in figure 17. The storage properties of the aquifer-specific storage and specific yield-were not adjusted during steady-state MODFLOW-NWT simulations because those parameters were not applicable. Storage properties were needed for transient GSFLOW simulations, so they were adjusted from their initial assigned values during GSFLOW calibration. Specific storage was initially assigned a value of $0.3048 \mathrm{E}-6$ per foot (1.0 E-6 per meter) in all layers; the initial distribution of specific-yield values is illustrated in figures 18 and 19.

During model calibration, results were not sensitive (composite scaled sensitivity of less than 0.4 ) to the ratio of horizontal to vertical hydraulic conductivity (VANI) so its value was set to 1.0 and was only adjusted beneath the lower reaches of Spring Creek and Logan Run. For example, beneath Spring Creek, VANI was increased to 100; and beneath Logan Run, it was decreased to 0.01 in order to increase the groundwater discharge to Logan Run in a reach of known large stream gains and to reduce the simulated discharge to Spring Creek near Houserville.

To simulate the groundwater trough along the northwestern side of the study basin, a zone of large hydraulic conductivity was inserted into layer 2 (parameter Kfract in table 10 and fig. 15) to depress simulated groundwater levels in the area of the trough. The axis of the trough trends northeastsouthwest, parallel to model rows. Formation of the trough has been explained as an expression of a zone of large hydraulic conductivity associated with the Birmingham Thrust Fault (Siddiqui, 1969, p. 404; Parizek and others, 1971, p. 36). The water-table configuration simulated by the model is shown in figure 20. An area of large hydraulic conductivity was also simulated in layer 1 near Thompson Run (parameter ThomK in table 10 and fig. 14) to allow the groundwater flow to discharge to that stream in quantities indicated by the streamgage.

Spatial differences in hydraulic conductivity with depth are illustrated in a section across the study basin along model column 119 at the nose of Nittany Mountain (fig. 21). Note the decrease in hydraulic conductivity with depth and the large hydraulic conductivity cell in layer 2 representing the highly permeable fracture (shown in red).

\section{Comparison of Simulated and Observed Steady-State Groundwater Levels and Base Flows}

Steady-state groundwater levels simulated by the model were compared to groundwater levels from 257 wells (fig. 22). There is considerable scatter associated with the data. The root mean squared difference (RMSD) is $43 \mathrm{ft}$, and RMSD normalized to the range of groundwater-level observations is 5.1 percent. About 72 percent of the simulated groundwater
Table 10. Adjusted values and sensitivities of parameters used in the steady-state MODFLOW-NWT model for Spring Creek and Nittany Creek Basins and Parts of the Spruce Creek Basin, Centre and Huntingdon Counties, Pennsylvania.

\begin{tabular}{|c|c|c|}
\hline $\begin{array}{c}\text { Formation } \\
\text { parameter name }\end{array}$ & $\begin{array}{c}\text { Adjusted value of } \\
\text { horizontal hydraulic } \\
\text { conductivity along rows } \\
\text { (feet/day) }\end{array}$ & $\begin{array}{l}\text { Composite scaled } \\
\text { sensitivity }\end{array}$ \\
\hline Kshale & 0.26 & 1.2 \\
\hline Kcarb & 9.0 & 1.8 \\
\hline Kgates & 61.0 & 2.4 \\
\hline Knit & 33.1 & 1.9 \\
\hline Kfract & 1,417 & 3.9 \\
\hline Kaxe_ston & 3.4 & 0.69 \\
\hline ThomK & 1,247 & 1.9 \\
\hline LemontK & 60.4 & 1.6 \\
\hline $\begin{array}{c}\text { Formation } \\
\text { parameter name }\end{array}$ & $\begin{array}{l}\text { Adjusted ratio of } \\
\text { horizontal anisotropy along } \\
\text { columns to along rows } \\
\text { (dimensionless) }\end{array}$ & $\begin{array}{l}\text { Composite scaled } \\
\text { sensitivity }\end{array}$ \\
\hline HANIcarb & 0.33 & 2.78 \\
\hline
\end{tabular}

levels were within $40 \mathrm{ft}$ of the observed values. However, for the wells with surveyed measuring points [levels provided by Spring Creek Watershed Community (SCWC), N.A. Water Systems, and SCBWA], 96 percent of the residuals were less than $40 \mathrm{ft}$. Simulated groundwater levels were lower than observed levels at 39 percent of the observations, so the model more frequently simulated levels that were too high rather than too low. Simulated groundwater levels with the greatest error tended to be those for single groundwater-level observations from the Susquehanna River Basin Commission (SRBC) and USGS sources. Those observations were historical in nature made many years prior to the simulation period and, for the SRBC sources, were only approximately located on the land surface. For these reasons, observations from those datasets were assigned low weights in the overall parameter estimation.

Steady-state base-flow values simulated by the model were compared to base flows computed from streamflow at 16 sites in figure 23 . Three of the 16 base-flow values were for the base-flow gains between streamgages on Spring Creek. The simulated values are biased low and are less than the base-flow estimates at most locations. The low values of simulated base flow were caused by an insufficient application of infiltration to the unsaturated zone (UZF package) of the MODFLOW-NWT model. Because the infiltration was derived from output of the calibrated PRMS model, infiltration values were not increased in MODFLOW. The infiltration rates were estimated independently during calibration of the coupled GSFLOW model. 


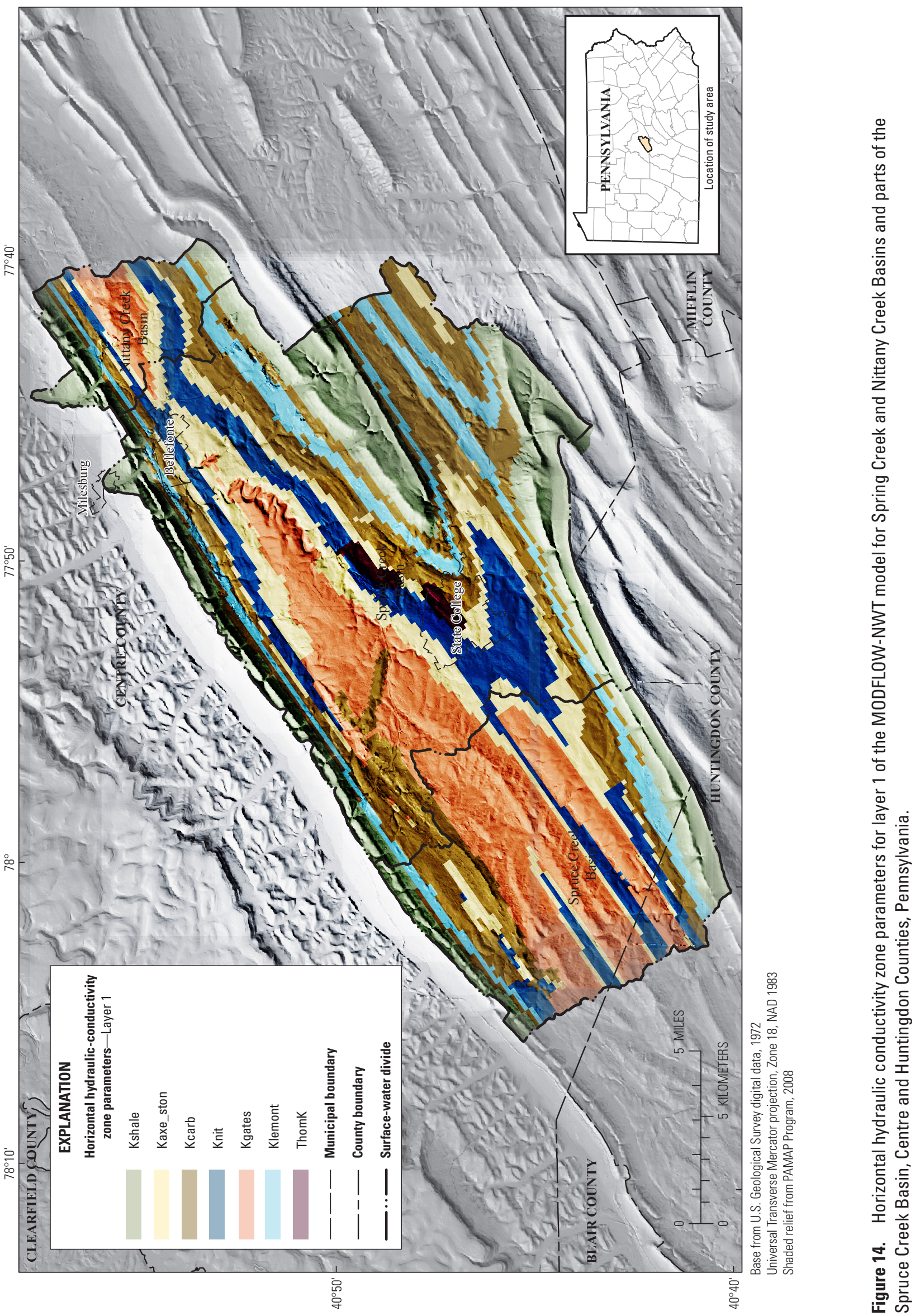




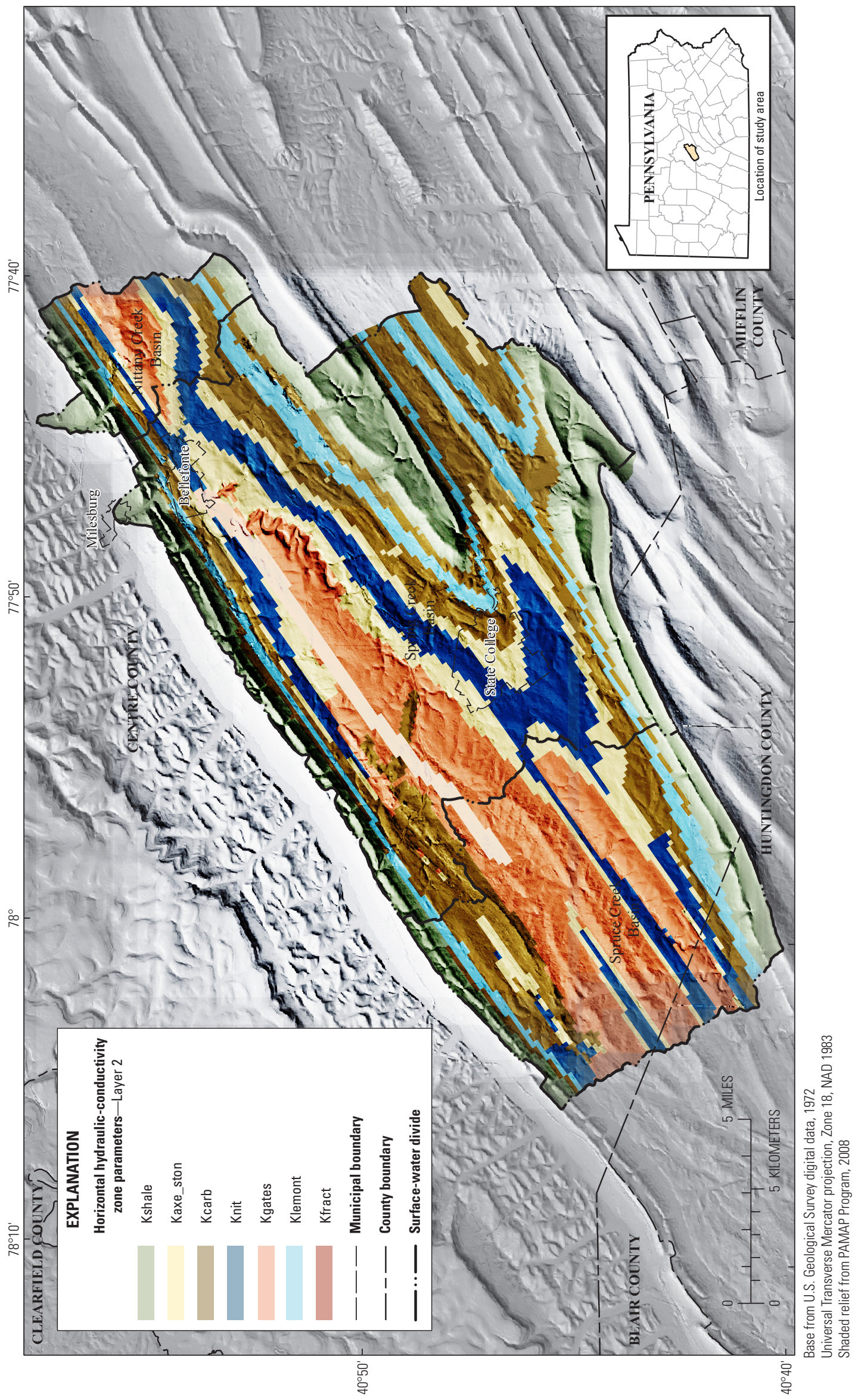

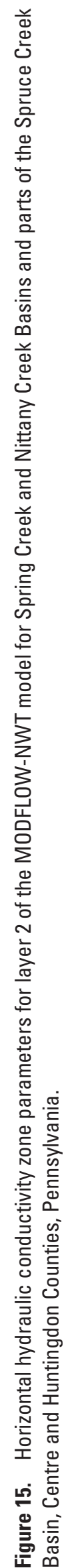




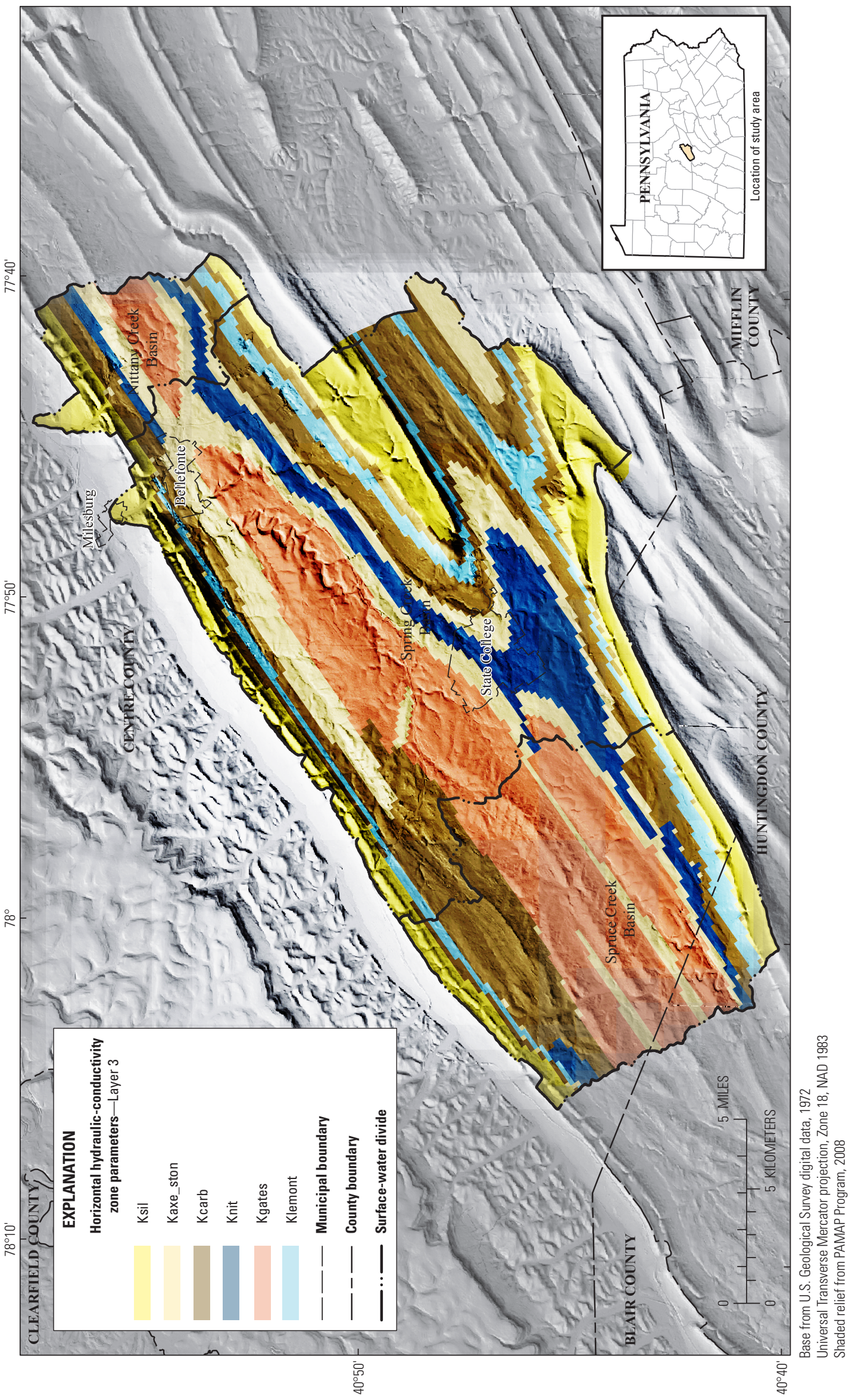

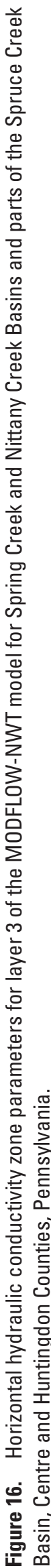




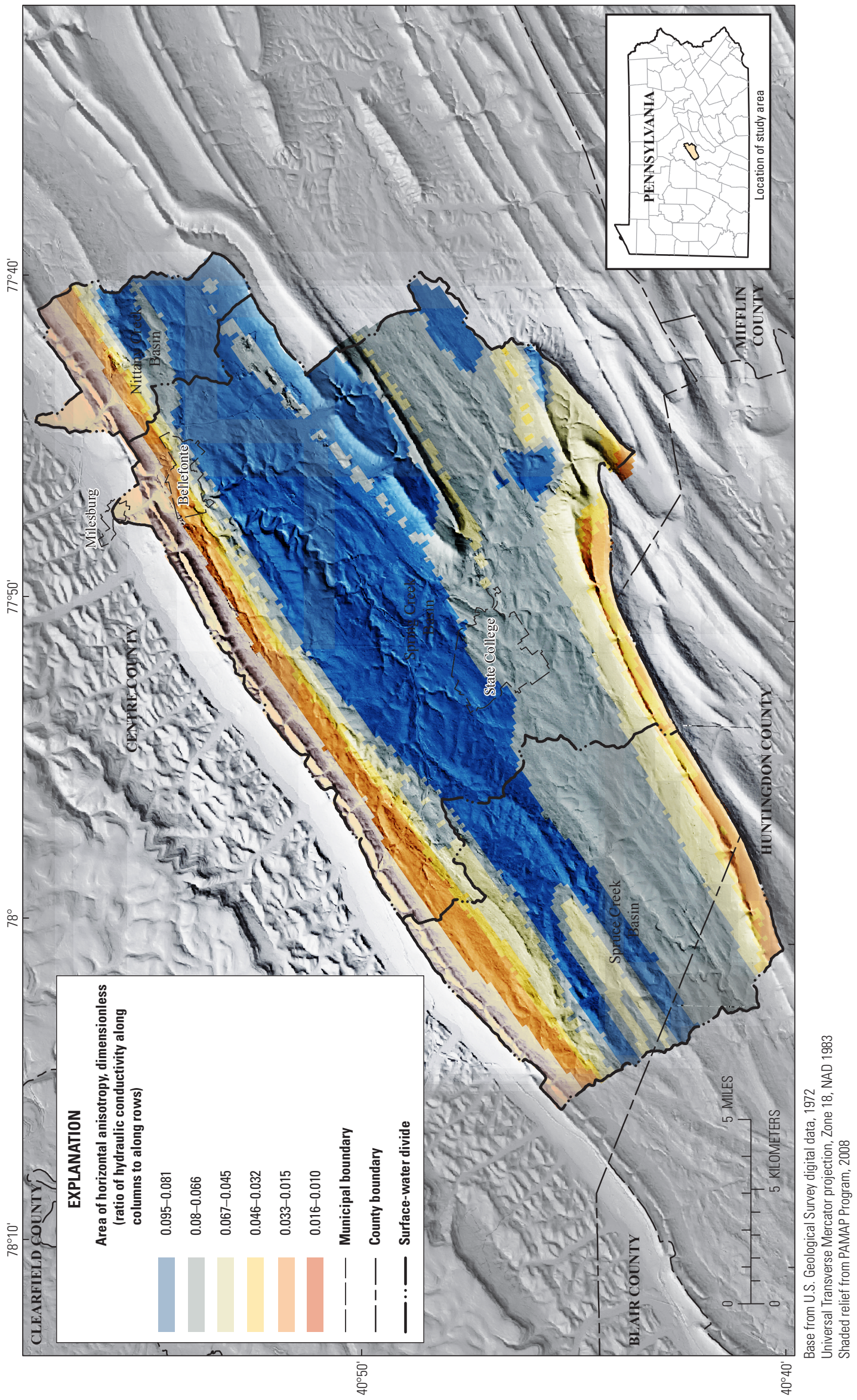

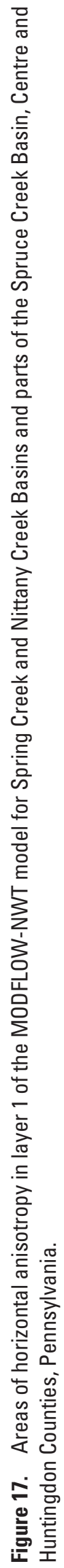




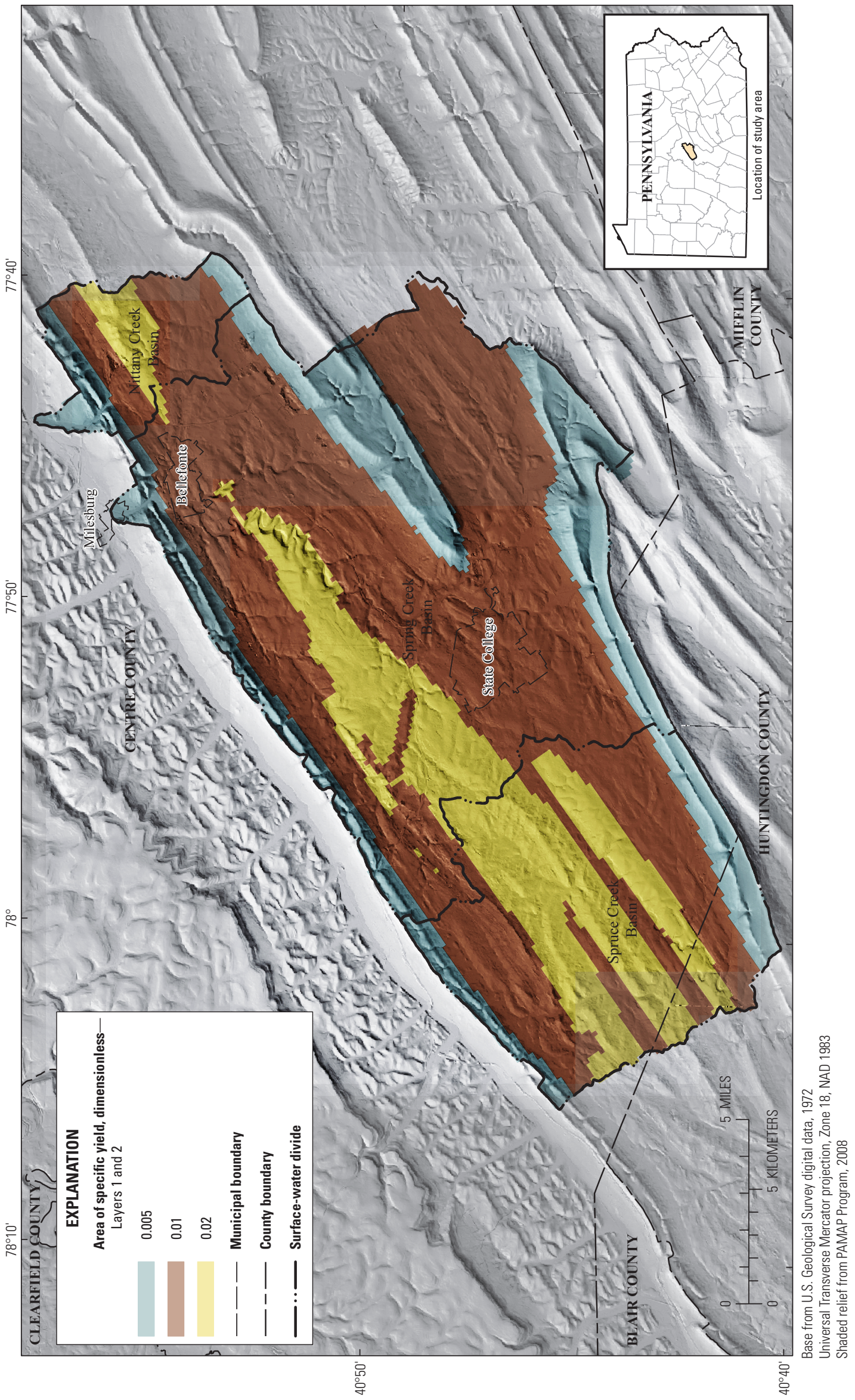

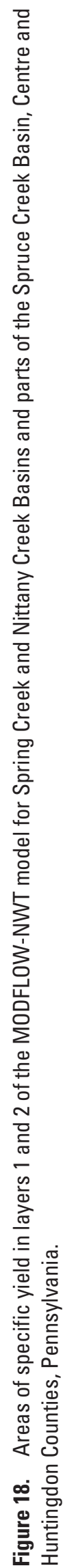




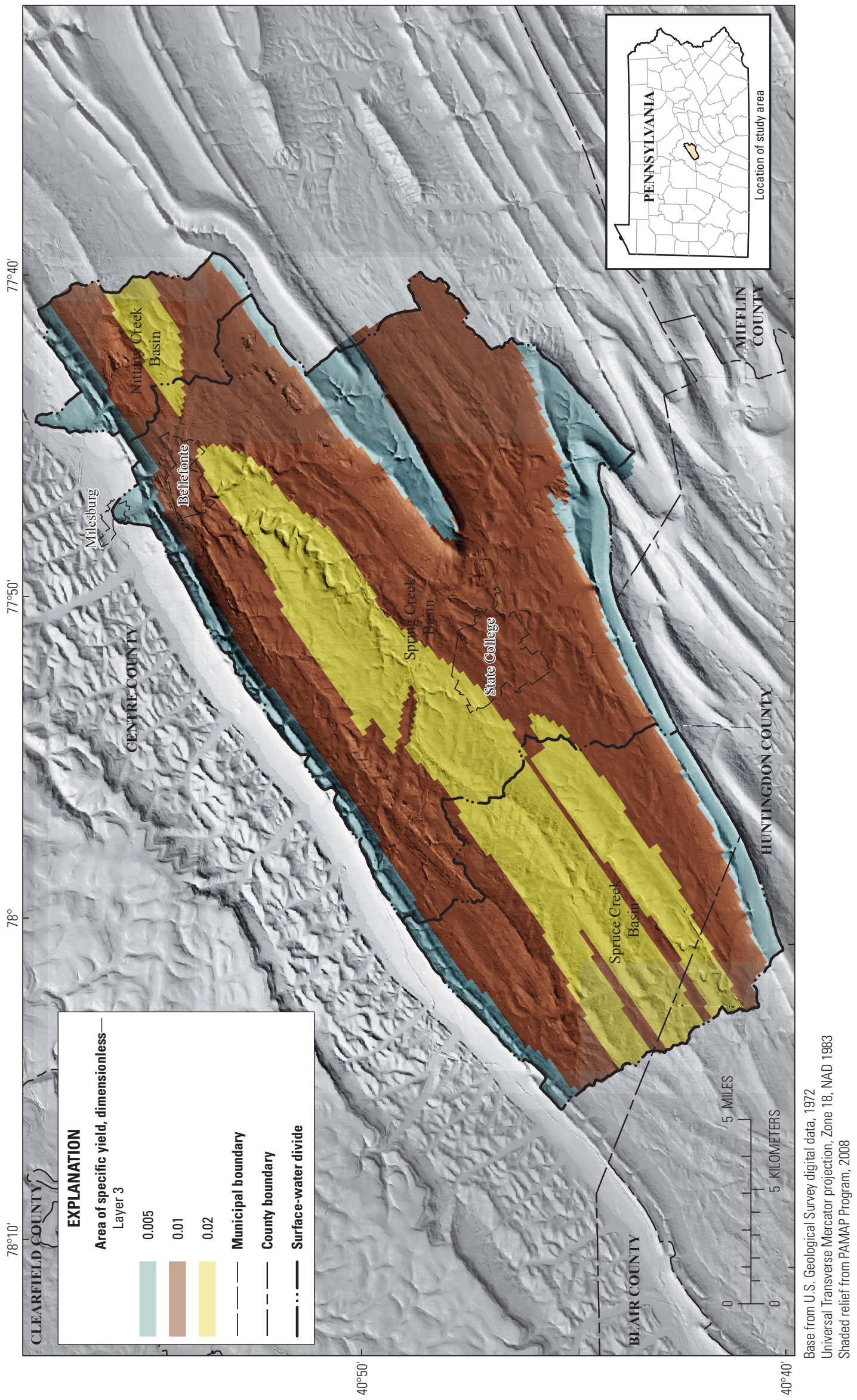

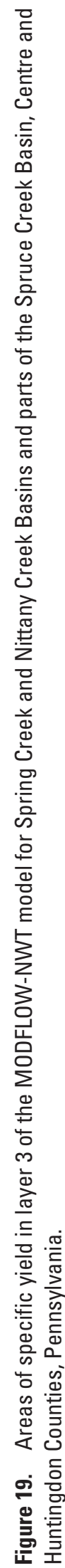




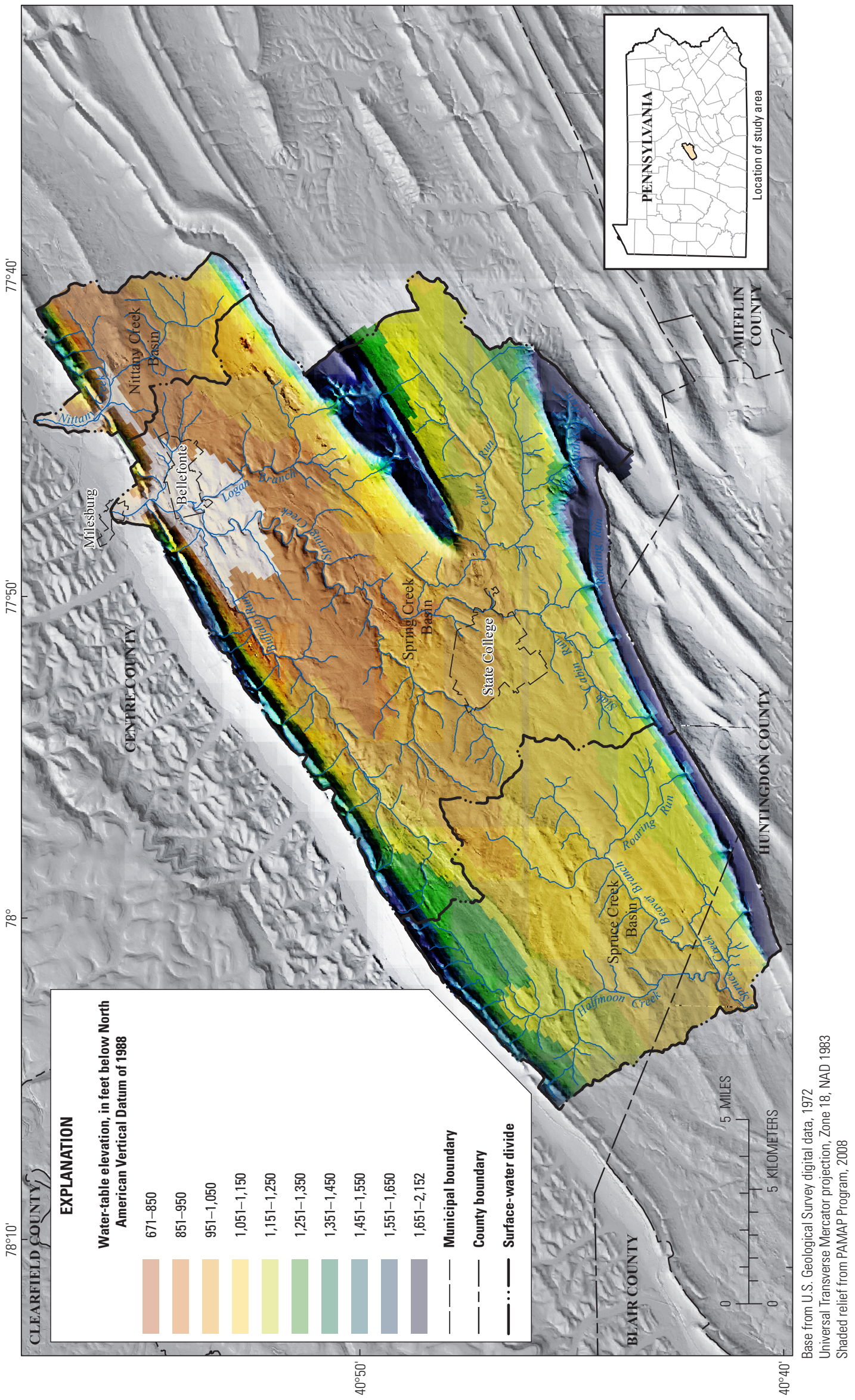

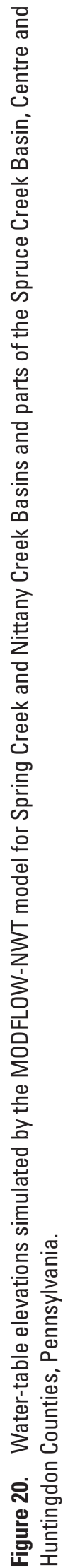




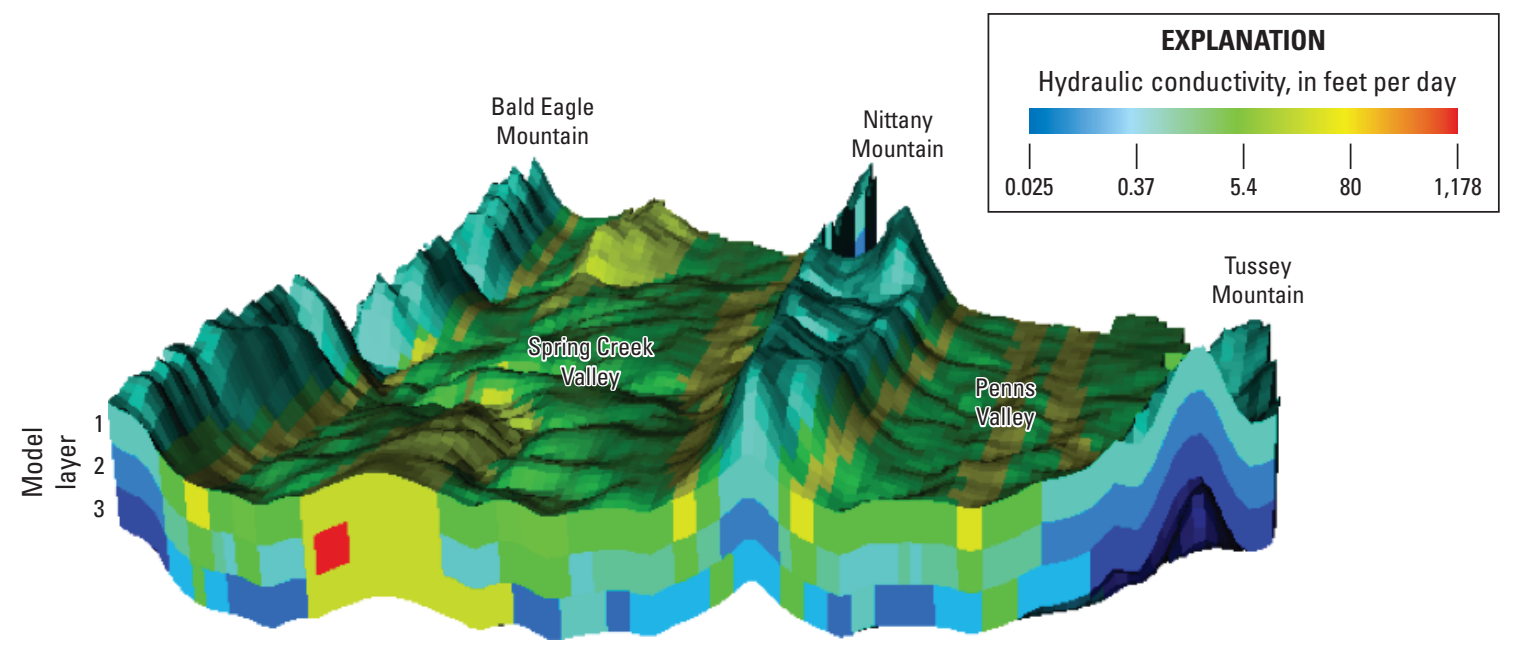

Figure 21. Hydraulic conductivities through column 119 of the MODFLOW-NWT model for Spring Creek and Nittany Creek Basins and parts of the Spruce Creek Basin, Centre and Huntingdon Counties, Pennsylvania.
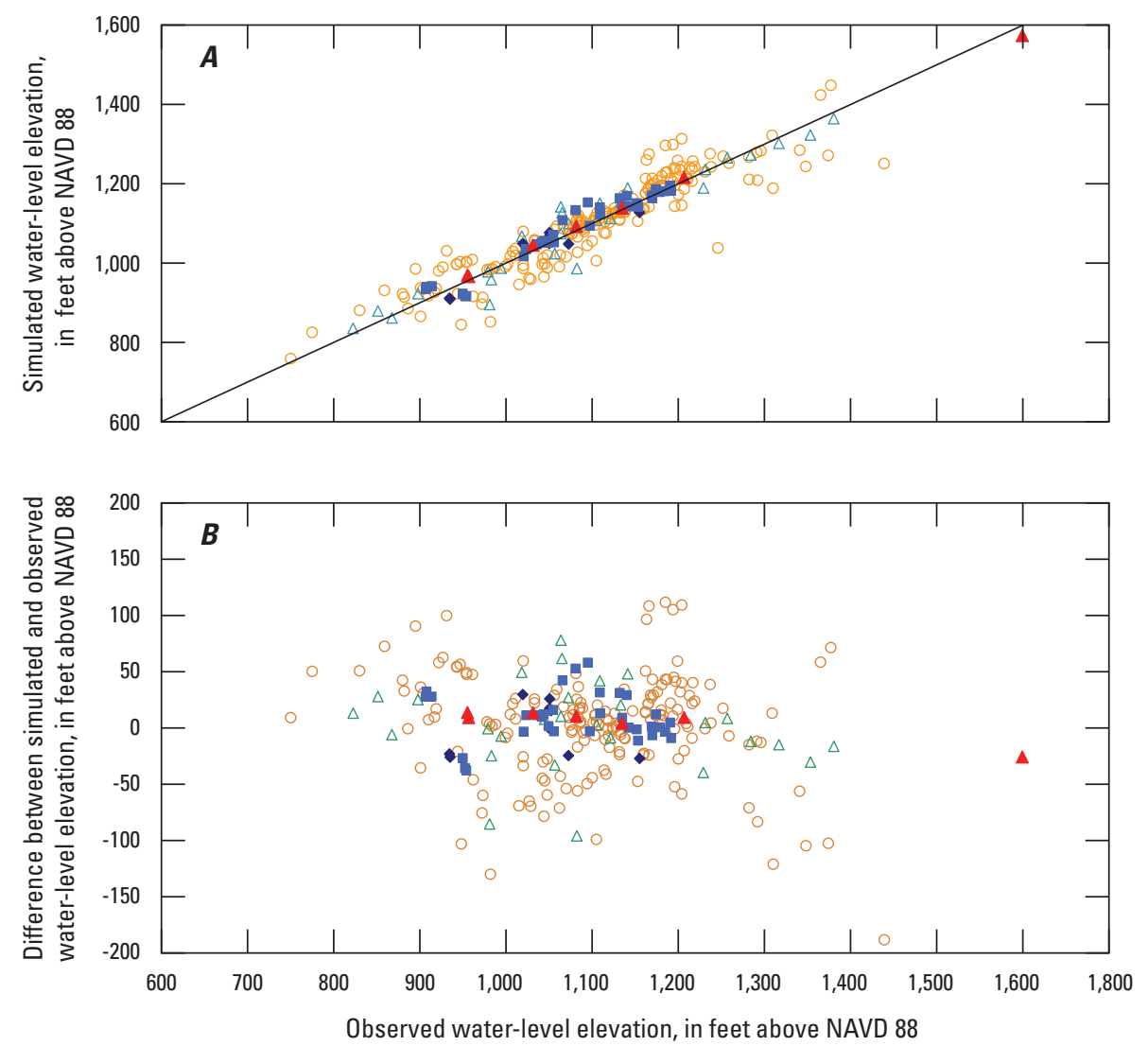

EXPLANATION Source of water-level data

- Susquehanna River Basin Commision

$\triangle \quad$ U.S. Geological Survey

- State College Borough Water Authority

- North American Water Systems

- Spring Creek Watershed Community

Figure 22. Observed steady-state groundwater levels in relation to $A$, MODFLOW-NWT simulated elevations and $B$, the difference between simulated and observed elevations for 257 wells in Spring Creek and Nittany Creek Basins and parts of the Spruce Creek Basin, Centre and Huntingdon Counties, Pennsylvania.) 


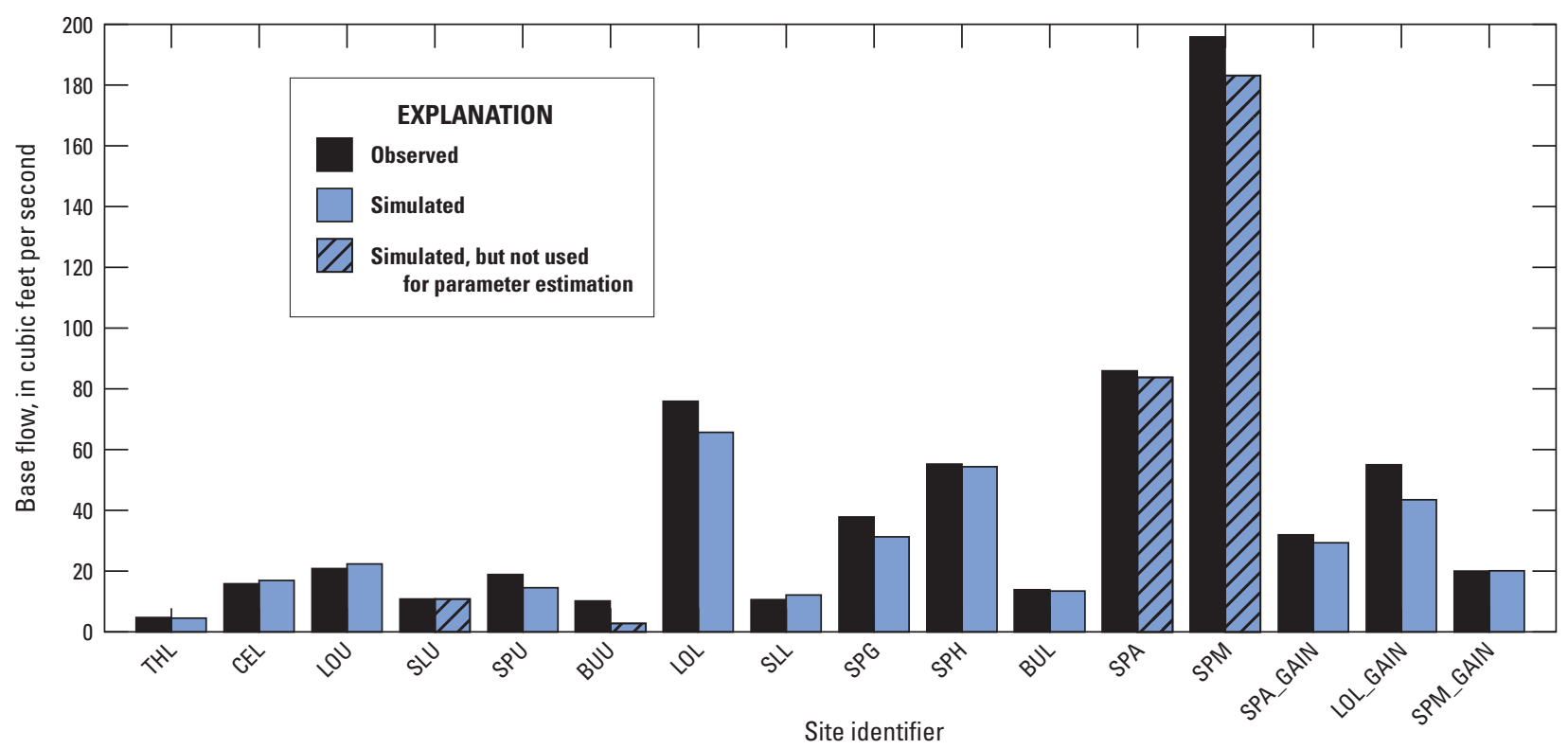

Figure 23. Observed steady-state base flows and steady-state base flows simulated by the MODFLOW-NWT model at 16 sites in Spring Creek and Nittany Creek Basins and parts of the Spruce Creek Basin, Centre and Huntingdon Counties, Pennsylvania, water years 2000-06. See tables 8 and 9 for description of site identifiers.

\section{Calibration of the Hydrologic Model and Simulation Results}

Surface-water and groundwater budgets were calculated for daily time steps in GSFLOW. Results from the GSFLOW model are reported for water years $2000-06$, but the simulation period included the 3-years prior to water year 2000, which provided time for the simulated hydraulic system to adjust from the initial conditions that were assigned to the model.

Calibration of the GSFLOW model was conducted in three steps. First, the parameters of the PRMS rainfall-runoff model and MODFLOW-NWT groundwater models were adjusted separately as stand-alone simulations that were not linked. Next, the simulated infiltration rates from PRMS were added to the MODFLOW-NWT model, and the MODFLOWNWT input parameters were readjusted using professional judgement and UCODE. Finally, after these preliminary adjustments, the separate models were linked in the GSFLOW code, and the parameters of both models were adjusted together for a final calibration by using the parameter estimation software PEST (Doherty, 2010, see http://pesthomepage. org for description of PEST). Hydrologic processes were computed in a fixed computation sequence that included four procedures as described in Markstrom and others (2008).

\section{Parameter Estimation with PEST}

In addition to issues of parameter insensitivity and correlation of observation data for constraining a coupled model, there are also concerns with measurement noise and redundant information in the large number of transient observations used to calibrate the fully coupled model. This is a primary concern here because areal surface-water data sets typically include many observations, especially with respect to the temporal density of the observations in a spatially distributed network; many of these data carry redundant insight into the system, but each contributes to the measurement noise that is encountered during calibration. In order to enhance the signal-to-noise ratio within the observation data, a time-series processing approach to the time-series observations was employed whereby the raw observations were processed and distilled into characteristic aspects of the system (Westenbroek and others, 2012). The simulated GSFLOW output was then processed in the same way as the raw observations and compared directly in the parameter estimation process. The processing was performed by using the Time-Series Processor TSPROC (Doherty, 2008; 
Westenbroek and others, 2012). TSPROC has the ability to read and process native PRMS and MODFLOW-NWT output files.

\section{Calibration Approach}

Whereas the sequentially linked calibration used representative steady-state water levels for groundwater model calibration, the fully coupled model is transient on a daily time step. Therefore, the time-series groundwater-levels measured during the study were included in the coupled model. In addition to the daily or intermittent values, the annual mean groundwater-levels were used for calibration.

In addition to the groundwater-level data, the following streamflow calibration targets were processed:

1. Log of daily streamflow - the natural log of daily streamflow was used to mitigate the undue influence of extremely high daily discharges on the calibration,

2. Annual mean streamflow - the average streamflow for each water year during the simulation period and represents the streamflow portion of the annual hydrologic budget,

3. Monthly mean streamflow - the average streamflow for each month during the simulation and represents the total monthly volume of streamflow,

4. Mean monthly streamflow - the streamflow for each month averaged over the entire simulation period and represents the seasonal variation of streamflow, and

5. Monthly mean base flow - the average base flow for each month during the simulation and represents the groundwater contribution to streamflow.

Because forward run times for the fully coupled model were multiple hours long, all parameters varied during the separate PRMS and MODFLOW-NWT calibrations could not be evaluated in the fully coupled model calibration. Thus, it is possible that undesirable artifacts from the uncoupled model calibration may not be completely addressed in the coupled model calibration. After some initial calibration tests, the final fully coupled model was calibrated by using the selected set of parameters listed in table 11. Some parameters not available in the steady-state MODFLOW-NWT-only calibration (for example, aquifer storage), parameters important for simulating the interface between the MODFLOW-NWT only and PRMSonly models, and parameters having utility for calibration of the coupled model (for example, vertical hydraulic conductivity of the unsaturated zone) were included. All but three of the parameters were used for final calibration control routing of infiltrated water through the subsurface; those three parameters affect precipitation storage in the form of snow. The fully coupled model calibration used singular value decomposition on the entire base parameter set. Of these parameters, the information content of the multi-objective function observation data supported approximately linear combinations of the base parameters (singular values) by using stability criteria $\left(\mathrm{PEST}\right.$ variable EIGTHRESH= $5.0 \times 10^{7}$ ) proposed by Doherty and Hunt (2010).

\section{Observation Weights}

In general, an estimate of uncertainty in the streamflow observations was used as a starting point for the weights for each observation group. The weight $\left(w_{g}\right)$ was assigned to be the reciprocal of the uncertainty for each group $\left(\sigma_{\mathrm{g}}\right)$; thus,

$$
w_{g}=\frac{1}{\sigma_{g}} .
$$

The uncertainties were estimated by using the coefficient of variation (standard deviation divided by the mean) and an average value for each observation group. Thus, the weight is estimated as

$$
w_{g}=\frac{1}{\mu_{g} C V_{g}},
$$

where $\mu_{g}$ and $C V_{g}$ are the mean and coefficient of variation of the observations for the group, respectively. For a log-transformed normally distributed variable, the standard deviation in log space was determined by rearranging the equations relating log-space $(y)$ moments to real-space $(x)$ moments (Miller and Freund, 1977):

$$
\sigma_{y}=\sqrt{\log \left(1+C V_{x}^{2}\right)}
$$

Because the groups contained observations at different time scales, there was a considerable difference in the number of observations within each group and from station to station. To compensate for the number of observations, the weights were adjusted to represent an equivalent number of annual, monthly, and mean monthly observations. This reasoning follows from the basic identity that the standard deviation of the mean $(m)$ from a random sample of size $n$ is given by

$$
\sigma_{m}=\frac{\sigma_{g}}{\sqrt{n}} .
$$

Because the weights are equal to the inverse of the standard deviation, the weight for a mean statistic becomes

$$
w_{m}=\frac{1}{\sigma_{m}}=\frac{\sqrt{n}}{\sigma_{g}}=w_{g} \sqrt{n} .
$$

The UCODE weights for the steady-state MODFLOWNWT calibration were used as a starting point for the weights for the fully coupled calibration. On the basis of experimentation, it was determined that the initial weights for the waterlevel data needed to be adjusted to assure that the water-level data were seen in the resulting objective function. The final non-zero weights used for the water-level data are given in table 12. The water-level data for well CE118 (fig. 13) was set to 0.0 in the final calibration, which removes the observation 


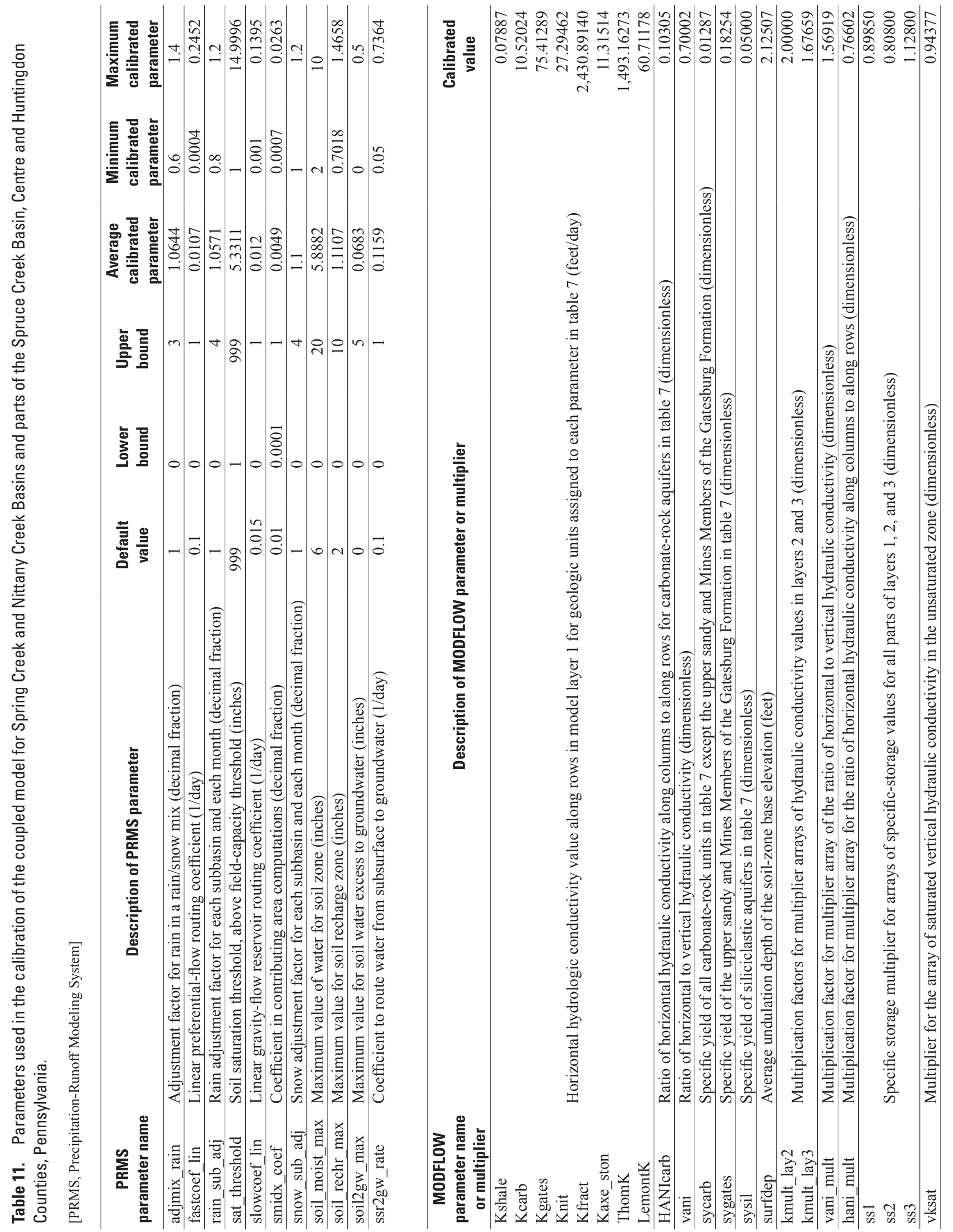


from consideration for the evaluation of model fit because it was causing instability in estimation of parameters; therefore, well CE118 is not listed in table 12. The final non-zero weights for the streamflow data are given in table 13. The streamflow data for upper Buffalo Run (BUL) and Thompson Run (THL) were zeroed out in the final calibration and, thus, are not shown in table 13 .

\section{Comparison of Simulated Results with Observations}

Simulated values of streamflow and groundwater levels from GSFLOW are compared to observations from 11 streamgages and 16 wells for water years 2000-06 in figures A1-A14 (see appendix). Model results are compared to calibration targets of the natural log of daily mean streamflow (fig. A1); annual streamflow, monthly mean streamflow, monthly mean base flow, and mean monthly streamflow (figs. A2-A12); and groundwater levels and annual mean groundwater-levels in observation wells (figs. A13-A14).

Simulated and observed results are compared graphically and with the Nash-Sutcliffe coefficient. The Nash-Sutcliffe coefficient is a widely used statistic to describe the accuracy of model simulations (Nash and Sutcliffe, 1970). The coefficient can vary between 1 and negative infinity, with 1 representing a perfect correspondence between simulated and observed values and values less than zero indicating that the mean value of the observations is a better predictor than the model results. Although the Nash-Sutcliffe coefficient has biases that affect the magnitude of the statistic, Moriasi and others (2007) consider a coefficient of greater than 0.5 to be one indicator of acceptable model performance.

\section{Streamflow and Base Flow}

Comparison of model simulations to observed values for the calibration targets indicates the calibrated GSFLOW model represents an acceptable simulation of streamflow and base flow for most sites, as shown graphically (figs. A1-A12) and by Nash-Sutcliffe coefficients that were generally greater than 0.5 . The exception was for the site Buffalo Run Lower where Nash-Sutcliffe coefficients were less than 0.5 for most of the calibration targets. The Nash-Sutcliffe coefficients for the streamflow and base-flow calibration targets are summarized in table 14.

Simulations of daily streamflow are considered acceptable for most sites (fig. A1). The model fit to daily streamflow was best (Nash-Sutcliffe coefficients of 0.70 and 0.73 ) for Spring Creek at Milesburg and for Spruce Creek at Graysville, respectively. Those two streamgages measured the major outflows from the study basin. Overall, simulation of streamflow appeared to be poorest for Buffalo Run Lower as indicated by Nash-Sutcliffe coefficients of less than 0.5 for most of the calibration targets. Simulation of low streamflows at Buffalo Run Lower seemed most problematic, which was also was the case at Logan Run Upper, and at the two streamgages on Slab Cabin Run. These streams have substantial losing reaches during low-flow periods, which probably are not being adequately simulated.

The simulations of annual mean streamflow (graph A in figs. A2-A12) are considered acceptable (Nash-Sutcliffe coefficients 0.65 to 0.96), except at the gaging station Buffalo Run Lower (Nash-Sutcliffe coefficient 0.41). During wet years of high streamflow, the model slightly overestimated annual streamflow at most sites, and during dry years streamflow generally was slightly underestimated. However, at streamgages Spring Creek Upper and Spruce Creek at Graysville, simulations underestimated annual streamflow for all years except for water year 2006, the last year of the simulation. The underestimates of streamflow at these sites are probably caused by simulating too much groundwater underflow from these subbains.

Table 12. Final weights used for groundwater-level data in the PEST transient calibration of the coupled model for Spring Creek and Nittany Creek Basins and parts of the Spruce Creek Basin, Centre and Huntingdon Counties, Pennsylvania.

\begin{tabular}{lc}
\hline \multicolumn{1}{c}{ Well name } & Weight $^{1}$ \\
\hline \multicolumn{1}{c}{ Continuous groundwater levels } \\
\hline BIG HOLLOW & 2.60 \\
CE686 & 1.25 \\
CENTRE HALL & 2.60 \\
FILMORE1 & 2.60 \\
NITTANY & 2.60 \\
PINEGROVE 2 & 1.25 \\
\multicolumn{1}{c}{ Intermittent groundwater levels } \\
CE 446 & 1.25 \\
CE 690 & 1.25 \\
CE 691 & 1.25 \\
CE 692 & 1.25 \\
CE 693 & 1.25 \\
CE 694 & 1.25 \\
CE 695 & 1.25 \\
CE 696 & 1.25 \\
CE 697 & 2.60 \\
CE 698 & 1.25 \\
Annual mean groundwater levels & \\
\hline CE 646 & 1.25 \\
CE 691 & 1.25 \\
CE 692 & \\
CE 693 & \\
CE 694 & \\
\hline
\end{tabular}

${ }^{1}$ Higher weight equals higher importance in the parameter estimation. 
Table 13. Final weights used for the streamflow data in the PEST transient calibration of the coupled model for Spring Creek and Nittany Creek Basins and parts of the Spruce Creek Basin, Centre and Huntingdon Counties, Pennsylvania.

\begin{tabular}{|c|c|}
\hline Stream name & Weight \\
\hline \multicolumn{2}{|c|}{ Log of daily streamflow } \\
\hline Buffalo Run lower & 2.53811 \\
\hline Cedar Run lower & 2.53811 \\
\hline Logan Run lower & 2.53811 \\
\hline Logan Run upper & 2.53811 \\
\hline Slab Cabin Run lower & 2.53811 \\
\hline Slab Cabin Run upper & 2.53811 \\
\hline Spring Creek at Houserville & 6.07350 \\
\hline Spring Creek at Milesburg & 6.07350 \\
\hline Spring Creek near Axemann & 6.07350 \\
\hline Spring Creek upper & 2.53811 \\
\hline Spruce Creek at Graysville & 1.90883 \\
\hline \multicolumn{2}{|c|}{ Annual average streamflow } \\
\hline Buffalo Run lower & 22.75233 \\
\hline Cedar Run lower & 19.90946 \\
\hline Logan Run lower & 4.19137 \\
\hline Logan Run upper & 15.16822 \\
\hline Slab Cabin Run lower & 29.69118 \\
\hline Slab Cabin Run upper & 0.00093 \\
\hline Spring Creek at Houserville & 13.84030 \\
\hline Spring Creek at Milesburg & 0.00012 \\
\hline Spring Creek near Axemann & 0.00028 \\
\hline Spring Creek upper & 16.76733 \\
\hline Spruce Creek at Graysville & 6.28705 \\
\hline \multicolumn{2}{|c|}{ Monthly average streamflow } \\
\hline Buffalo Run lower & 6.56803 \\
\hline Cedar Run lower & 5.74736 \\
\hline Logan Run lower & 1.20994 \\
\hline Logan Run upper & 4.37869 \\
\hline Slab Cabin Run lower & 8.57111 \\
\hline Slab Cabin Run upper & 0.00027 \\
\hline Spring Creek at Houserville & 3.99535 \\
\hline Spring Creek at Milesburg & 0.00004 \\
\hline Spring Creek near Axemann & 0.00008 \\
\hline Spring Creek upper & 4.84031 \\
\hline Spruce Creek at Graysville & 1.81491 \\
\hline
\end{tabular}

\begin{tabular}{lc}
\hline \multicolumn{1}{c}{ Stream name } & Weight \\
\hline \multicolumn{1}{c}{ Monthly average base flow } \\
\hline Buffalo Run lower & 6.56803 \\
Cedar Run lower & 5.74736 \\
Logan Run lower & 1.20994 \\
Logan Run upper & 4.37869 \\
Slab Cabin Run lower & 8.57111 \\
Slab Cabin Run upper & 0.00027 \\
Spring Creek at Houserville & 3.99535 \\
Spring Creek at Milesburg & 0.00004 \\
Spring Creek near Axemann & 0.00008 \\
Spring Creek upper & 4.84031 \\
Spruce Creek at Graysville & 1.81491 \\
\hline \multicolumn{1}{c}{ Mean monthly streamflow } \\
\hline Buffalo Run lower & 17.37738 \\
Cedar Run lower & 15.20610 \\
Logan Run lower & 3.20121 \\
Logan Run upper & 11.58492 \\
Slab Cabin Run lower & 22.67701 \\
Slab Cabin Run upper & 0.00071 \\
Spring Creek at Houserville & 10.57070 \\
Spring Creek at Milesburg & 0.00009 \\
Spring Creek near Axemann & 0.00021 \\
Spring Creek upper & 12.80626 \\
Spruce Creek at Graysville & 4.80181 \\
\hline & \\
\hline & \\
\hline & \\
\hline & \\
\hline & \\
\hline & \\
\hline
\end{tabular}


The simulations of monthly mean streamflow (graph B in figs. A2-A12) are acceptable (Nash-Sutcliffe coefficients 0.75 to 0.92 ), except at Buffalo Run Lower. The timing and magnitude of the simulated monthly mean streamflow corresponds reasonably well to the observed streamflow. During dry periods of low flow, the fit of simulated to observed monthly mean streamflow was better than the fit to daily flow for the same periods.

Mean monthly streamflow is the mean of all monthly mean flows for a particular month for the 7-year simulation period. Simulated values of mean monthly streamflow are shown in graph D (figs. A2-A12), where observation numbers 1 through 12 correspond to months of the calendar year. Comparisons of simulated and observed mean monthly flow highlight the seasonal errors in flow that are difficult to notice in graphs of daily or monthly mean streamflow. At seven of the streamgages, simulations underestimated high flows in March and April. At four streamgages, the Nash-Sutcliffe coefficient for mean monthly streamflow was less than 0.5 (table 14); at those sites streamflow tended to be underestimated during most months.

Similar to the monthly means, simulations of monthly mean base flows (graph C in figs. A2-A12) are considered acceptable (Nash-Sutcliffe coefficients 0.54 to 0.87 ) except at the gaging station Buffalo Run Lower (Nash-Sutcliffe coefficient 0.38 ). The magnitude of simulated base-flow fluctuations is less than was observed at many of the streamgages during water years 2000-02, yet the timing of the highs and lows is correct (observations 1 through 36 on graph $\mathrm{C}$ in figs. A2-A12). For 2003-06, both the timing and magnitude of the simulated and observed streamflow is predictive and consistent with monthly mean streamflows.

\section{Groundwater Levels}

Transient groundwater levels, a lesser objective of calibration, were not well simulated as shown graphically and by Nash-Sutcliffe coefficients of less than zero at most of the 16 wells (figs. A13 and A14). The timing and magnitude of simulated groundwater-level fluctuations can only be considered acceptable for three wells used for calibration - CE 686, Centre Hall, and CE 692. At some wells, the magnitude of the simulated fluctuation was reasonable, but the starting elevation was too high or low (CE 691 and CE 697); at some wells the simulated elevation was reasonable, but the fluctuations were not adequately simulated (Nittany, CE 693, and CE 695); and at some wells, neither the simulated fluctuations nor elevation were acceptable (CE 698, Pine Grove 2).

The poor fit of the model to observed groundwater levels relative to the fit of the model to observed streamflows was not unexpected because the zone-based parameterization of the GSFLOW model is best suited for predictions that integrate large areas of the model domain (such as flux targets), whereas water-level targets are more local. Therefore, the structural error associated with the simplified zone-based model makes it difficult to accurately simulate of groundwater levels in the complex geologic setting of the study area.

Table 14. Nash-Sutcliffe coefficients of model efficiency for streamflow calibration targets in the Spring Creek and Nittany Creek Basins and parts of the Spruce Creek Basin, Centre and Huntingdon Counties, Pennsylvania, water years 2000-06.

$[--$, not available $]$

\begin{tabular}{lccccc}
\hline \multirow{2}{*}{ Streamgage site } & \multicolumn{5}{c}{ Calibration target and Nash-Sutcliff coefficient } \\
\cline { 2 - 6 } & $\begin{array}{c}\text { Natural log of } \\
\text { daily streamflow }\end{array}$ & $\begin{array}{c}\text { Annual mean } \\
\text { streamflow }\end{array}$ & $\begin{array}{c}\text { Monthly mean } \\
\text { streamflow }\end{array}$ & $\begin{array}{c}\text { Monthly mean } \\
\text { base flow }\end{array}$ & $\begin{array}{c}\text { Mean monthly } \\
\text { streamflow }\end{array}$ \\
\hline Spring Creek near Axemann, PA & 0.65 & 0.93 & 0.92 & 0.87 & 0.84 \\
Buffalo Run Lower & 0.47 & 0.41 & 0.48 & 0.28 & 0.38 \\
Cedar Run Lower & 0.61 & 0.65 & 0.75 & 0.75 & 0.55 \\
Spring Creek at Houserville, PA & 0.58 & 0.90 & 0.91 & 0.82 & 0.83 \\
Logan Branch Lower & 0.58 & -- & 0.78 & 0.74 & 0.54 \\
Logan Branch Upper & 0.52 & 0.71 & 0.75 & 0.64 & 0.73 \\
Spring Creek at Milesburg & 0.70 & 0.91 & 0.90 & 0.86 & 0.79 \\
Spring Creek Upper & 0.53 & 0.72 & 0.75 & 0.54 & 0.23 \\
Spruce Creek at Graysville, PA & 0.73 & 0.89 & 0.82 & 0.85 & -0.16 \\
Slab Cabin Run Lower & 0.55 & 0.81 & 0.83 & 0.80 & 0.71 \\
Slab Cabin Run Upper & 0.50 & 0.96 & 0.84 & 0.74 & 0.35 \\
\hline
\end{tabular}




\section{Water Budget and Groundwater Recharge}

The principal objectives of this project were to simulate the water budget and estimate the distribution of groundwater recharge for the study basin for water years 2000-06 by the use of GSFLOW. GSFLOW provides two output files that can be used to view water budgets for the major components of the hydrologic cycle. An example of the annual water budgets compiled from the main GSFLOW output file (gsflow_FINALBUDGET.out) is presented in table 15. Values of other water-budget terms are provided in the GSFLOW CommaSeparated Values (CSV) output file (gsflow.csv). These output files are available from the GSFLOW model archive, available upon request from the USGS Pennsylvania Water Science Center.

\section{Basin Water Budget}

Water budgets simulated by GSFLOW for water years 2000-06 are summarized in table 15 as volumes of inflow, outflow, and storage change for each water year and for the entire period. The largest source and sink terms are represented by precipitation and evapotranspiration, respectively. For water years 2000-06, precipitation was more than 99 percent of all inflow; evapotranspiration and streamflow together accounted for 98 percent of all outflow. Withdrawals by wells and quarries represented about 2 percent of the outflow. For water years 2000-06, total inflows of water exceeded total outflows by about 1.7 billion cubic feet $(0.47$ inches per year over the basin area), so the simulated total storage of water in the basin increased by an amount about equal to the surplus inflow. Contributions from precipitation, streamflow gains, inter-basin groundwater exchanges such as those from the northeast and southwest portions of the study basin, and well withdrawals/injection exceeded those outflows from evapotranspiration, streamflow losses, inter-basin losses, and well withdrawals/injection.

The major terms of the water budget simulated by GSFLOW are shown for water years 2000-06 in figure 24. Water year 2001 was the driest year during the study period and 2004 was the wettest year in terms of both simulated annual precipitation and streamflow (table 15 and fig. 24). Annual outflow as evaporation was relatively constant, however, averaging about 14 billion cubic feet per year, indicating that water is generally available to satisfy the environmental demand for evapotranspiration as simulated by the model. The volume of water in storage increased most in water year 2003, which was a wet year preceded by a dry year, and decreased most during water year 2005, which was a dry year preceded by a wet year.

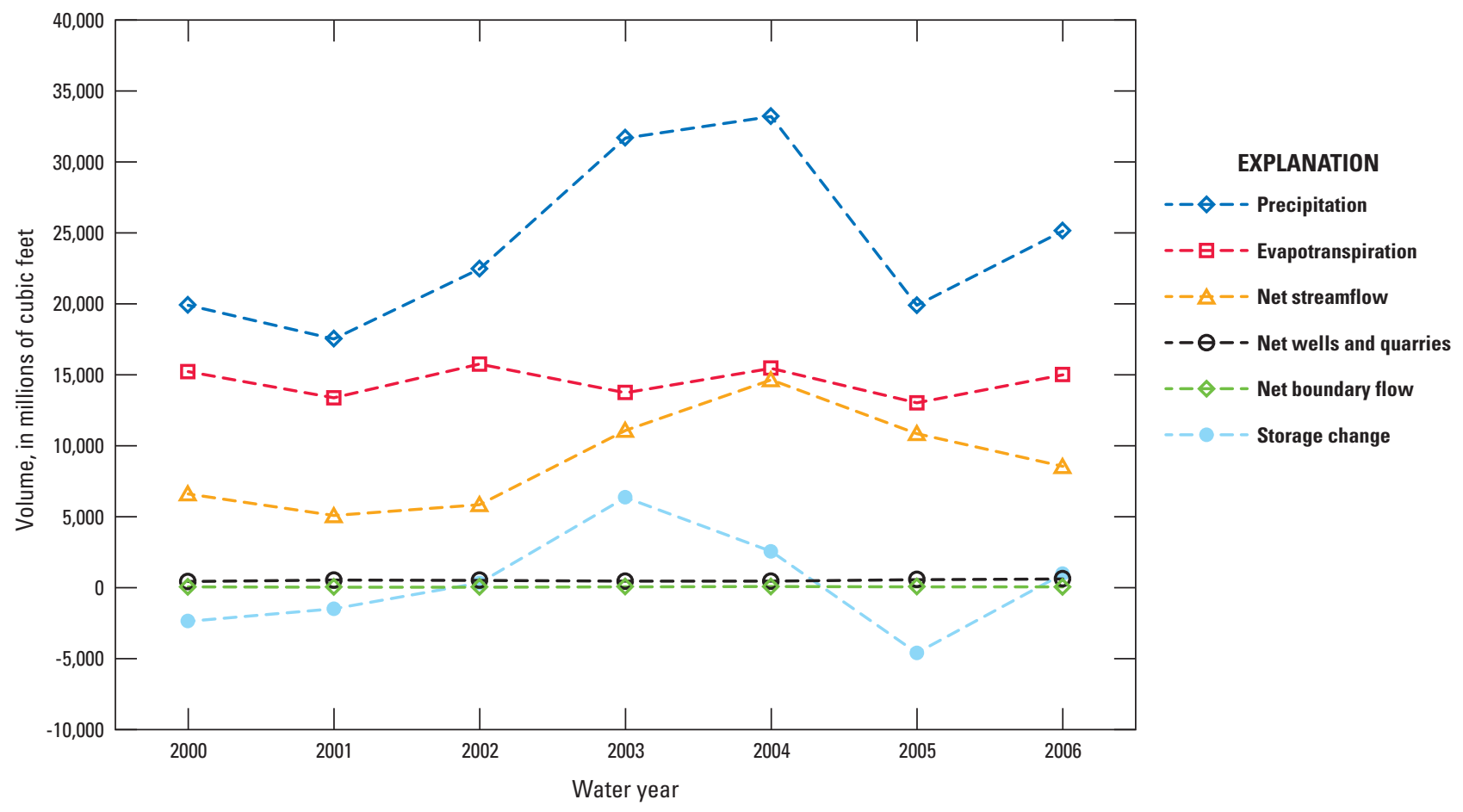

Figure 24. Summary of annual water-budget terms from the GSFLOW simulation, Spring Creek and Nittany Creek Basins and parts of the Spruce Creek Basin, Centre and Huntingdon Counties, water years 2000-06. 
44 Water-Budget and Recharge-Area Simulations, Centre and Huntingdon Counties, Pennsylvania, Water Years 2000-06

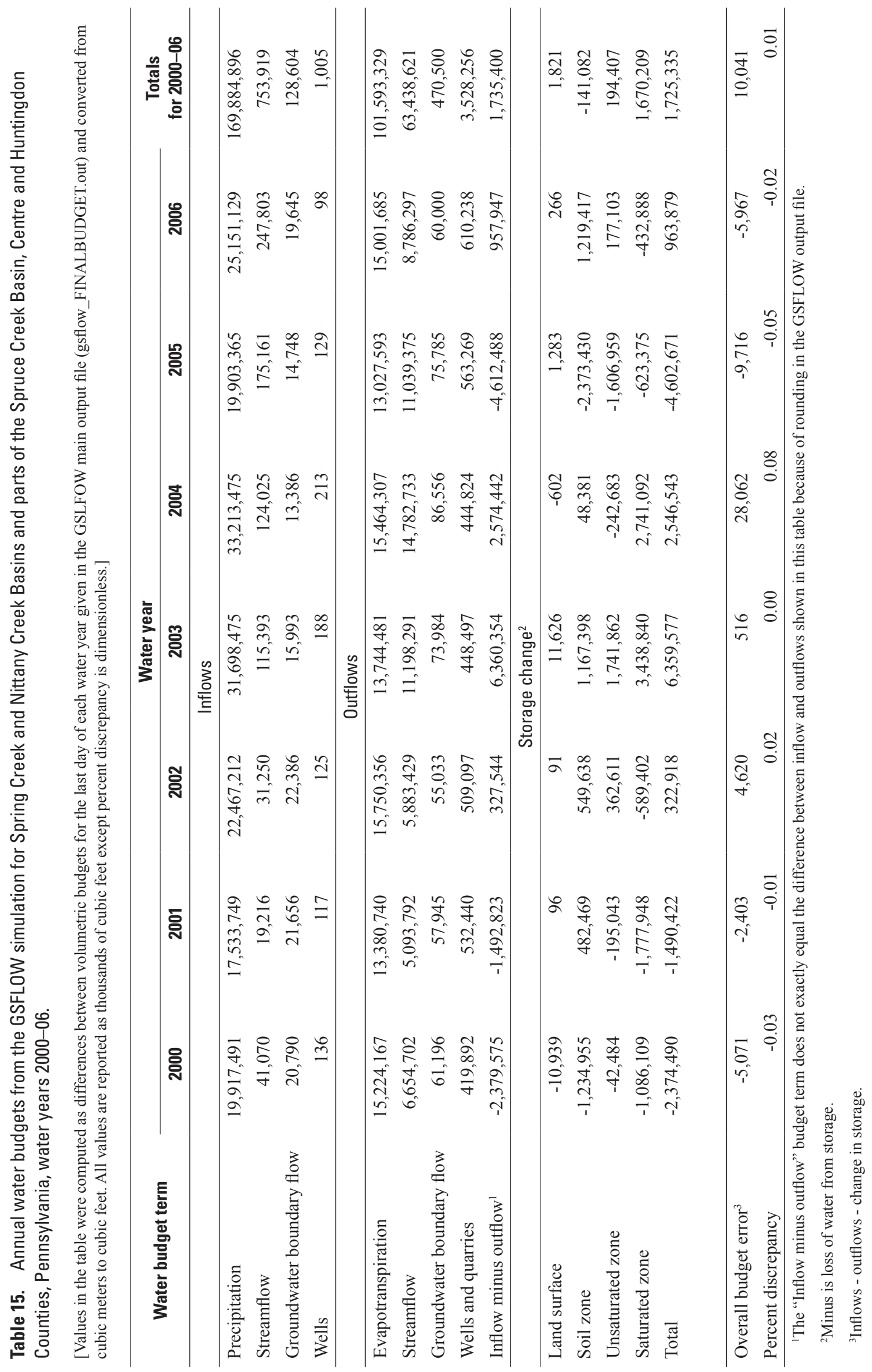


Simulated daily fluxes for the major budget terms (precipitation, evapotranspiration, and streamflow) from the GSFLOW Comma Separated Value (CSV) output file are shown in figure 25 . The regular seasonal variability of evapotranspiration is apparent - high rates of water loss in the summer and low rates of loss in the winter. Simulated streamflow was low many days during water years 2000 and 2001, as well as during the summer months of water years 2005 and 2006.

An estimate of annual groundwater recharge from GSFLOW was summarized in table 16 from simulated values of daily flux of water from the unsaturated zone to the saturated zone (uzf recharge). Recharge from the unsaturated zone, expressed as a depth over the study area, ranged from
5.4 inches in 2001 (the driest year) to 22 inches in 2004 (the wettest year) and averaged about 12.4 inches. The GSFLOW model average for water years 2000-06 is less than the estimate of 15.2 inches of groundwater recharge derived from base-flow separation of the streamflow hydrograph. Recharge, expressed as a percentage of precipitation, ranged from 16 percent in water years 2001 and 2002 to 42 percent in water year 2005. The large amount of recharge relative to precipitation in water year 2005 was caused by infiltration of precipitation during previous wet years that did not reach the saturated zone until water year 2005.

Variability in the simulated daily flux of recharge from the unsaturated zone to the saturated zone (uzf_recharge) is

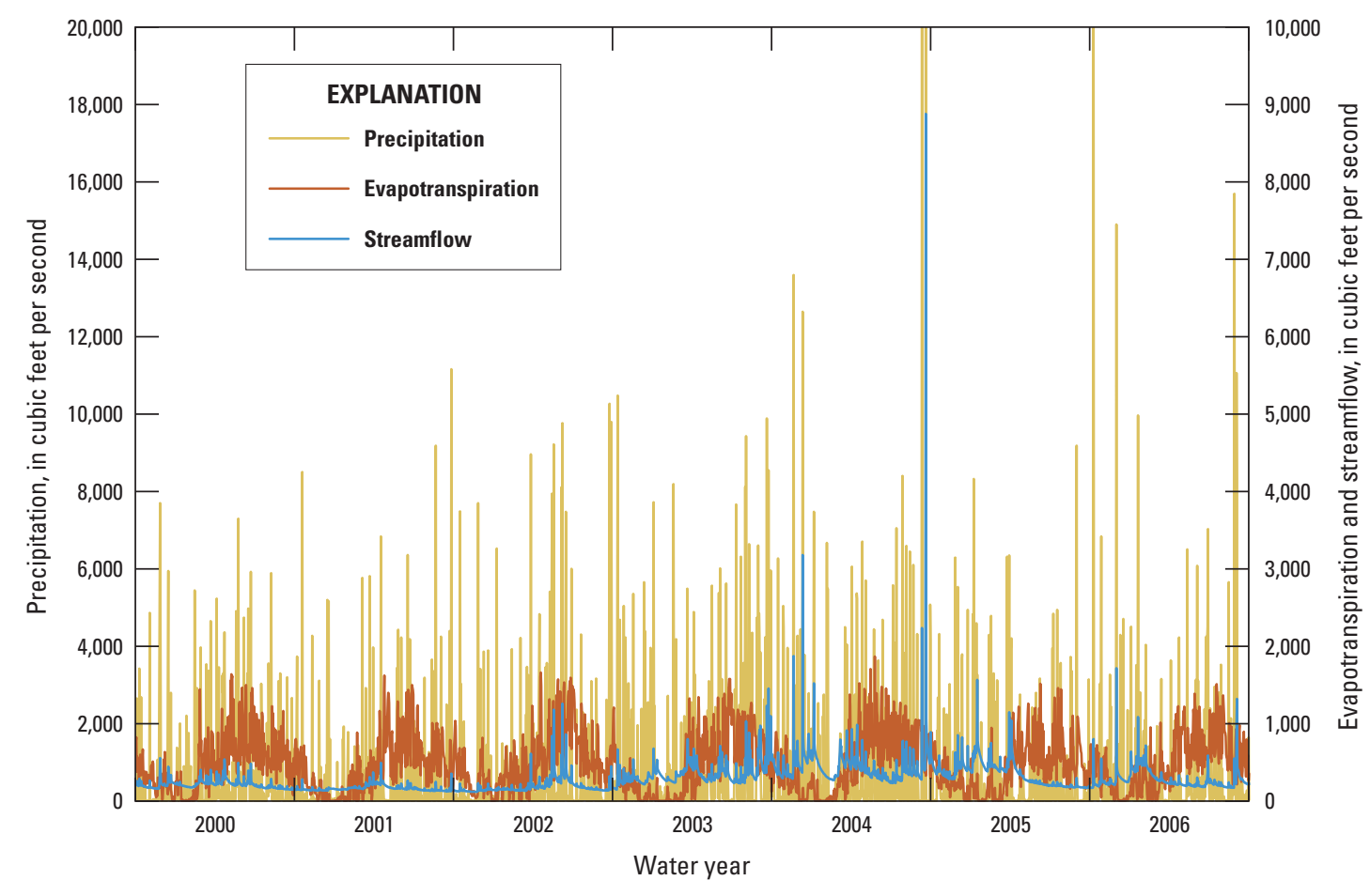

Figure 25. Daily fluxes of precipitation (basinppt), evapotranspiration (basinactet), and streamflow (basinstrmflow) from the GSFLOW Comma Separated Value (CSV) output file.

Table 16. Simulated flux of recharge from the unsaturated zone to the saturated zone (uzf_recharge) derived from the GSFLOW Comma Separated Value (CSV) output file.

\begin{tabular}{|c|c|c|c|c|c|c|c|}
\hline \multirow{2}{*}{$\begin{array}{l}\text { Mean recharge rate from } \\
\text { unsaturated to saturated zone } \\
\text { (uzf_recharge) }\end{array}$} & \multicolumn{7}{|c|}{ Water year } \\
\hline & 2000 & 2001 & 2002 & 2003 & 2004 & 2005 & 2006 \\
\hline In cubic feet per second & 132 & 91 & 112 & 308 & 370 & 265 & 182 \\
\hline As inches per year & 7.8 & 5.4 & 6.6 & 18.3 & 22.0 & 15.8 & 10.8 \\
\hline As percent of precipitation & 21 & 16 & 16 & 31 & 35 & 42 & 23 \\
\hline
\end{tabular}


Water-Budget and Recharge-Area Simulations, Centre and Huntingdon Counties, Pennsylvania, Water Years 2000-06

shown in figure 26. The amount of recharge varied seasonally in water years 2000, 2001, 2005 and 2006-recharge was greater in the winter and spring than in the summer and fall. However, in water years 2002-04 substantial amounts of water recharged the saturated zone regardless of season.

The recharge from the unsaturated zone to the saturated zone (uzf_recharge) is compared to basin streamflow in figure 27. Recharge was much less than the base streamflow for dry periods in water years 2000-02 and 2005-06; during those times the streamflow was being sustained by depletion of groundwater storage. This comparison illustrates why base flows determined by the use of hydrograph-separation methods are not usually a good approximation of groundwater recharge at time scales of less than one year.

\section{Groundwater Recharge}

The distribution of net recharge derived from GSFLOW across the basin is illustrated for the driest water year of the study period (2001) in figure 28 and the wettest water year (2004) in figure 29. Areas in the basin where rates of groundwater recharge are much higher than average, especially during wet years, might be considered critical for maintaining the flow of springs, stream base flow, or the source of water to supply wells.

Net recharge derived from GSFLOW differs from the infiltration flux from PRMS in that net recharge from GSFLOW is the net difference in the exchange of water between the saturated zone and land surface by MODFLOWNWT grid cell, whereas infiltration from PRMS is a downward vertical flux that originates at the land surface summarized by HUC. Thus, the resulting GSFLOW net recharge distributions for 2001 and 2004 in figures 28 and 29 differ from the PRMSonly infiltration (fig. 9) and are attributed to a more complete accounting of water in the GSFLOW model. The net recharge is useful for assessing the areal distribution of locations where recharge exceeds groundwater discharge. The sum of net recharge for all cells does not equal total recharge for the basin because of the large negative net recharge values computed for model cells having gaining streams and surface leakage. Net recharge rate for each cell is computed as

$\begin{aligned} \text { Net recharge }= & (\text { Recharge }- \text { Groundwater ET }- \text { Surface } \\ & \text { leakage }- \text { Stream seepage })\end{aligned}$

where

Recharge is water added to the saturated zone from the UZF package,

Groundwater ET is evapotranspiration from the saturated zone,
Surface leakage is groundwater discharge to the land surface where the water table intercepts the land surface, and

Stream seepage at model cells with streams, is groundwater discharge to stream or streamflow loss to groundwater.

The maps of the simulated distribution and magnitude of annual net recharge differ for water years 2001 (fig. 28) and 2004 (fig. 29). In the dry water year 2001, the net recharge for most model cells was 0 to 1,000 cubic feet per day (red and orange cells). Net recharge was greater than 1,500 cubic feet per day (green, blue, and purple cells) in a few model cells in valleys along losing streams. Net recharge was less than zero (white cells) in areas where water from the saturated zone was discharging to land surface on mountains and along gaining streams. In the wet water year 2004, except for the mountain areas, net recharge in model cells mostly ranged from 1,500 to 5,000 cubic feet per day (green and blue cells) and was even greater (purple cells) in a few valleys along losing streams (fig. 29).

The differences between the wet and dry water years are highlighted in figure 30, which shows the simulated net recharge for water year 2004 minus net recharge for water year 2001. The difference was positive in most parts of the basin, indicating that net recharge was greater in 2004 than in 2001. Areas with the greatest increase in recharge include model cells in the Scotia Barrens and valley floor between there and Bellefonte, along the toe slopes of Tussey and Bald Eagle Mountains, and some cells along Nittany Mountain. The Scotia Barrens, located west of State College, are approximately $200 \mathrm{ft}$ higher than the Nittany Valley floor. The ridge is underlain by the Gatesburg Formation, which is characterized by a coarse-grained dolomite, interbedded orthoquartzite and sandy dolomite (Fulton and others, 2005). The substantially greater net recharge in that area for 2004 compared to 2001 is a function of the thick unsaturated zone, large specific yield, and large hydraulic conductivity associated with the Gatesburg Formation.

The difference between net recharge in 2004 and 2001 was negative in a few areas on the mountains and along streams (orange and red cells). Simulated net recharge was greater during 2001 than during 2004 in a few parts of Tussey, Nittany, and Bald Eagle Mountains because the water table rose during the wet year 2004, causing discharge of water from the saturated zone to land surface to increase, which reduced net recharge. Net recharge was also less in 2004 than in 2001 in model cells along some streams because substantially greater amounts of water discharged along stream valleys during the wet year 2004 than during the dry year 2001. 


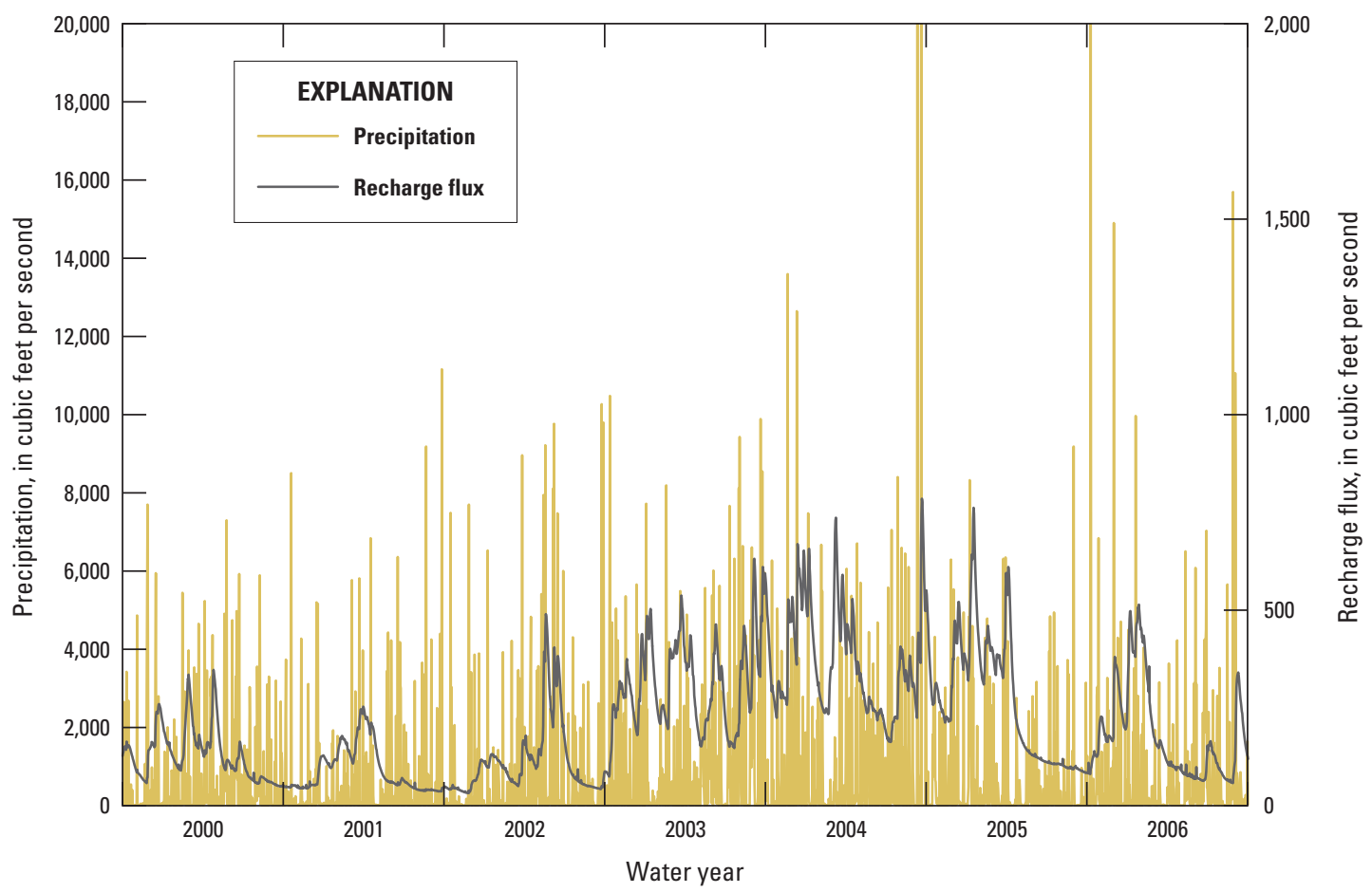

Figure 26. Daily fluxes of precipitation (basinppt) and recharge from the unsaturated zone to the saturated zone (uzf_recharge) from the GSFLOW Comma Separated Value (CSV) output file.

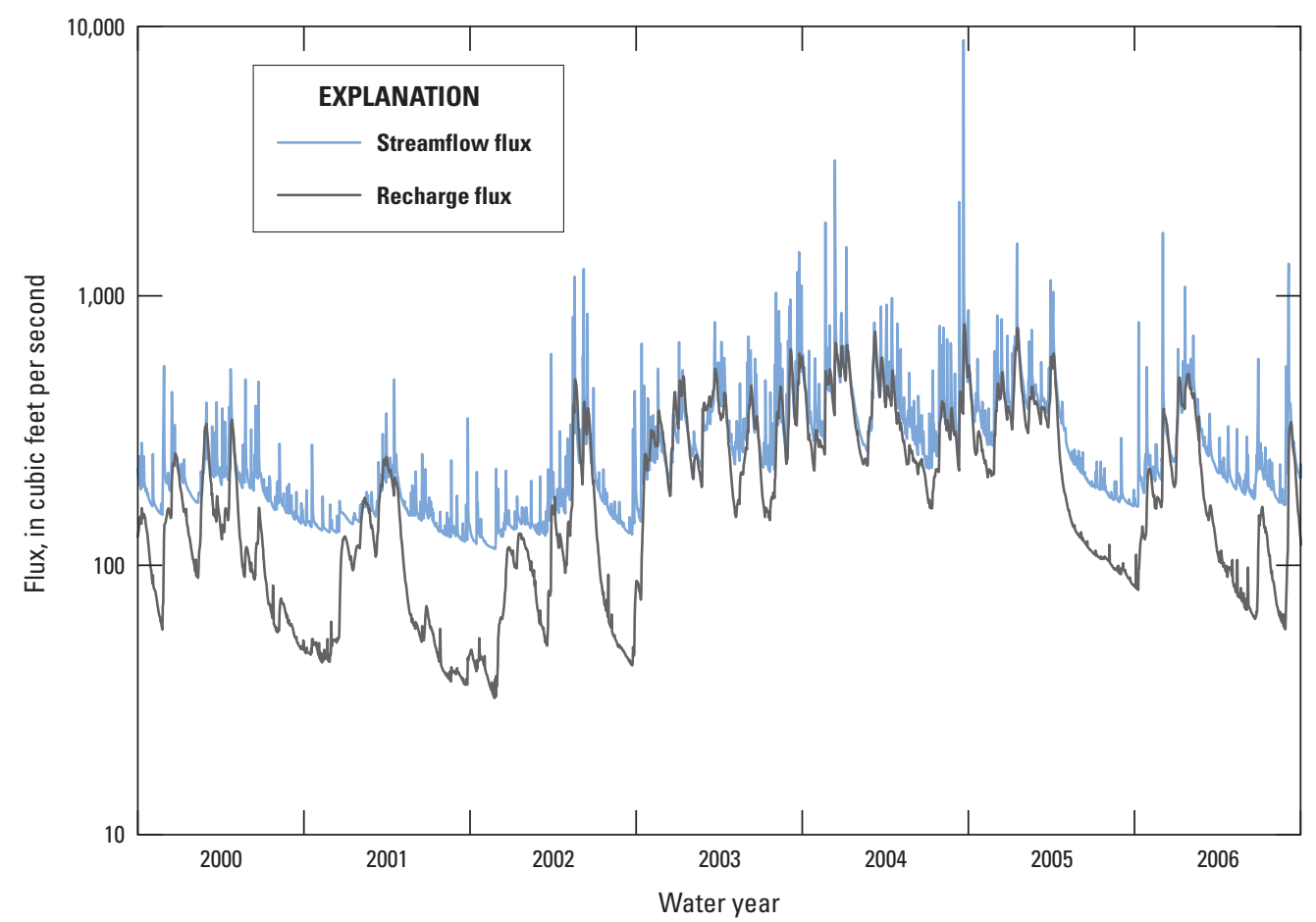

Figure 27. Daily fluxes of streamflow (basinstrmflow) and recharge from the unsaturated zone to the saturated zone (uzf_recharge) derived from the GSFLOW Comma Separated Value (CSV) output file. 


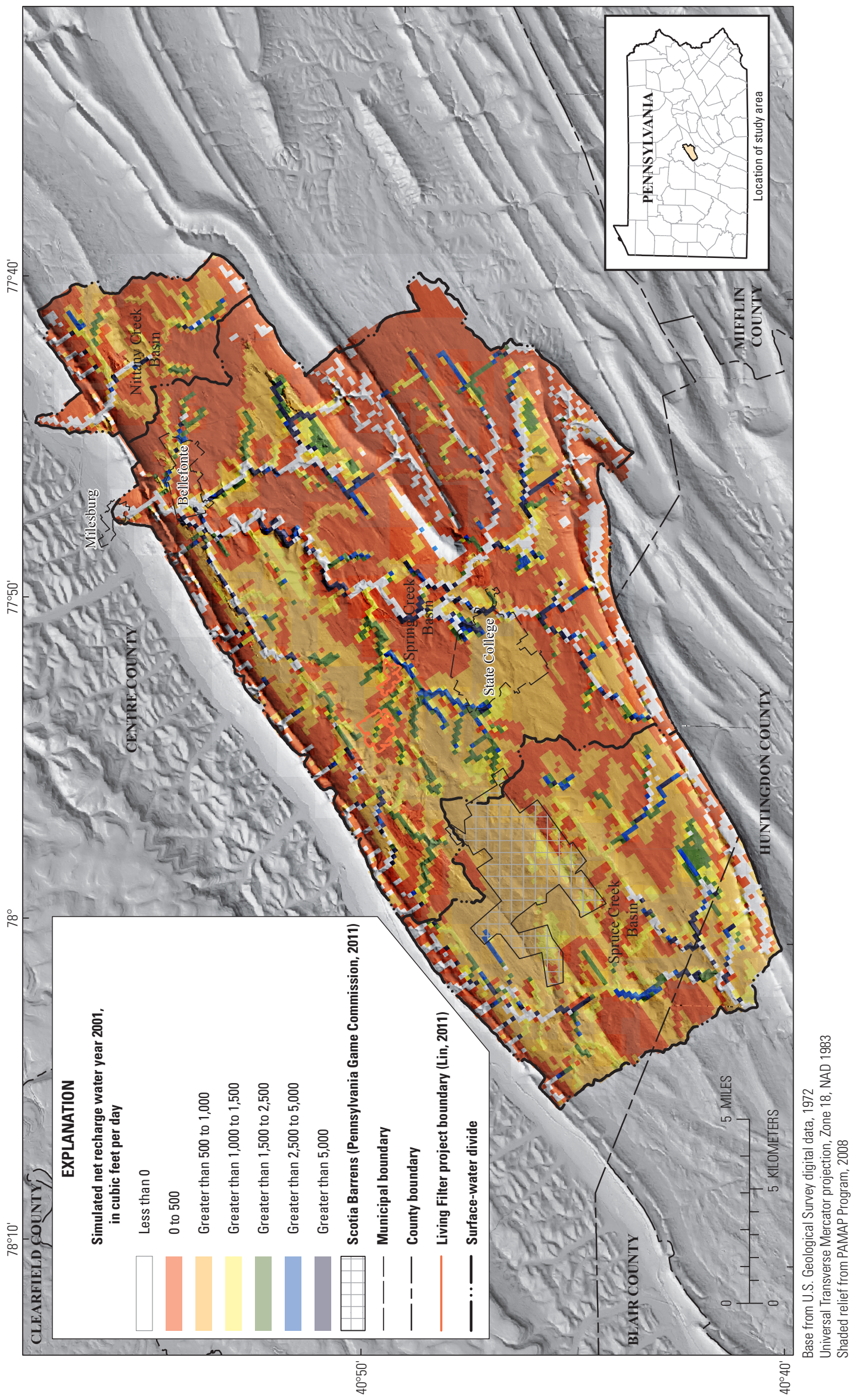

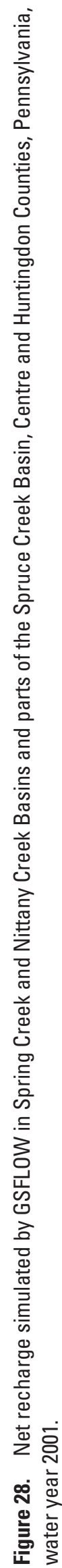



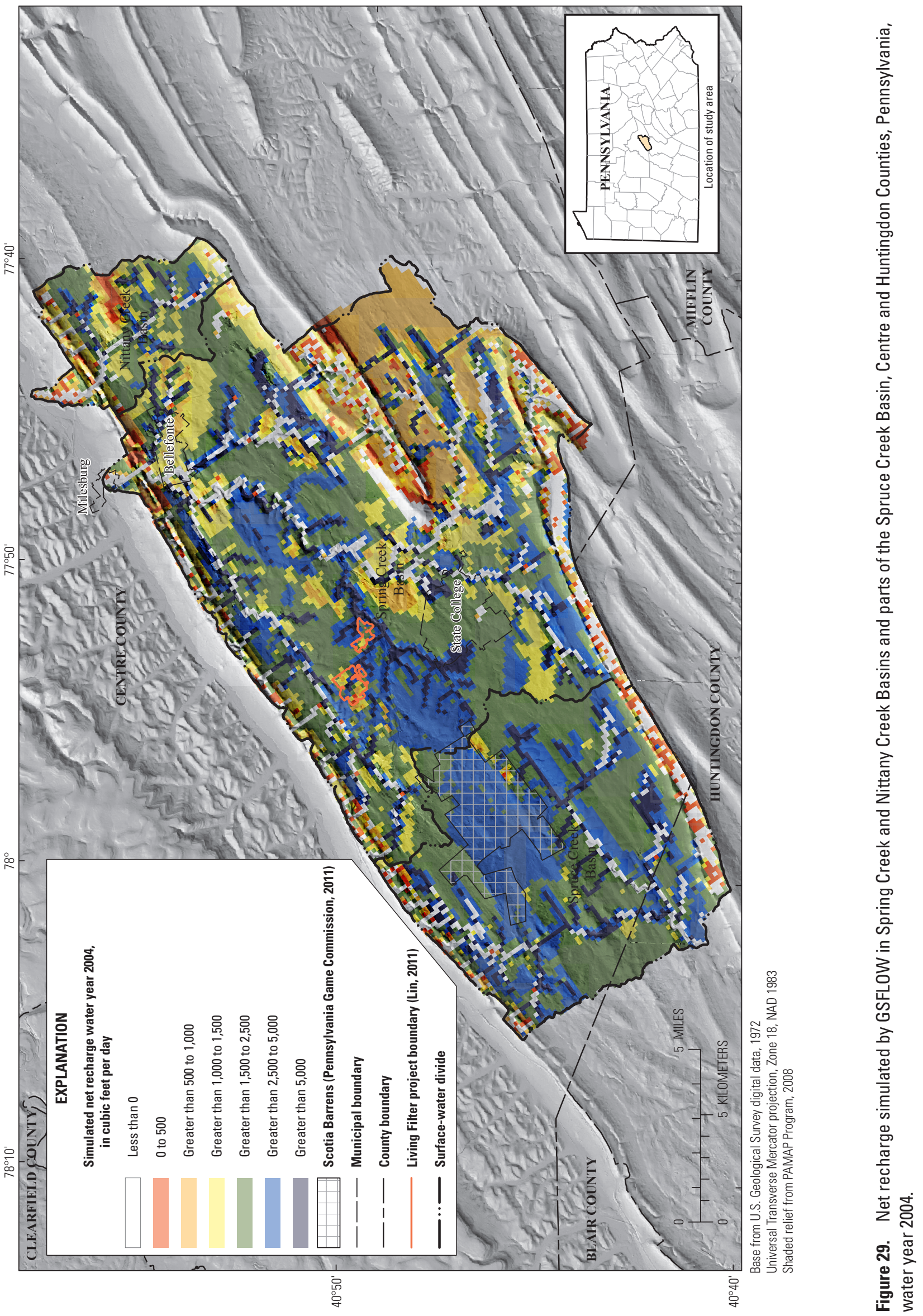


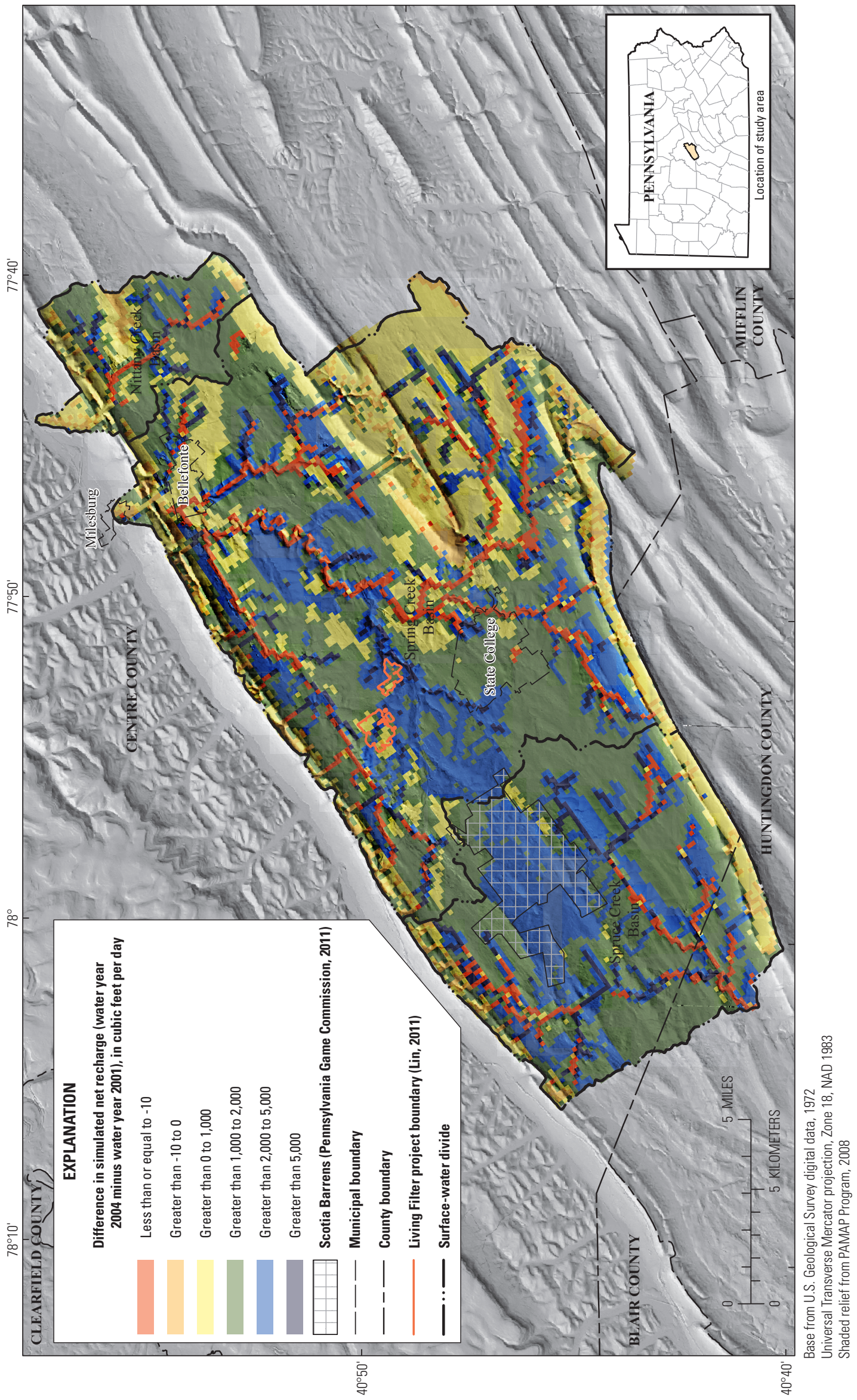

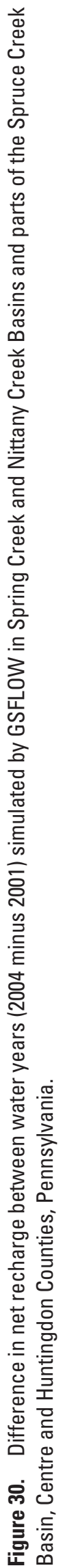




\section{Model Limitations}

The hydrologic model of the Spring Creek and Nittany Creek Basins, and parts of the Spruce Creek Basin was developed to simulate a basin-scale water budget and groundwater recharge for water years 2000-06. The model is probably adequate for simulating the regional water budget; however, substantial errors between simulated and observed groundwater levels suggest that use of the maps of groundwater recharge should be limited to providing general information about the overall pattern and magnitude of spatial variability in recharge.

The GSFLOW model developed for the basin is limited by the availability and reliability of data used for its construction and calibration, but the principal limitations are probably the result of model simplifications and spatial resolution. Development of a numerical model requires simplification of the regional groundwater/surface-water system; however, for this study basin in karst terrain, simplification of the extreme heterogeneity with respect to hydraulic conductivity may not allow accurate representation of groundwater levels and flows, especially at the local scale. Thus, simulated results from GSFLOW at the local scale may not compare closely to observed fluxes or levels. Comparisons of simulated and observed daily streamflows and groundwater levels show the degree to which the GSFLOW model was able to match local observations. Some locations are well characterized by the GSFLOW model; in other areas, the GSFLOW model is a poor representation of the natural system. Although the model provides a reasonable assessment of the basin water budget and streamflow hydrographs for the period 2000-06, caution should be used when examining model results at specific locations.

The spatial resolution that could be simulated in the GSFLOW model was limited by the horizontal and vertical model discretization. The topographically and hydrogeologically delineated HRUs, with stream buffers based on a width of 1,312 feet (400 meters), may have introduced surfacewater/groundwater interaction zones that are not based on the true riparian areas for each stream segment and do not include the full extent of the riparian areas of stream segments. In addition, the resolution of the MODFLOW-NWT cells, 656 by 656 feet ( 200 by 200 meters) in horizontal dimension, allowed only a coarse representation of the interaction between groundwater and streams because the groundwater head at the stream was averaged over the large area of the cell, and because the physical stream-segment properties may not have been accurately represented. The timing of streamflow routing between stream segments might have been improved by using a kinematic wave method in the SFR2 package.

However, because the model uses a daily time step, use of advanced streamflow routing methods was determined to be unnecessary. The thick vertical layers in the model of 300 feet were used to help mitigate computational difficulties caused by the steep relief on the mountains, affecting the ability to accurately simulate shallow groundwater levels, especially in areas where vertical gradients are greatest, such as beneath the mountains and streams.

The hydrologic model could be used to compare simulations of historic conditions of climate or land use during water years 2000-06 to simulations with alternative values for those conditions. Evaluation of differences between the simulations could be used to help understand the effects of those alternative conditions on the water budget and groundwater recharge. As a planning tool, the model could be used to simulate the effects of future hypothetical changes at the basin scale.

\section{Summary and Conclusions}

Rapid growth and development in the study basin (Spring Creek and Nittany Creek Basins and the headwaters of Spruce Creek Basin) has resulted in land-use changes and increased water use, influencing (1) the quantity and availability of runoff and groundwater, (2) surface-water/groundwater interactions, and (3) aquatic resources in the study basin. Because of the hydrologic connectivity between surface-water and groundwater in parts of the basins, a hydrologic model that accounts for groundwater and surface-water components (GSFLOW model) was constructed to simulate the interactions between both systems.

ClearWater Conservancy and the Pennsylvania Department of Environmental Protection identified a number of priorities for the project, two of which were to (1) create a coupled-regional model to compute the water budget for the study basin using GSFLOW for water years 2000-06 and (2) identify areas of greater than average recharge, which can be used by decision makers in managing water resources in the study basin.

The cumulative and annual water budgets for water years 2000-06 for each of the storage reservoirs were simulated by GSFLOW. The largest source and sink terms are represented by precipitation and evapotranspiration, respectively. For water years 2002-06, a net surplus in the water budget of about 1.7 billion cubic feet was computed, where the inflows (precipitation, streamflow gains, inter-basin groundwater exchanges, well withdrawals/injection) exceeded outflows (evapotranspiration, streamflow losses, inter-basin losses, and well withdrawals/injection). The surplus inflow was balanced in the budget by an increase in storage by about the same amount. Groundwater withdrawals accounted for about 2 percent of the simulated outflow.

Simulated values of streamflow and groundwater levels from GSFLOW were compared to observations from 11 streamgages and 16 wells for water years 2000-06 during model calibration. Simulations of daily streamflow are considered acceptable for most streamgages except at the 
station Buffalo Run Lower. During wet years of high streamflow, the model slightly overestimated annual streamflow at most streamgages, and during dry years streamflow generally was slightly underestimated. The timing and magnitude of the simulated monthly mean streamflow corresponds closely to the observed streamflow. Simulations of mean monthly flow do not match the observations as closely as the daily and monthly mean streamflow calibration targets; at many of the streamgages, mean monthly flow was underestimated in March and April.

Transient groundwater levels, a lesser objective of calibration, were not adequately simulated at most observation wells. The timing and magnitude of the simulated groundwater-level fluctuations can only be considered acceptable for three wells used for calibration-CE 686, Centre Hall, and CE 692. The poor fit of the model to observed groundwater levels relative to the fit of the model to observed streamflows was not unexpected because the zone-based parameterization of the GSFLOW model is best suited for predictions that integrate large areas of the model domain (such as flux targets), whereas water-level targets are more local.

Differences in the magnitude and distribution of simulated net recharge between wet and dry periods were evaluated by comparing net recharge from water year 2001 (driest) to water year 2004 (wettest). Areas in the basin where rates of groundwater recharge are much higher than average and are capable of accepting substantially greater quantities of recharge during wet years might be considered critical for maintaining the flow of springs, stream base flow, or the source of water to supply wells. Areas where simulated rates of net recharge increased the most between the driest water year (2001) and wettest water year (2004) include the Scotia Barrens and valley floor between there and Bellefonte, along the toe slopes of Tussey and Bald Eagle Mountains, and some cells along Nittany Mountain.

The model is judged adequate for simulating the regional water budget; however, substantial errors between simulated and observed groundwater levels suggest that use of the maps of groundwater recharge should be limited to providing general information about the overall pattern and magnitude of spatial variability in recharge. The model could be used to compare simulations of historic conditions of climate or land use to alternative values for those conditions to help understand the effects of those alternative conditions on the water budget and groundwater recharge. As a planning tool, the model could be used to simulate the effects of future hypothetical changes at the basin scale.

An archive of the hydrologic model (including all GSFLOW files) is stored in the U.S. Geological Survey Pennsylvania Water Science Center digital model repository. The files are available upon request.

\section{References Cited}

Battaglin, W.A., Hay, L.E., Parker, R.S., and Leavesley, G.H., 1993, Applications of a GIS for modeling the sensitivity of water resources to alterations in climate in the Gunnison River basin, Colorado: Journal of the American Water Resources Association, v. 29, no. 6, p. 1021-1028. (available at http://dx.doi.org/10.1111/j.1752-1688.1993. tb03265.x.)

Becher, A.E., 1996, Ground-water resources of Cambrian and Ordovician carbonate rocks in the Valley and Ridge physiographic province of Pennsylvania: U.S. Geological Survey Open-File Report 90-109, 134 p.

Bjerklie, D.M., Starn, J.J., and Tamayo, Claudia, 2010, Estimation of the effects of land use and groundwater withdrawals on streamflow for the Pomperaug River, Connecticut: U.S. Geological Survey Scientific Investigations Report 2010-5114, $81 \mathrm{p}$.

Brachet, Florence, 2004, Regional groundwater modeling for source area delineation and recharge estimation: Master of Science Thesis in Civil Engineering, The Pennsylvania State University, Department of Civil and Environmental Engineering, $138 \mathrm{p}$.

Doherty, John, 2008, PEST surface water utilities: Brisbane, Australia, Watermark Numerical Computing and University of Idaho, 141 p., accessed September 28, 2011, at http:// www.pesthomepage.org/getfiles.php?file=swutils.pdf.

Doherty, J.E., 2010, PEST, Model-independent parameter estimation-User manual (5th ed., with additions): Brisbane, Australia, Watermark Numerical Computing.

Doherty, J.E., and Hunt, R.J., 2010, Approaches to highly parameterized inversion: A guide to using PEST for groundwater-model calibration: U.S. Geological Survey Scientific Investigations Report 2010-5169, 60 p.

Ely, D.M., Bachmann, M.P., and Vaccaro, J.J., 2011, Numerical simulation of groundwater flow for the Yakima River basin aquifer system, Washington: U.S. Geological Survey Scientific Investigations Report 2011-5155, 90 p.

Fulton, J.W., Koerkle, E.H., McAuley, S.D., Hoffman, S.A., and Zarr, L.F., 2005, Hydrogeologic setting and conceptual hydrologic model of the study basin, Centre County, Pennsylvania, June 2005: U.S. Geological Survey Scientific Investigations Report 2005-5091, 83 p. 
Gannett Fleming, Inc., 2008, Technical memorandum groundwater flow model results proposed Grove Quarry, Marion and Spring Townships, Centre County, Pennsylvania: Yardley, Pa., Gannett Fleming, Inc., 32 p.

Giddings, M.T., 1974, Hydrologic budget of Spring Creek Drainage Basin, Pennsylvania: University Park, Pa., The Pennsylvania State University, Ph.D. dissertation, 76 p., 2 pls., 13 figs.

Halford, K.J., and Hanson, R.T., 2002, User guide for the drawdown-limited, multi-node well (MNW) package for the U.S. Geological Survey's modular three-dimensional finite-difference ground-water flow model, versions MODFLOW-96 and MODFLOW-2000: U.S. Geological Survey Open-File Report 02-293, 33 p.

Harbaugh, A.W., 2005, MODFLOW-2005, the U.S. Geological Survey modular ground-water model-the Ground-Water Flow Process: U.S. Geological Survey Techniques and Methods 6-A16 [variously paged].

Horton, R.E., 1933, The role of infiltration in the hydrological cycle: American Geophysical Union transactions, v. 23, p. $479-482$.

Hill, M.C., and Tiedeman, C.R., 2007, Effective groundwater model calibration: Hoboken, N.J., Wiley-Interscience, $455 \mathrm{p}$.

Hunt, R.J., and Steuer, J.J., 2000, Simulation of the recharge area for Frederick Springs, Dane County, Wisconsin: U.S. Geological Survey Water-Resources Investigations Report 00-4172, 33 p.

Hunt, R.J., and Feinstein, D.T., 2012, MODFLOW-NWTRobust handling of dry cells using a Newton Formulation of MODFLOW-2005: Ground Water, v. 50, no. 4, p. 659-663.

Huntington, J.L., and Niswonger, R.G., 2012, Role of surfacewater and groundwater interactions on projected summertime streamflow in snow dominated regions: An integrated modeling approach: Water Resources Research, v. 48, W11524, doi:10.1029/2012WR012319.

Jeton, A.E., Dettinger, M.D., and Smith, J.L., 1996, Potential effects of climate change on streamflow, eastern and western slopes of the Sierra Nevada, California and Nevada: U.S. Geological Survey Water-Resources Investigations Report 95-4260, 44 p.

Jeton, A.E., and Maurer, D.K., 2007, Precipitation and runoff simulations of the Carson Range and Pine Nut Mountains, and updated estimates of ground-water inflow and the ground-water budget for basin-fill aquifers of Carson Valley, Douglas County, Nevada, and Alpine County, California: U.S. Geological Survey Scientific Investigations Report 2007-5205, 55 p. (Also available at http://pubs.usgs.gov/ $\operatorname{sir} / 2007 / 5205 /$.
Jeton, A.E., 2000, Precipitation-runoff simulations for the upper part of the Truckee River basin, California and Nevada: U.S. Geological Survey Water-Resources Investigations Report 99-4282, 41 p. (Also available at http://pubs. er.usgs.gov/usgspubs/wri/wri994282.)

Keating, E. and Zyvoloski, G., 2009, A stable and efficient numerical algorithm for unconfined aquifer analysis: Ground Water, v. 47, no. 4, p. 569-579.

Koczot, K.M., Jeton, A.E., McGurk, Bruce, and Dettinger, M.D., 2005, Precipitation-runoff processes in the Feather River basin, northeastern California, and streamflow predictability, water years 1971-97: U.S. Geological Survey Scientific Investigations Report 2004-5202, 92 p. (Also available at http://pubs.usgs.gov/sir/2004/5202/.)

Leavesley, G.H., Markstrom, S.L., Viger, R.J., and Hay, L.E., 2005, USGS Modular Modeling System (MMS)-Precipitation-Runoff Modeling System (PRMS) MMS-PRMS, in Singh, V., and Frevert, D., eds., Watershed Models: Boca Raton, Fla., CRC Press, p. 159-177.

Leavesley, G.H., and Stannard, L.G., 1995, The precipitationrunoff modeling system-PRMS, in Singh, V.P., ed., Computer models of watershed hydrology: Highlands Ranch, Colo., Water Resource Publications, p. 281-310.

Leavesley, G.H., Lichty, R.W., Troutman, B.M., and Saindon, L.G., 1983, Precipitation-runoff modeling system-User's manual: U.S. Geological Survey Water-Resources Investigations Report 83-4238, 207 p. (Also available at http:// pubs.er.usgs.gov/usgspubs/wri/wri834238.)

Lee, K.K., and Risley, J.C., 2001, Estimates of ground-water recharge, base flow, and stream reach gains and losses in the Willamette River Basin, Oregon: U.S. Geological Survey Water-Resources Investigations Report 01-4215, 52 p.

Lindsey, B.D., and Koch, M.L., 2004, Determining sources of water and contaminants to wells in a carbonate aquifer near Martinsburg, Blair County, Pennsylvania, by use of geochemical indicators, analysis of anthropogenic contaminants, and simulation of ground-water flow: U.S. Geological Survey Scientific Investigations Report 2004-5124, 46 p.

Markstrom, S.L., Niswonger, R.G., Regan, R.S., Prudic, D.E., Barlow, P.M., 2008, GSFLOW-Coupled Ground-water and surface-water flow model based on the integration of the Precipitation-Runoff Modeling System (PRMS) and the Modular Ground-Water Flow Model (MODFLOW-2005): U.S. Geological Survey Techniques and Methods, chap. 1, section D, book 6, $240 \mathrm{p}$.

Mejia, J.F., Huntington, J., Hatchett, B., Koracin, D., and Niswonger, R.G., 2012, Linking global climate models to an integrated hydrologic model: Using an individual station downscaling approach: Journal of Contemporary Water Research \& Education, issue 147, p. 17-27. 
Miller, I., and Freund, J. E., 1977, Probability and statistics for engineers: Englewood Cliffs, New Jersey, Prentice-Hall, $529 \mathrm{p}$.

Miller, D.A., and White, R.A., 1998, A conterminous United States multi-layer soil characteristics data set for regional climate and hydrology modeling: Earth Interactions, v. 2 (1998), paper no. 2, accessed December 1, 2008, at http:// ams.allenpress.com/archive/1087-3562/2/2/pdf/i1087-35622-2-1.pdf.

Moriasi, D.N., Arnold, J.G., Van Liew, M.W., Binger, R.L., Harmel, R.D., and Veith, T.L., 2007, Model evaluation guidelines for systematic quantification of accuracy in watershed simulations: American Society of Agricultural and Biological Engineers, v. 50, no. 3, p. 885-900.

Multi-Resolution Land Characteristics Consortium (MRLC), 2001, National land cover database, accessed October 1, 2007, at http://www.mrlc.gov/nlcd.php.

Nash, J. E., and J.V. Sutcliffe, 1970, River flow forecasting through conceptual models: Part 1. A discussion of principles: Journal of Hydrology v. 10, no. 3, p. 282-290.

Natural Resources Conservation Service, 2006, Soil Survey Geographic (SSURGO) Database: Natural Resources Conservation Service, accessed January 26, 2008, at http://soils. usda.gov/survey/geography/ .

Niswonger, R.G., Panday, Sorab, and Ibaraki, Motomu, 2011, MODFLOW-NWT, A newton formulation for MODFLOW-2005: U.S. Geological Survey Techniques and Methods 6-A37, $44 \mathrm{p}$.

Niswonger, R.G., Prudic, D.E., and Regan, R.S., 2006, Documentation of the Unsaturated-Zone Flow (UZF1) Package for modeling unsaturated flow between the land surface and the water table with MODFLOW-2005: U.S. Geological Techniques and Methods book 6, chap. A19, 62 p.

Niswonger, R.G. and Prudic, D.E., 2005, Documentation of the Streamflow-Routing (SFR2) Package to include unsaturated flow beneath streams-A modification to SFR1: U.S. Geological Survey Techniques and Methods book 6, chap. A13, 48 p.

Niswonger, R.G, Rassam, D., and Prudic, D.E., 2007, Assessing water resources using a new hydrologic model, accessed November 13, 2012, at http://www.mssanz.org.au/MODSIM07/papers/23_s31/AssessingWater_s31_Richard_.pdf.

Painter, S., Başağaoğlu, H., Liu, A.G., 2008, Robust representation of dry cells in single-layer MODFLOW models: Ground Water, v. 46, no. 6, p. 873-881.
PAMAP Program, 2008, Shaded Relief of Pennsylvania: The Pennsylvania Geospatial Data Clearinghouse, accessed 2008 at http://data1.commons.psu.edu/arcgis/services/ pasda/PAMAP_Hillshade/MapServer/WMSServer?request= 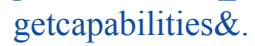

Parizek, R.R., 1984, Pollution potential of aquifers within the Centre Region, Centre County, Pennsylvania-Working element 2: State College, PA, report submitted to the Centre Regional Planning Commission, $71 \mathrm{p}$.

Parizek, R.R., and Filley, T.H., 1982, Abstract and maps from definitions of aquifers and confining beds within the Centre region: Center region aquifer study, part 1, Centre County, Pennsylvania: Centre Regional Planning Commission.

Parizek, R.R., White, W.B., and Langmuir, Donald, 1971, Hydrogeology and geochemistry of folded and faulted carbonate rocks of the central Appalachian type and related land use problems: Pennsylvania State University Circular 82 .

Pennsylvania Department of Conservation and Natural Resources, 2001, Digital bedrock geology of Pennsylvania, accessed October 1, 2007, at http://www.denr.state.pa.us/ topogeo/mapl/bedmap.aspx.

Pennsylvania Game Commission, 2011, State Game Lands: The Pennsylvania Geospatial Data Clearinghouse, accessed 2011, at http://data1.commons.psu.edu/arcgis/services/ pasda/PGC_StateGameland/MapServer/WMSServer?reques $\mathrm{t}=$ getcapabilities\&.

Pettyjohn, W.A., and Henning, R., 1979, Preliminary estimate of ground-water recharge rates, related streamflow and water quality in Ohio: Ohio State University Water Resources Center Project Completion Report Number 552, $241 \mathrm{p}$.

Pennsylvania State University, 2012, Living Filter Fact Sheet, accessed May 24, 2013, at http://www.opp.psu.edu/services/ eng-resources/living-filter-fact-sheet.

Poeter, E.P., Hill, M.C., Banta, E.R., Mehl, Steffen, and Christensen, Steen, 2005, UCODE_2005 and six other computer codes for universal sensitivity analysis, calibration, and uncertainty evaluation: U.S. Geological Survey Techniques and Methods, book 6, chap. A11, 283 p.

Richardson, David C., 2011, The Living Filter. Water Efficiency, accessed November 13, 2012, at http://www. waterefficiency.net/WE/Articles/The_Living_Filter_10553. aspx. 
Siddiqui, S.H., 1969, Hydrogeologic factors influencing well yields and aquifer hydraulic properties of folded and faulted carbonate rocks in central Pennsylvania: University Park, Pa., The Pennsylvania State University, Ph.D. dissertation, $502 \mathrm{p}$.

Sloto, R.A., and Crouse, M.Y., 1996, HYSEP-A computer program for hydrograph separation and analysis: U.S. Geological Survey Water-Resources Investigations Report 96-4040, $46 \mathrm{p}$.

Steuer, J.J., and Hunt, R.J., 2001, Use of a watershed-modeling approach to assess hydrologic effects of urbanization, North Fork Pheasant Branch Basin near Middleton, Wisconsin: U.S. Geological Survey Water-Resources Investigations Report 01-4113, 49 p.

Susquehanna River Basin Commission, 2005, Groundwater management plan for the Susquehanna River Basin: Susquehanna River Basin Commission Publication No. 236, $176 \mathrm{p}$.

Taylor, L.E., 1997, Water budget for the Spring Creek Basin: Harrisburg, Pa., Susquehanna River Basin Commission Publication 184, 19 p.

Todd Giddings and Associates, Inc., 1994, Design, refinement, and calibration of the Bald Eagle Deep Mine ground-water flow model, November 1994: State College, Pa., Todd Giddings and Associates, Inc., 22 p.

U.S. Department of Agriculture, Natural Resources Conservation Service, 1994, State soil geographic (STATSGO) database: U.S. Department of Agriculture, accessed June 13, 2005, at http://www.ncgc.nrsc.usda.gov/products/datasets/ STATSGO/.

U.S. Geological Survey, 1992, National land cover characterization project, accessed October 18, 2004, at http://landcover.usgs.gov/nationallandcover.asp.

U.S. Geological Survey, 2003, User's manual for the national water information system of the U.S. Geological Survey Automated Data Processing System (ADAPS): U.S. Geological Survey Open-File Report 03-123 version 4.3, 407 p.
U.S. Geological Survey, 2007, National Elevation Database, accessed October 1, 2007, at http://ned.usgs.gov.

U.S. Geological Survey, 2009, National Hydrography Dataset, accessed 2009, at http://nhd.usgs.gov.

U.S. Geological Survey, 2011, National Hydrography Dataset, accessed December 19, 2011, at http://nhd.usgs.gov/index. html.

Vaccaro, J.J., 1992, Sensitivity of groundwater recharge estimates to climate variability and change, Columbia Plateau, Washington: Journal of Geophysical Research, v. 97, no. D3, p. 2821-2833.

Viger, R.J., and Leavesley, G.H., 2007, The GIS Weasel user's manual: U.S. Geological Survey Techniques and Methods, book 6, chap. B4, 201 p. (Also available at http://pubs.usgs. gov/tm/2007/06B04/.)

Ward-Garrison, C., Markstrom, S.L., and Hay, L.E., 2009, Downsizer-A graphical user interface-based application for browsing, acquiring, and formatting time-series data for hydrologic modeling: U.S. Geological Survey Open-File Report 2009-1166, 27 p.

Waltman, W.J., Ciolkosz, E.J., Mausbach, M.J., Svoboda, M.D., Miller, D.A., and Kolb, P.J, 1997. Soil Climate Regimes of Pennsylvania, Bulletin No. 873: University Park, Pa., Pennsylvania State University Agricultural Experiment Station.

Westenbroek, S.M., Doherty, J.E., Walker, J.F., Kelson, V.A., Hunt, R.J., and Cera, T.B., 2012, Approaches in highly parameterized inversion: TSPROC, a general time-series processor to assist in model calibration and result summarization: U.S. Geological Survey Techniques and Methods, book 7, section C, chap. 7, 79 p.

Winston, R.B., 2000, Graphical User Interface for MODFLOW, version 4: U.S. Geological Survey Open-File Report 00-315, 27 p.

Wood, C.R., 1980, Summary groundwater resources of Centre County, Pennsylvania: Pennsylvania Geological Survey, 4th ser., Water Resources Report 48, 60 p. 
Tables 1 and 7 


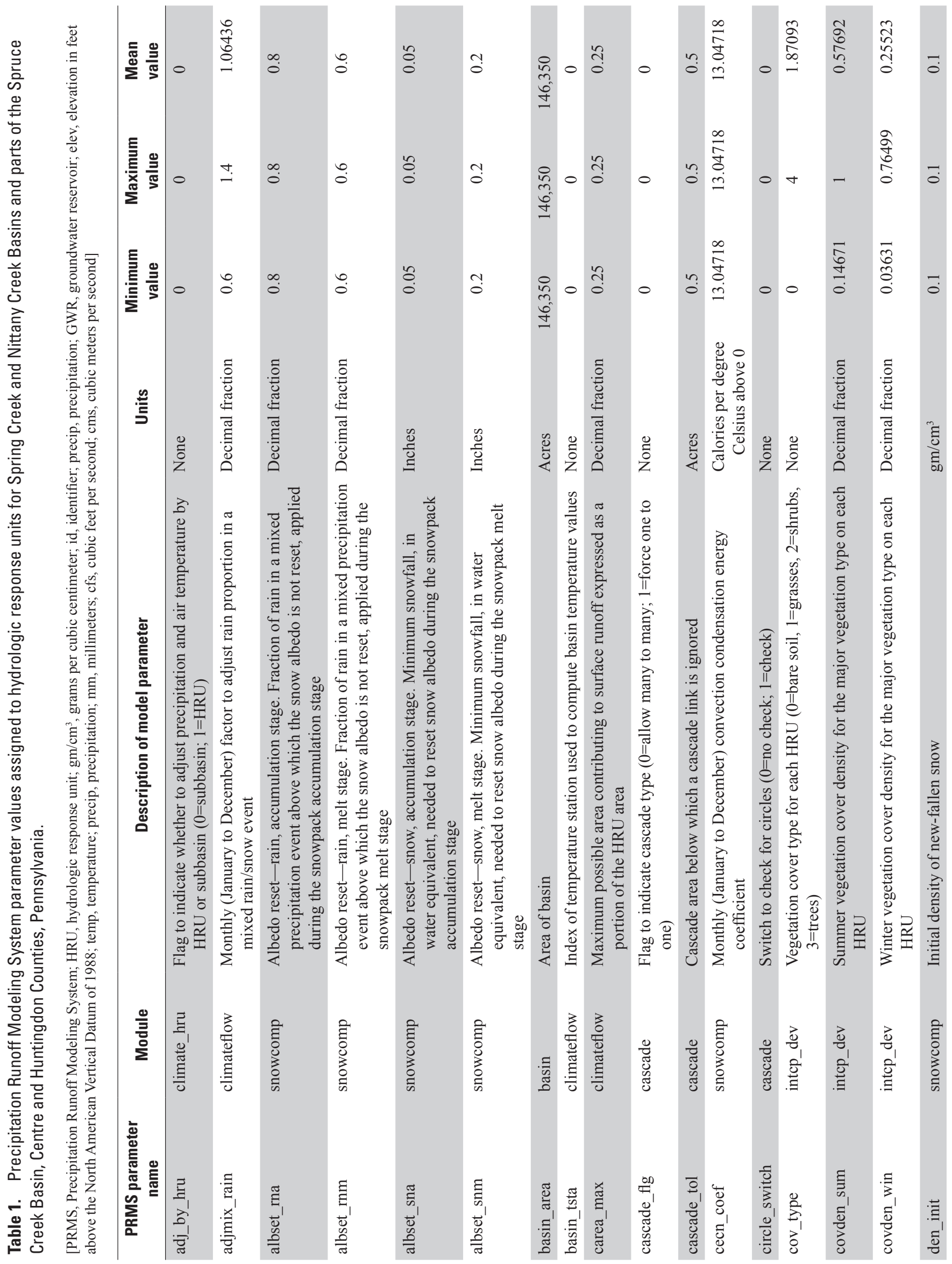




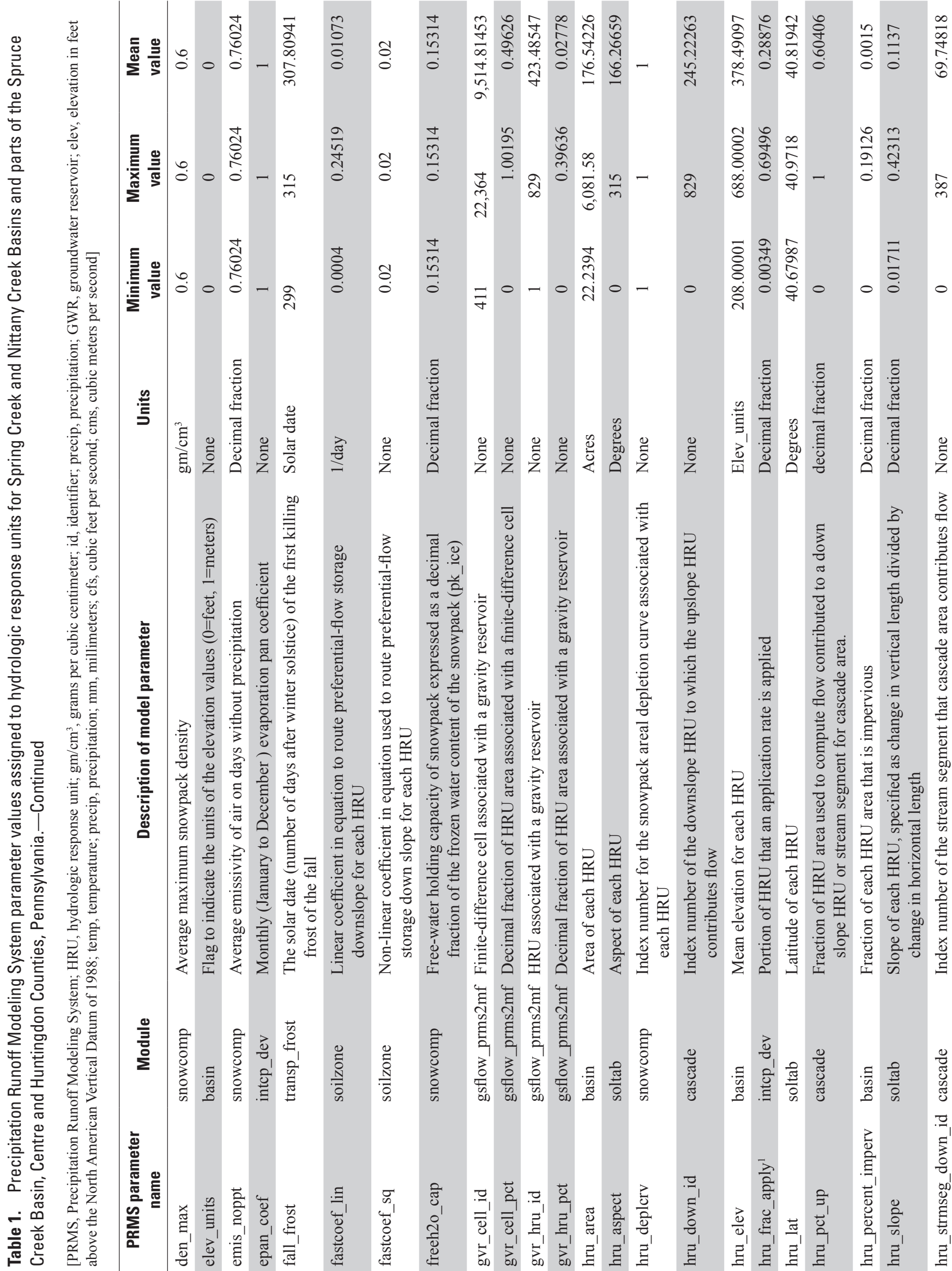




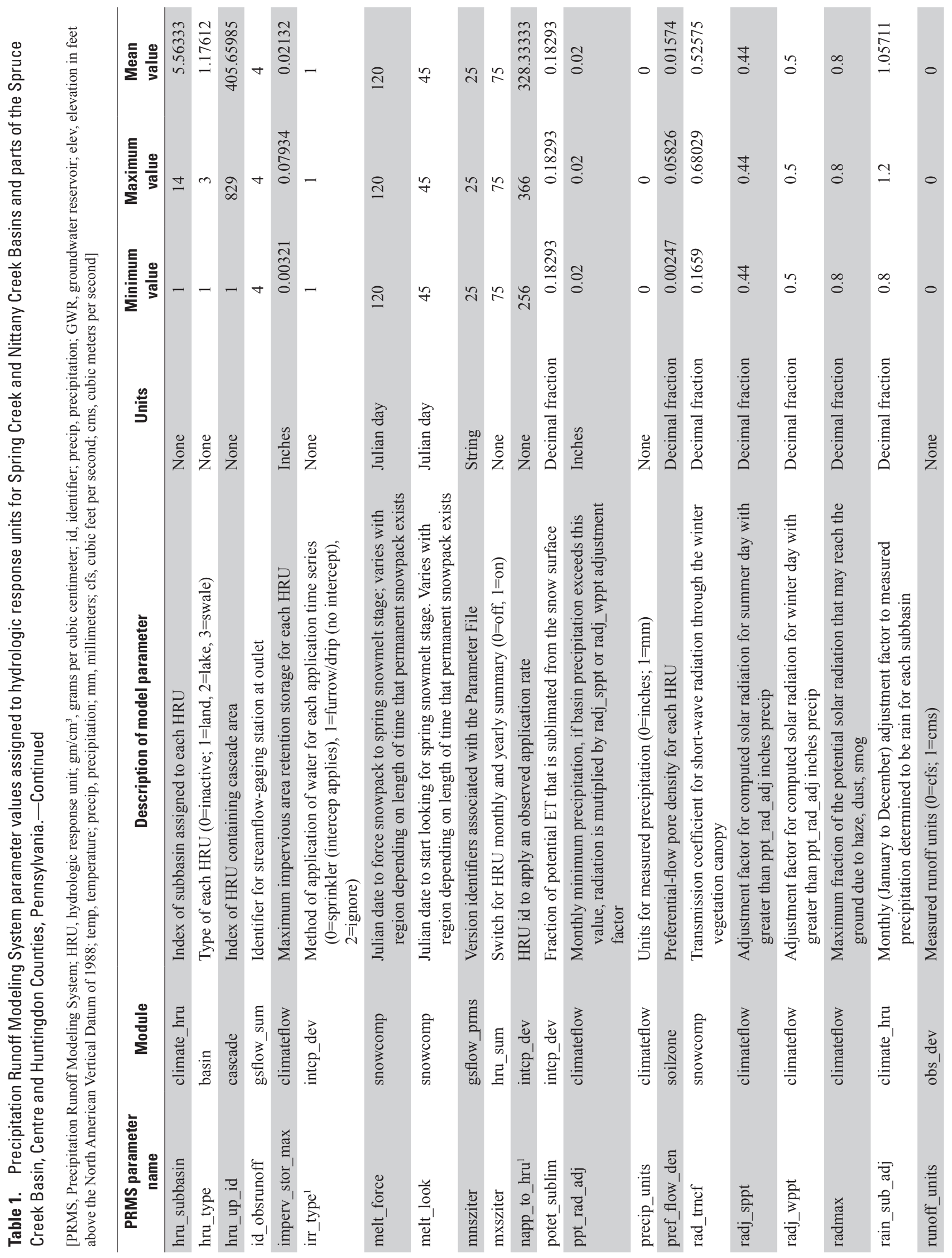




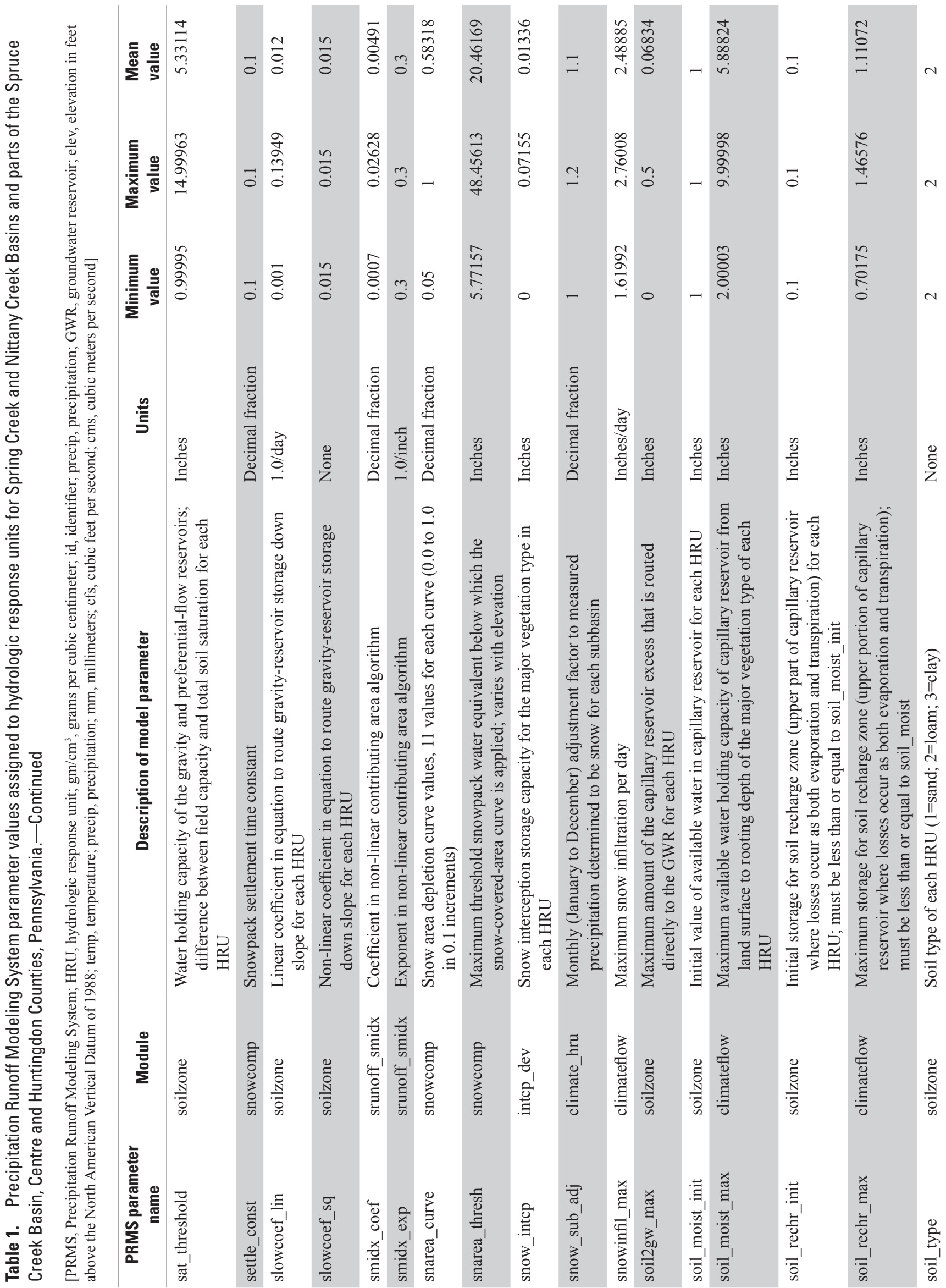




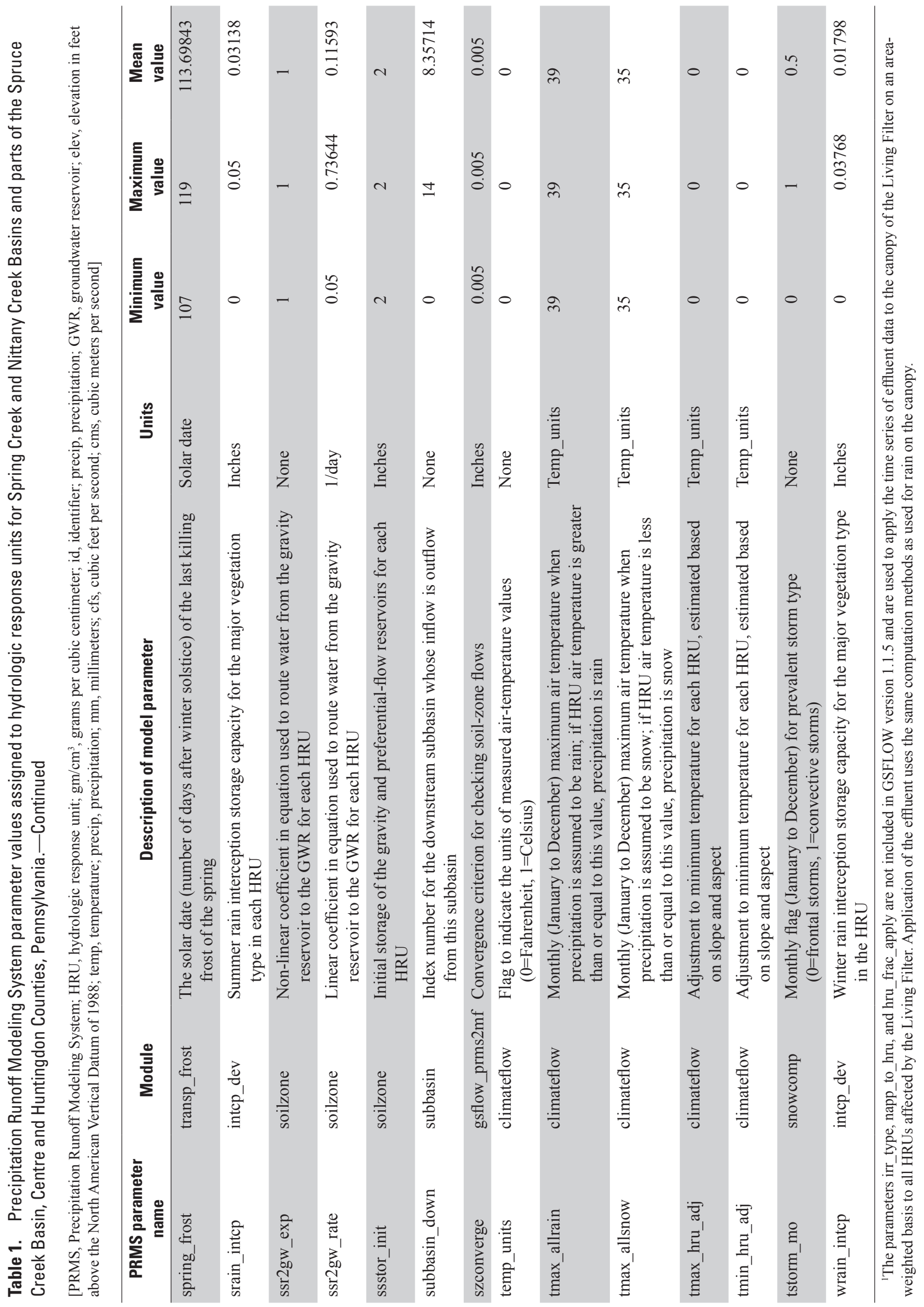




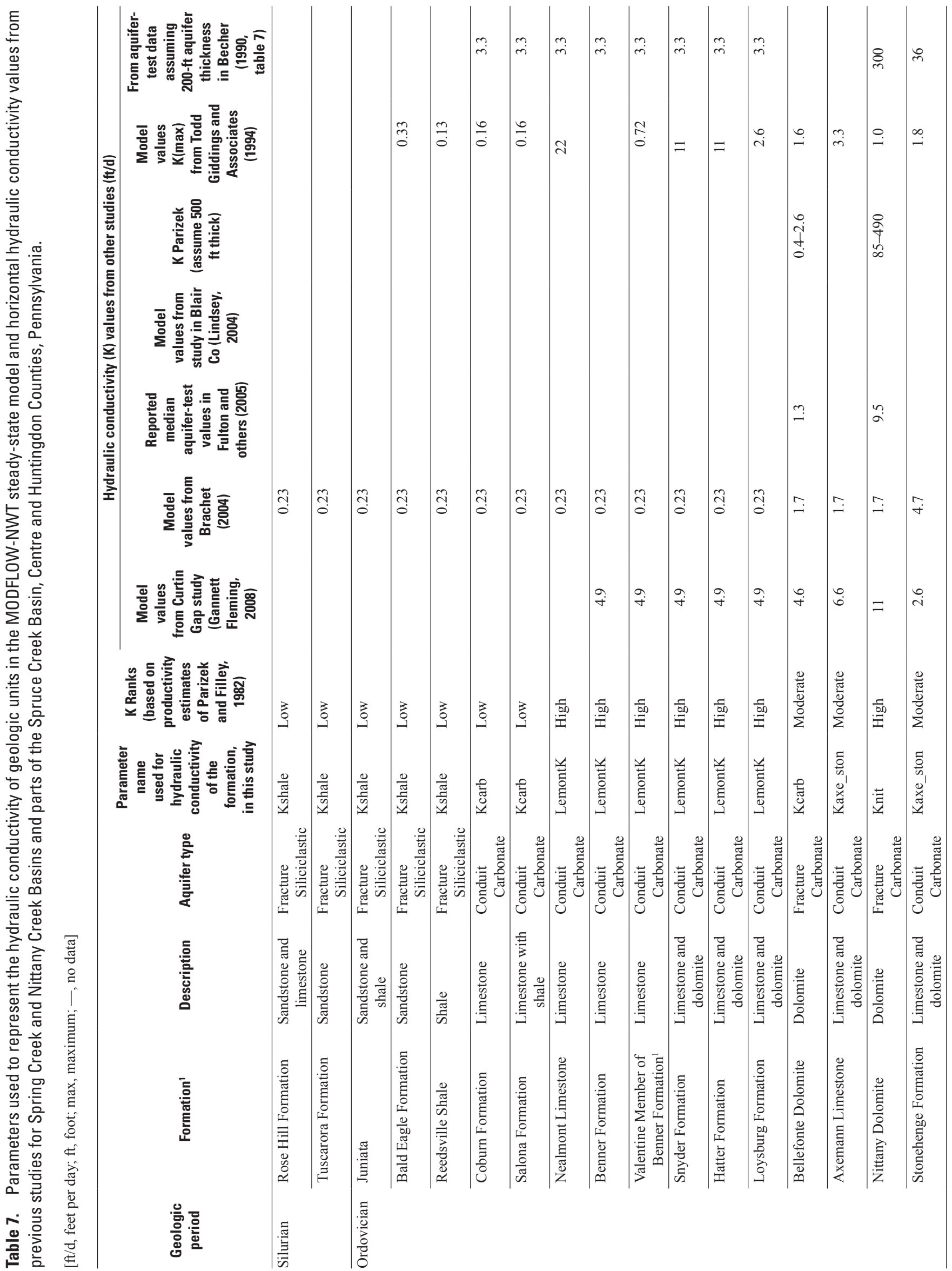




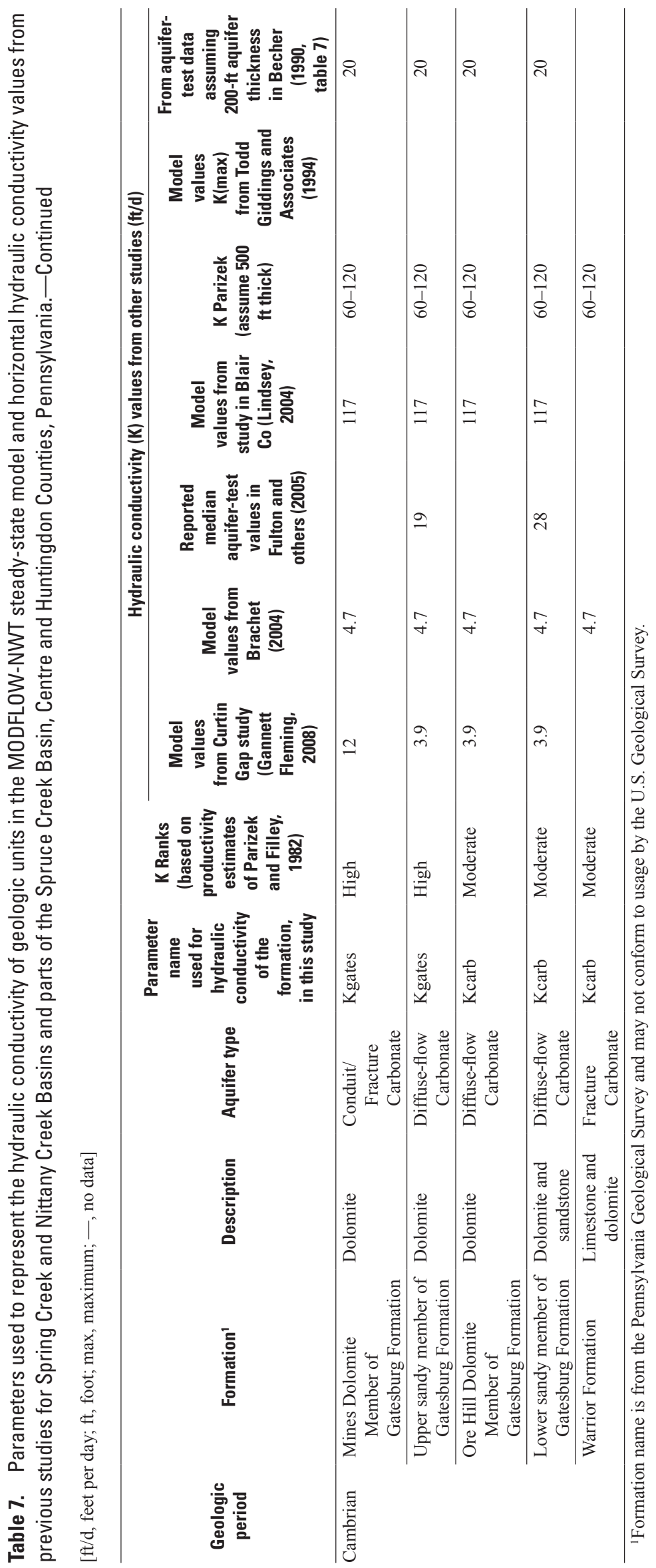


Appendix 


\section{Appendix. Results for All of the Calibration Targets for GSFLOW Simulations for Water Years 2000-06}

The results for all of the calibration targets for GSFLOW simulations for water years 2000-06 are presented in figures A1-A14. Comparisons are shown for natural log of daily mean streamflow (fig. A1), and annual and monthly streamflow and base flow (figs. A2-A12). Groundwater levels and annual mean water levels in observation wells are shown in figures A13 and A14. 


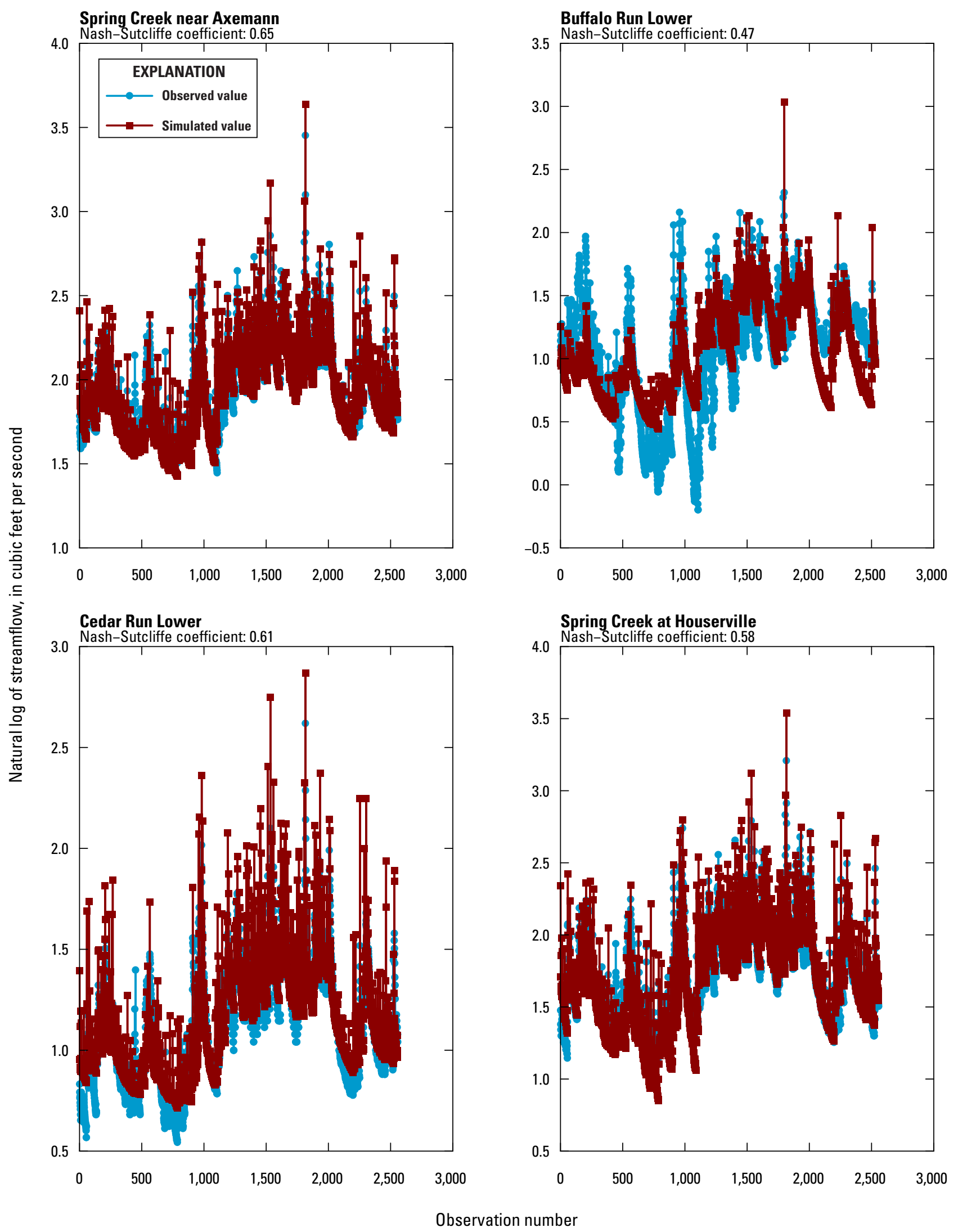

Figure A1. Observations and GSFLOW simulations of the natural log of daily streamflow at 11 streamgages in the Spring Creek and Nittany Creek Basins and parts of the Spruce Creek Basin, Centre and Huntingdon Counties, Pennsylvania, water years 2000-06. 


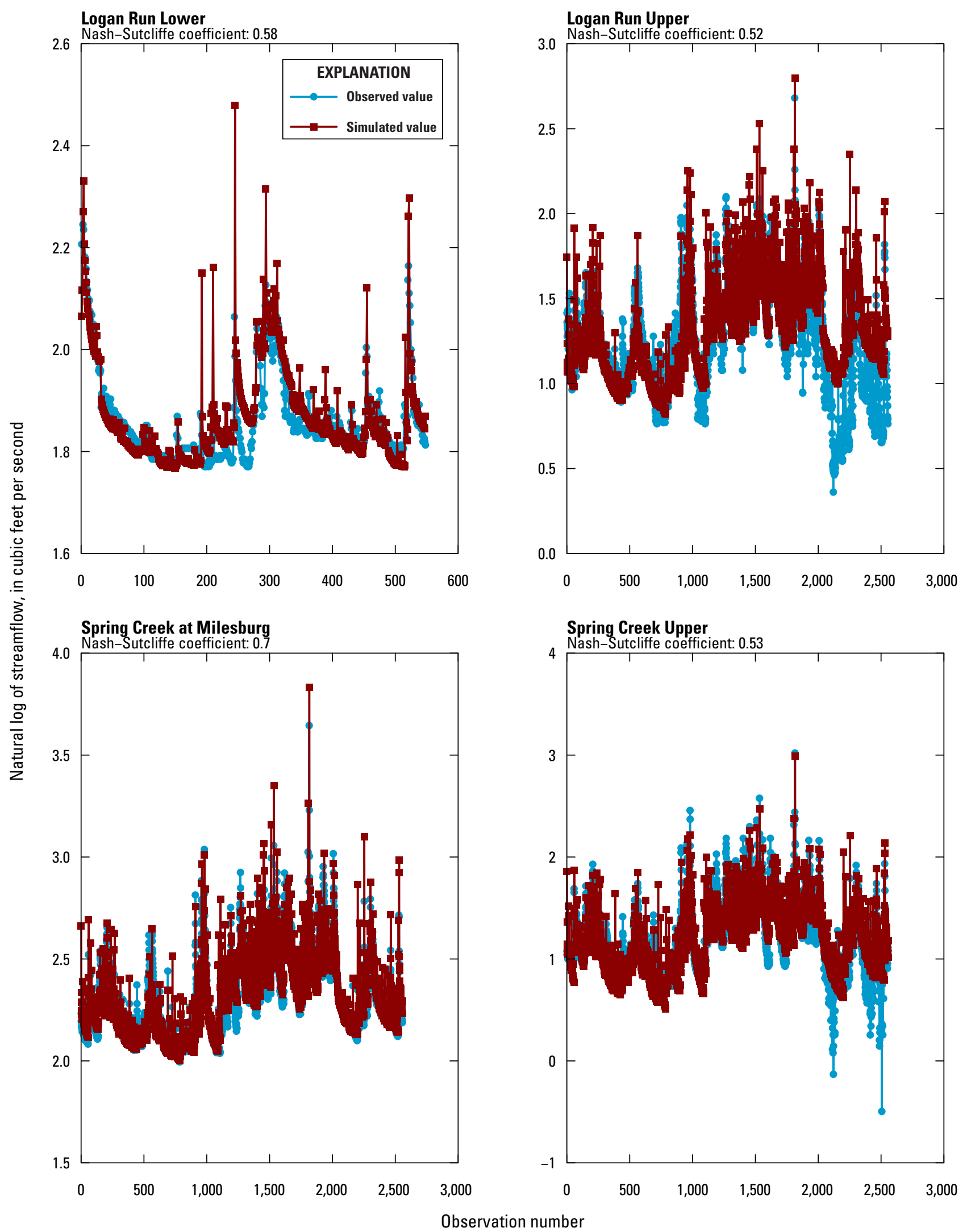

Figure A1. Observations and GSFLOW simulations of the natural log of daily streamflow at 11 streamgages in the Spring Creek and Nittany Creek Basins and parts of the Spruce Creek Basin, Centre and Huntingdon Counties, Pennsylvania, water years 2000-06.-Continued 


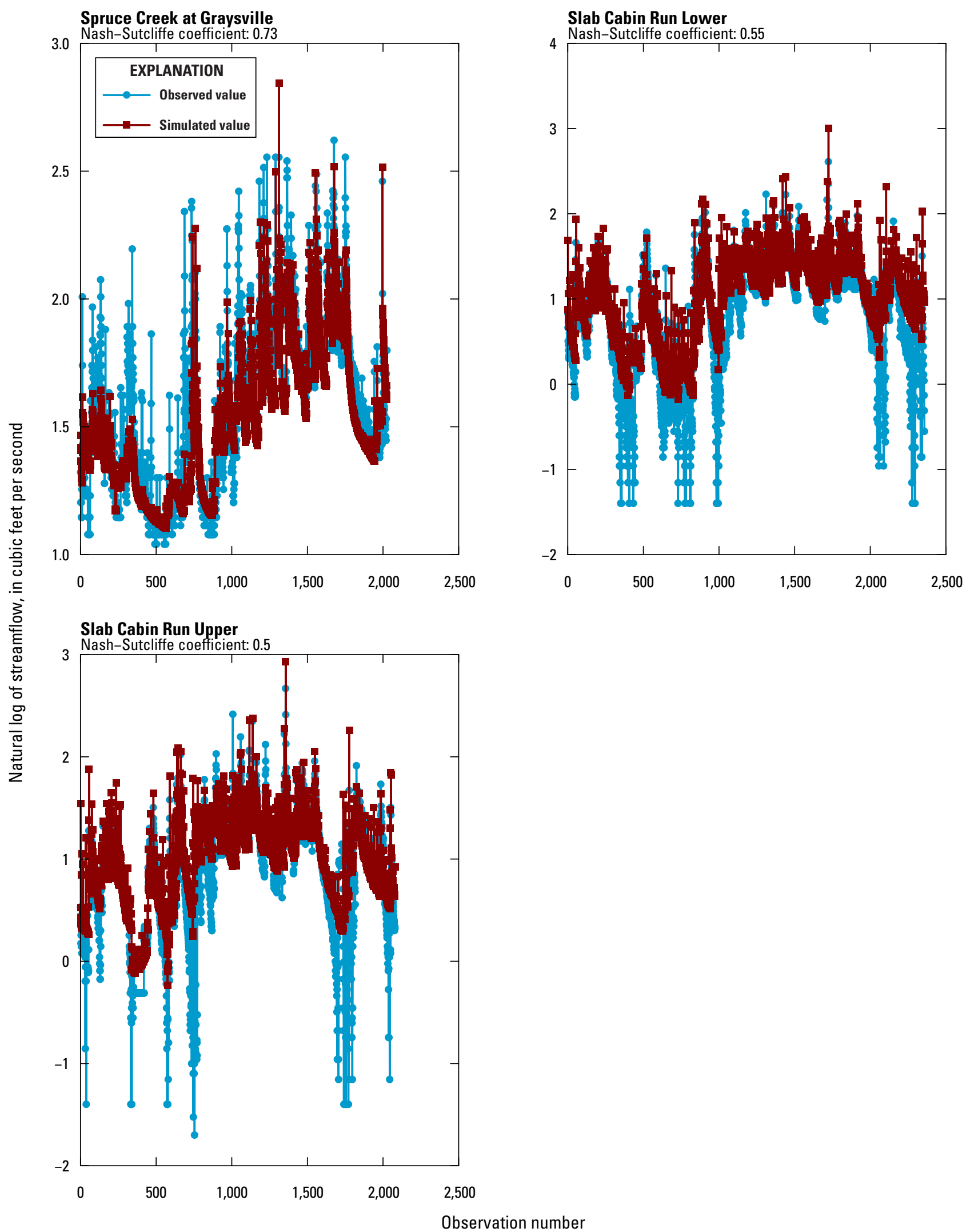

Figure A1. Observations and GSFLOW simulations of the natural log of daily streamflow at 11 streamgages in the Spring Creek and Nittany Creek Basins and parts of the Spruce Creek Basin, Centre and Huntingdon Counties, Pennsylvania, water years 2000-06.-Continued 


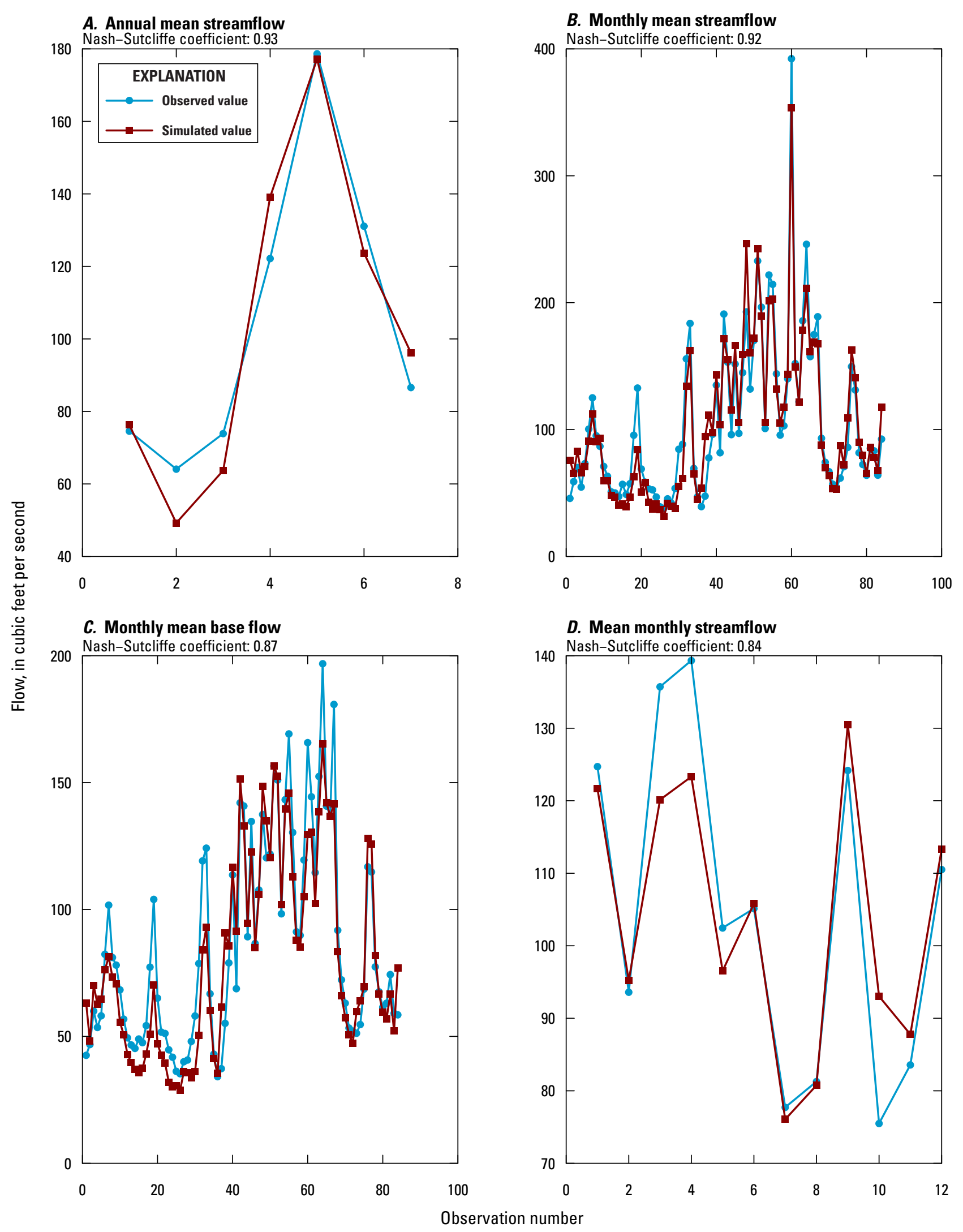

Figure A2. Observations and GSFLOW simulations of $A$, annual mean streamflow, $B$, monthly mean streamflow, $C$, monthly mean base flow, and $D$, mean monthly streamflow at Spring Creek near Axemann in the Spring Creek and Nittany Creek Basins and parts of the Spruce Creek Basin, Centre and Huntingdon Counties, Pennsylvania, water years 2000-06. 


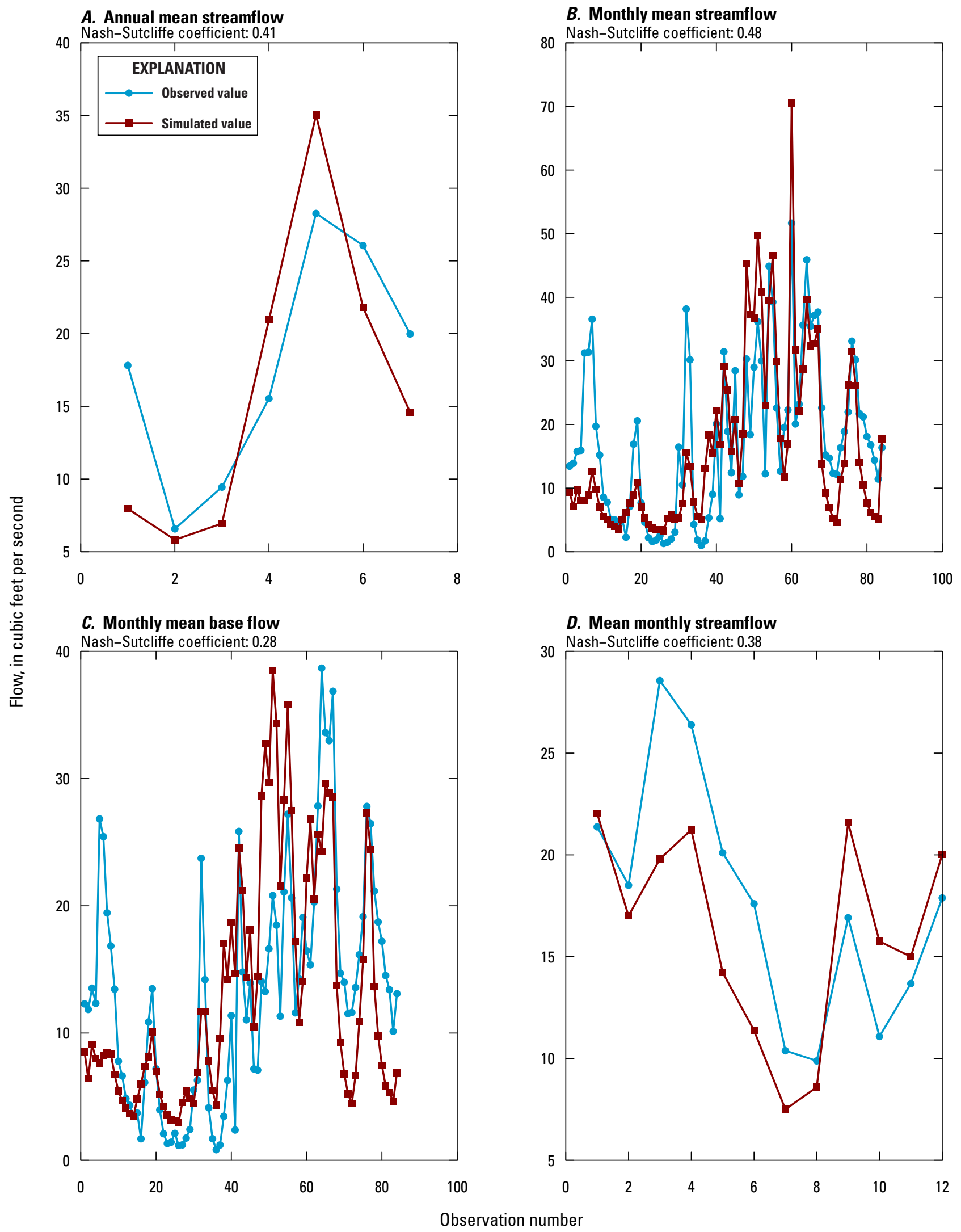

Figure A3. Observations and GSFLOW simulations of $A$, annual mean streamflow, $B$, monthly mean streamflow, $C$, monthly mean base flow, and $D$, mean monthly streamflow at Buffalo Run Lower in the Spring Creek and Nittany Creek Basins and parts of the Spruce Creek Basin, Centre and Huntingdon Counties, Pennsylvania, water years 2000-06. 


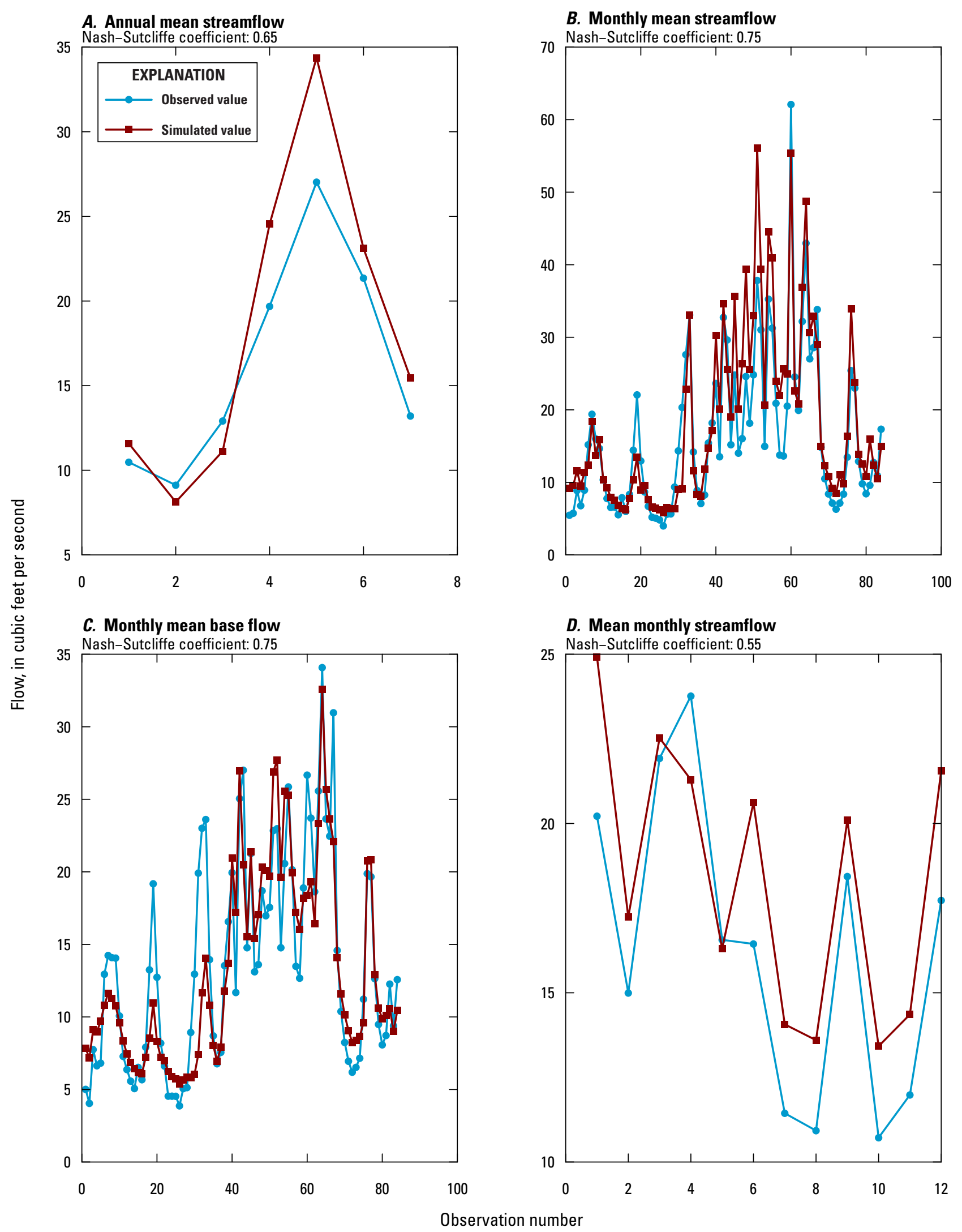

Figure A4. Observations and GSFLOW simulations of $A$, annual mean streamflow, $B$, monthly mean streamflow, $C$, monthly mean base flow, and $D$, mean monthly streamflow at Cedar Run Lower in the Spring Creek and Nittany Creek Basins and parts of the Spruce Creek Basin, Centre and Huntingdon Counties, Pennsylvania, water years 2000-06. 


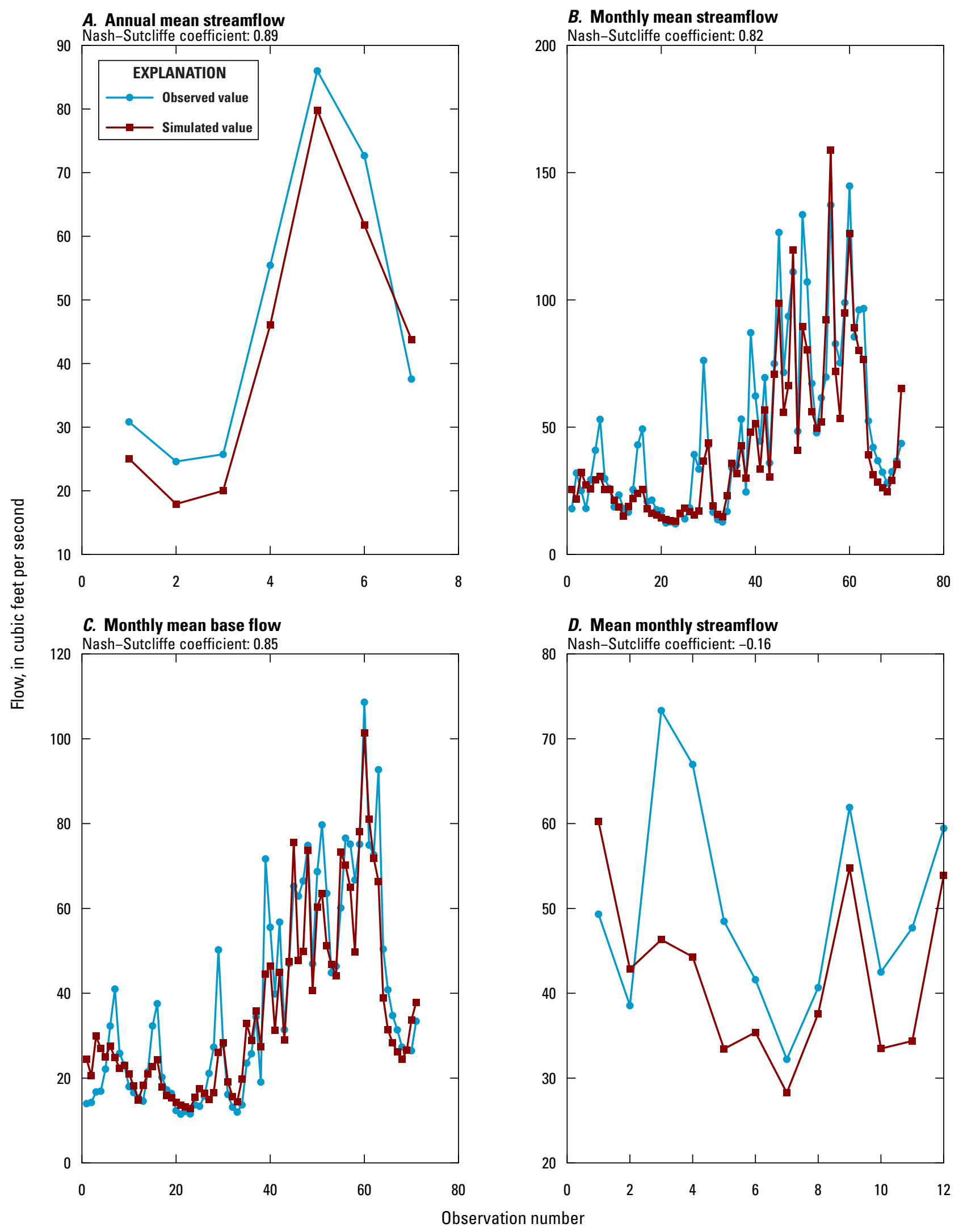

Figure A5. Observations and GSFLOW simulations of $A$, annual mean streamflow, $B$, monthly mean streamflow, $C$, monthly mean base flow, and $D$, mean monthly streamflow at Spruce Creek at Graysville in the Spring Creek and Nittany Creek Basins and parts of the Spruce Creek Basin, Centre and Huntingdon Counties, Pennsylvania, water years 2000-06. 


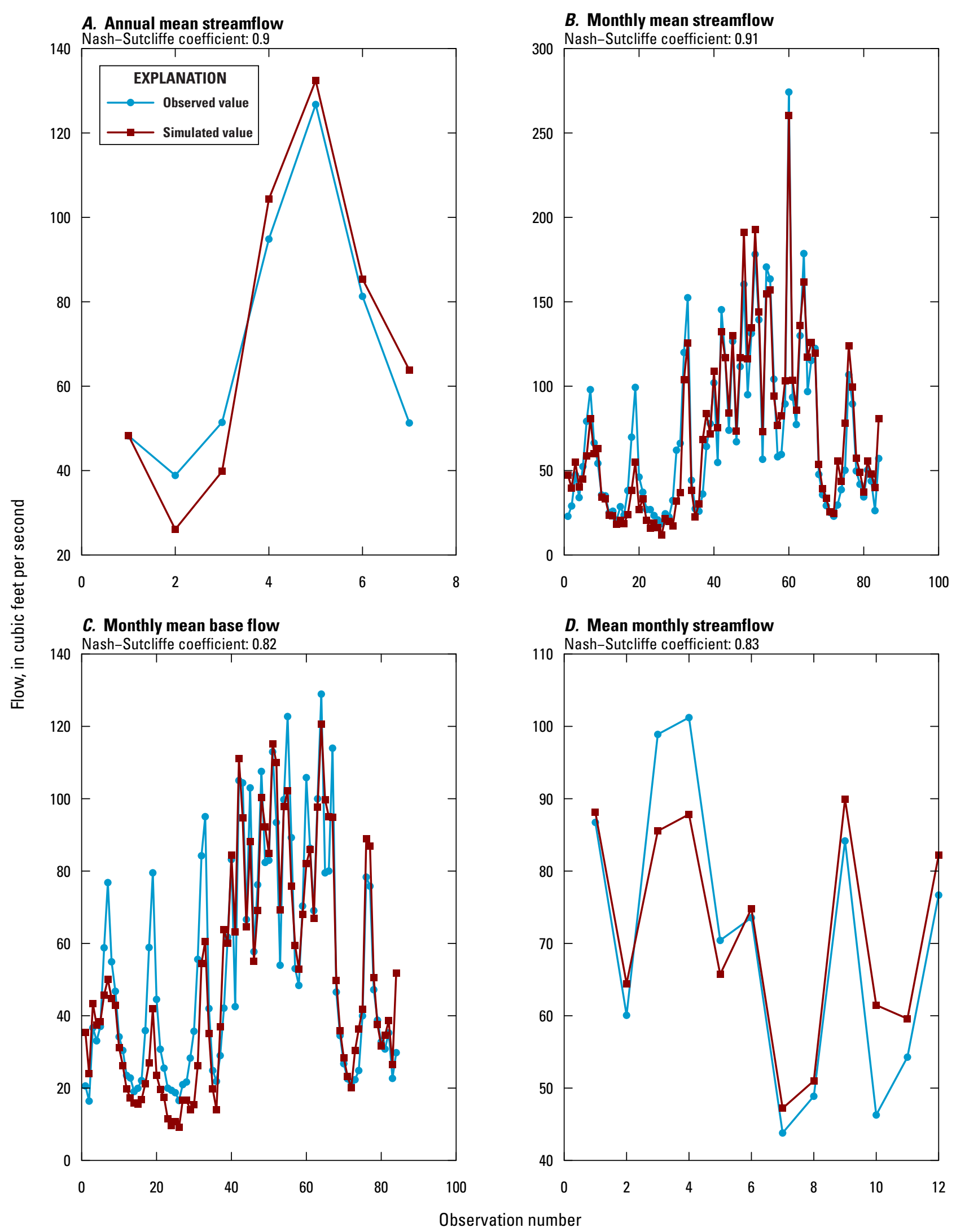

Figure A6. Observations and GSFLOW simulations of $A$, annual mean streamflow, $B$, monthly mean streamflow, $C$, monthly mean base flow, and $D$, mean monthly streamflow at Spring Creek at Houserville in the Spring Creek and Nittany Creek Basins and parts of the Spruce Creek Basin, Centre and Huntingdon Counties, Pennsylvania, water years 2000-06. 


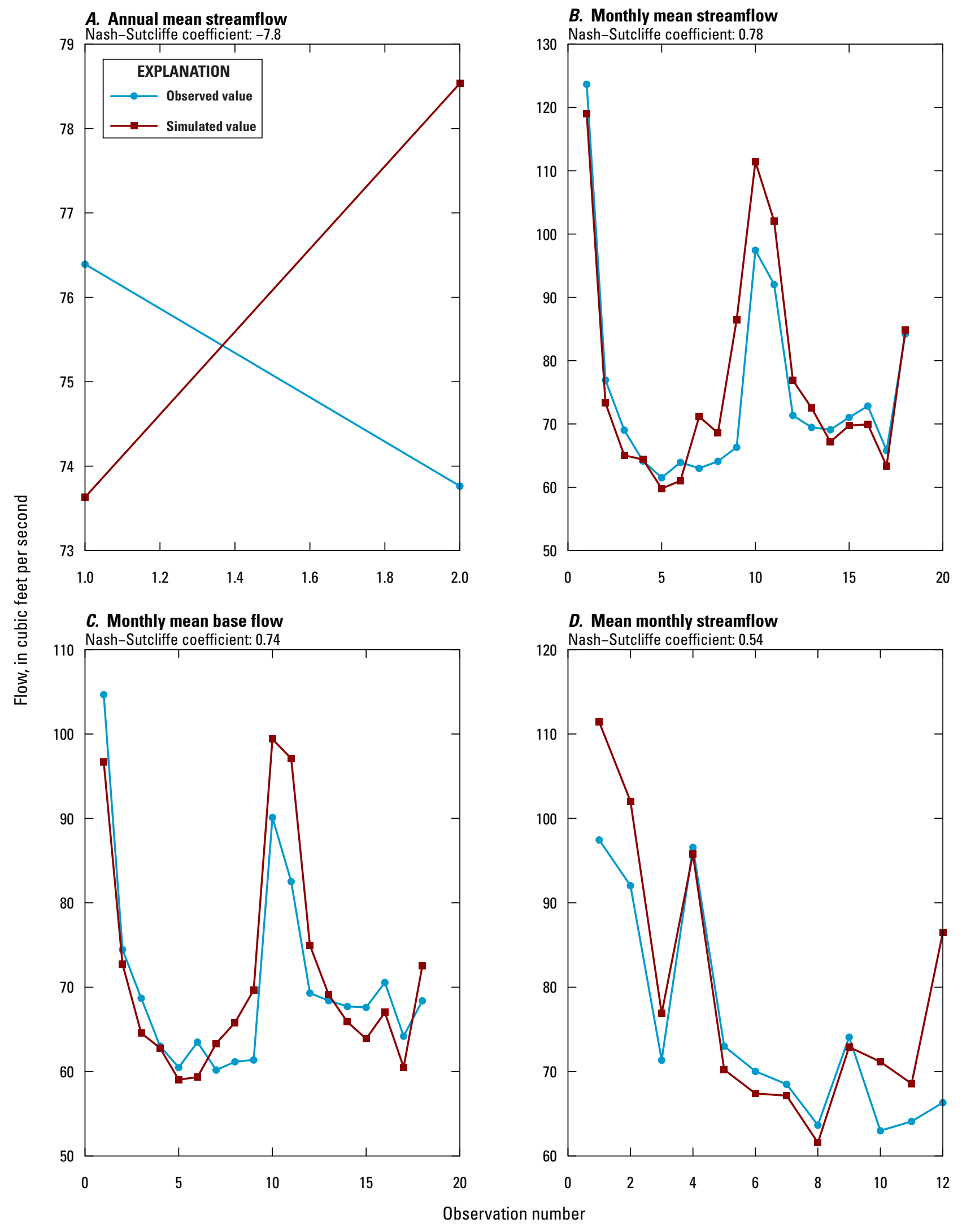

Figure A7. Observations and GSFLOW simulations of $A$, annual mean streamflow, $B$, monthly mean streamflow, $C$, monthly mean base flow, and $D$, mean monthly streamflow at Logan Branch Lower in the Spring Creek and Nittany Creek Basins and parts of the Spruce Creek Basin, Centre and Huntingdon Counties, Pennsylvania, water years 2000-06. 


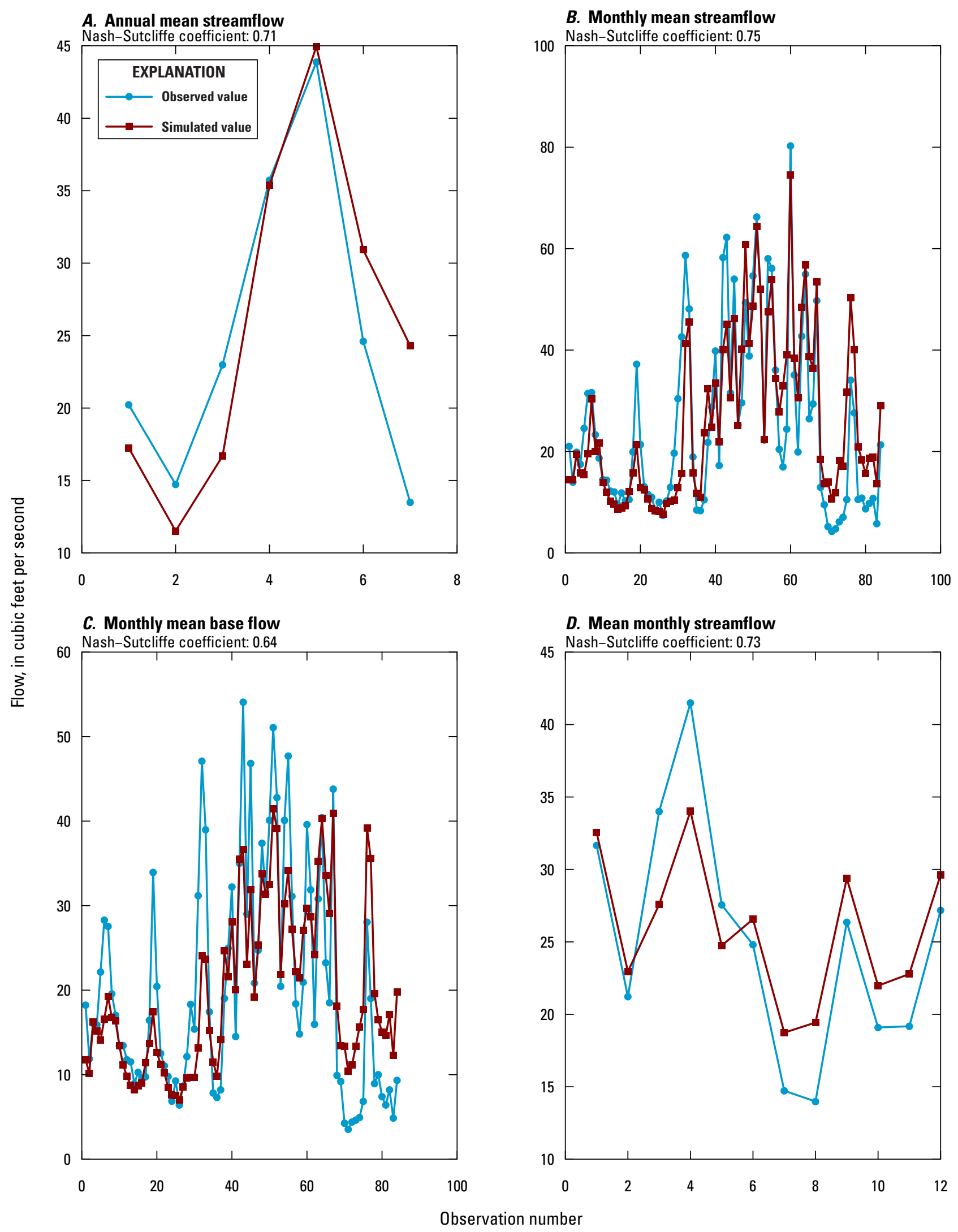

Figure A8. Observations and GSFLOW simulations of $A$, annual mean streamflow, $B$, monthly mean streamflow, $C$, monthly mean base flow, and $D$, mean monthly streamflow at Logan Branch Upper in the Spring Creek and Nittany Creek Basins and parts of the Spruce Creek Basin, Centre and Huntingdon Counties, Pennsylvania, water years 2000-06. 


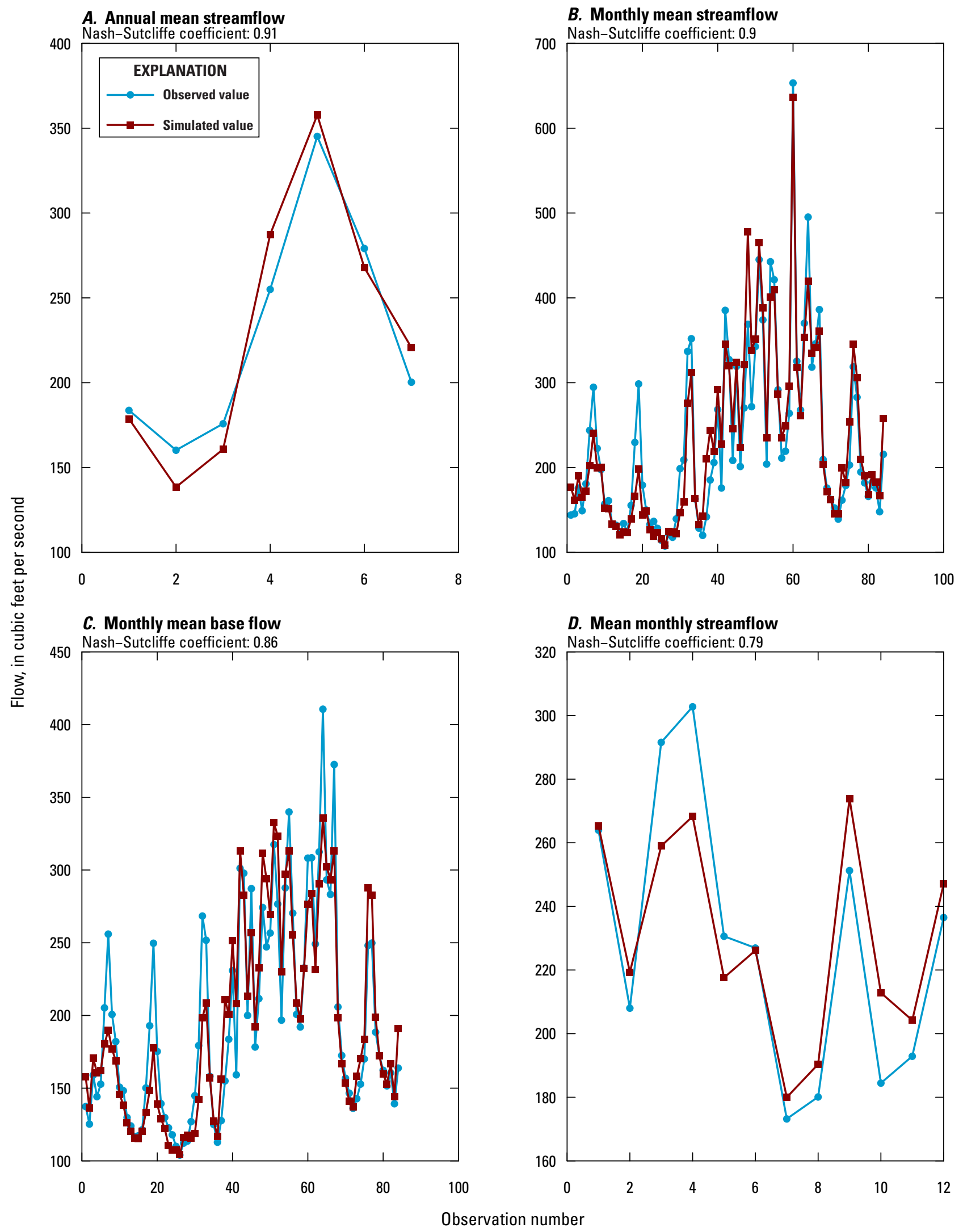

Figure A9. Observations and GSFLOW simulations of $A$, annual mean streamflow, $B$, monthly mean streamflow, $C$, monthly mean base flow, and $D$, mean monthly streamflow at Spring Creek at Milesburg in the Spring Creek and Nittany Creek Basins and parts of the Spruce Creek Basin, Centre and Huntingdon Counties, Pennsylvania, water years 2000-06. 


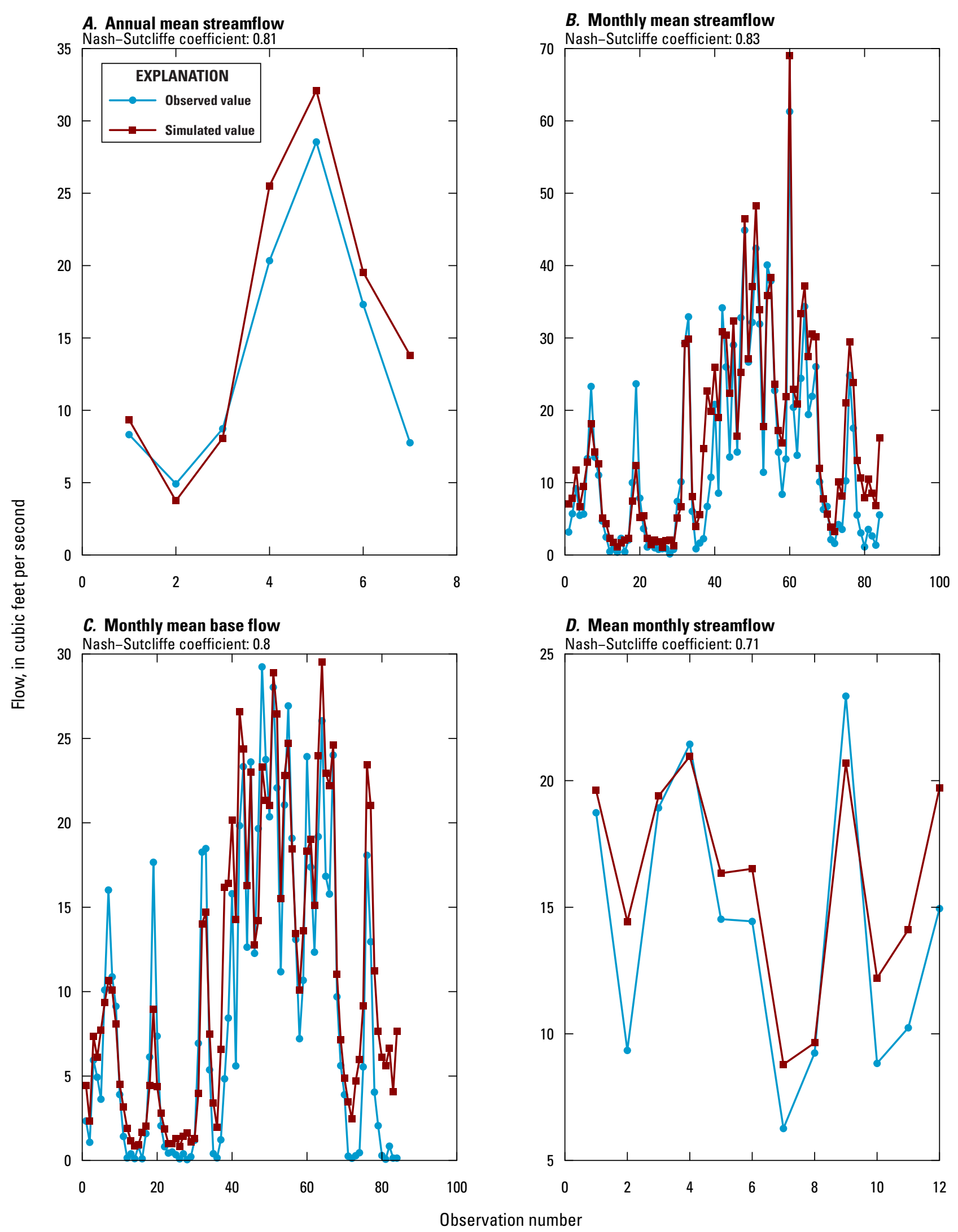

Figure A10. Observations and GSFLOW simulations of $A$, annual mean streamflow, $B$, monthly mean streamflow, $C$, monthly mean base flow, and $D$, mean monthly streamflow at Slab Cabin Run Lower in the Spring Creek and Nittany Creek Basins and parts of the Spruce Creek Basin, Centre and Huntingdon Counties, Pennsylvania, water years 2000-06. 


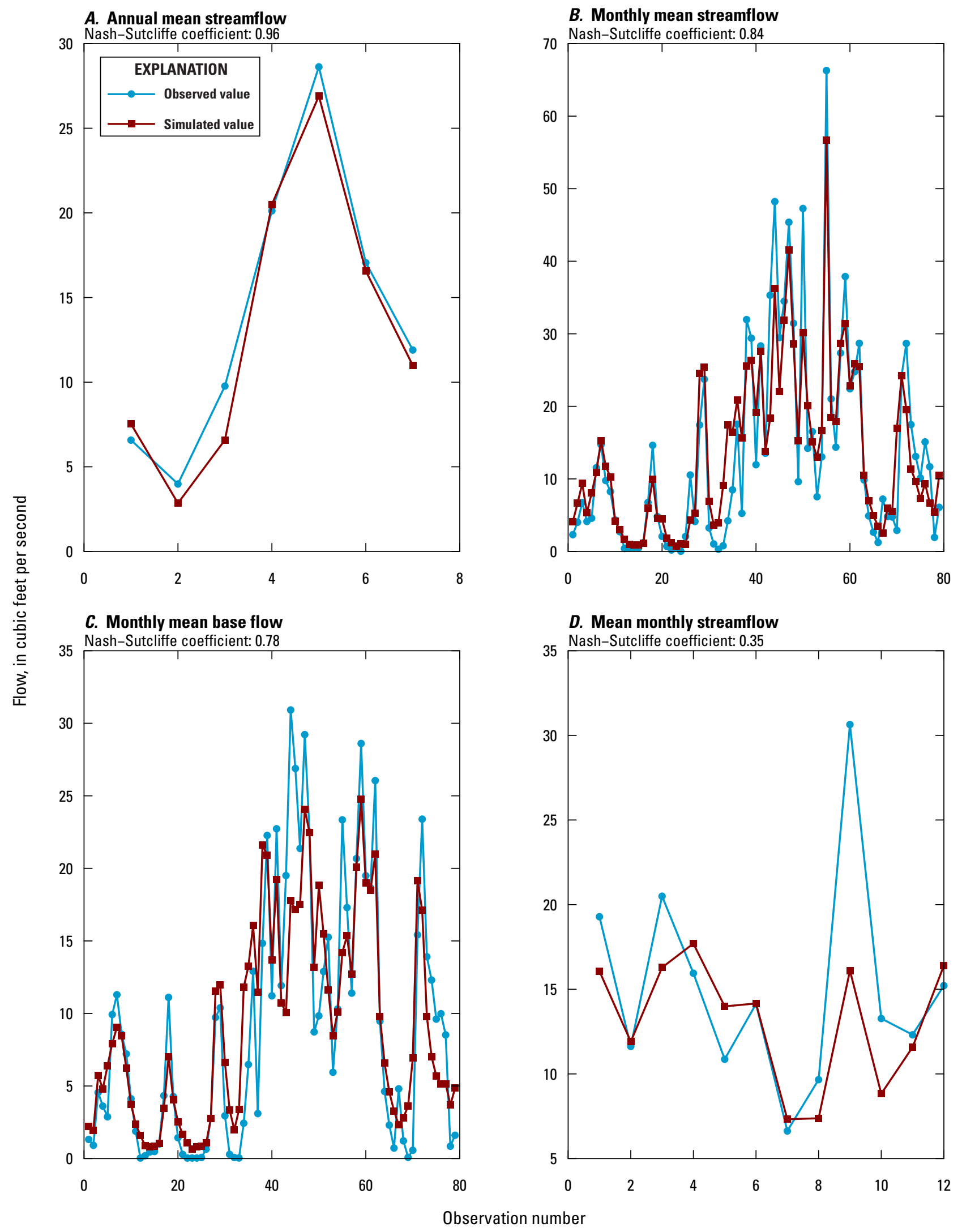

Figure A11. Observations and GSFLOW simulations of $A$, annual mean streamflow, $B$, monthly mean streamflow, $C$, monthly mean base flow, and $D$, mean monthly streamflow at Slab Cabin Run Upper in the Spring Creek and Nittany Creek Basins and parts of the Spruce Creek Basin, Centre and Huntingdon Counties, Pennsylvania, water years 2000-06. 


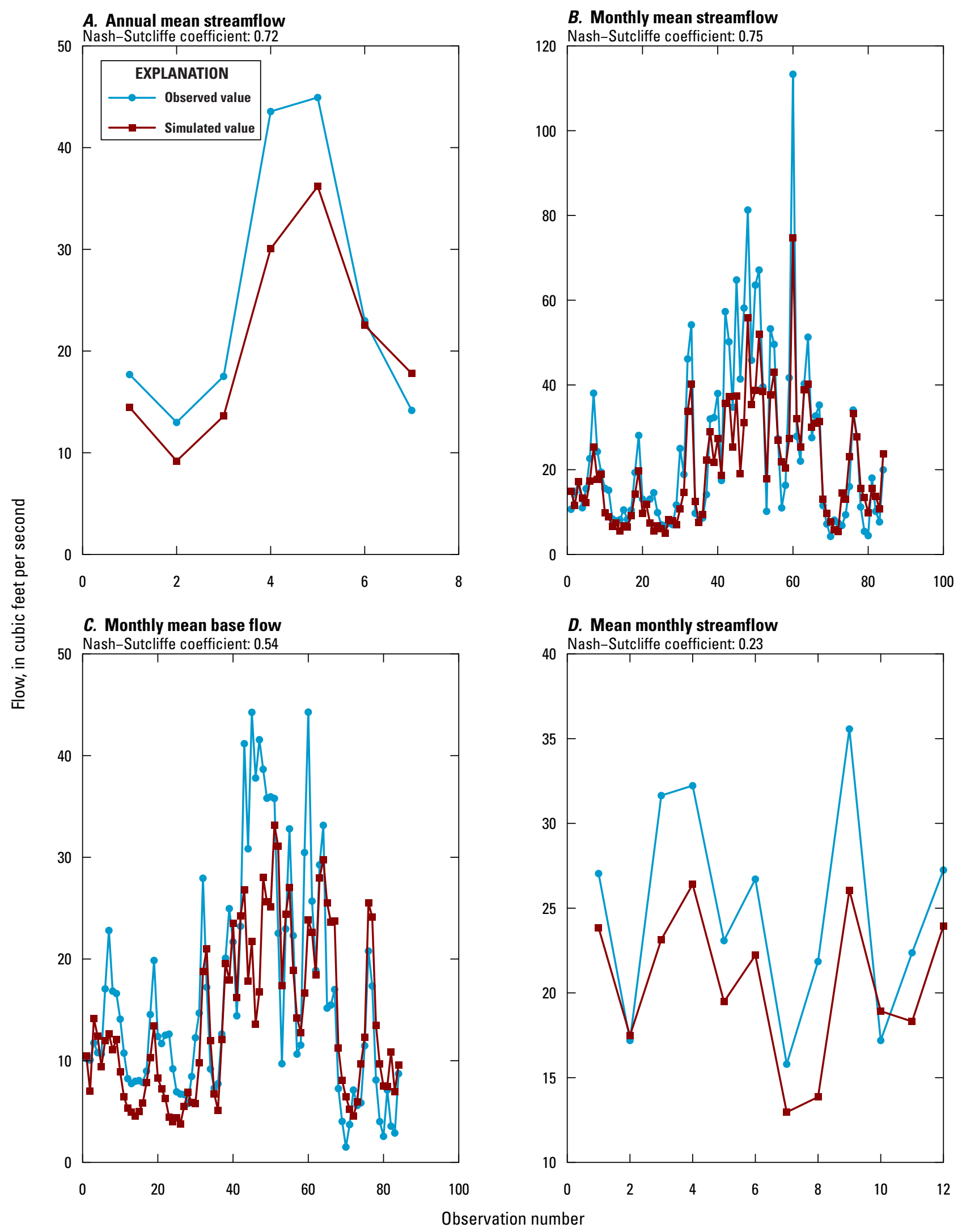

Figure A12. Observations and GSFLOW simulations of $A$, annual mean streamflow, $B$, monthly mean streamflow, $C$, monthly mean base flow, and $D$, mean monthly streamflow at Spring Creek Upper in the Spring Creek and Nittany Creek Basins and parts of the Spruce Creek Basin, Centre and Huntingdon Counties, Pennsylvania, water years 2000-06. 
FILMORE

Nash-Sutcliffe coefficient: -39

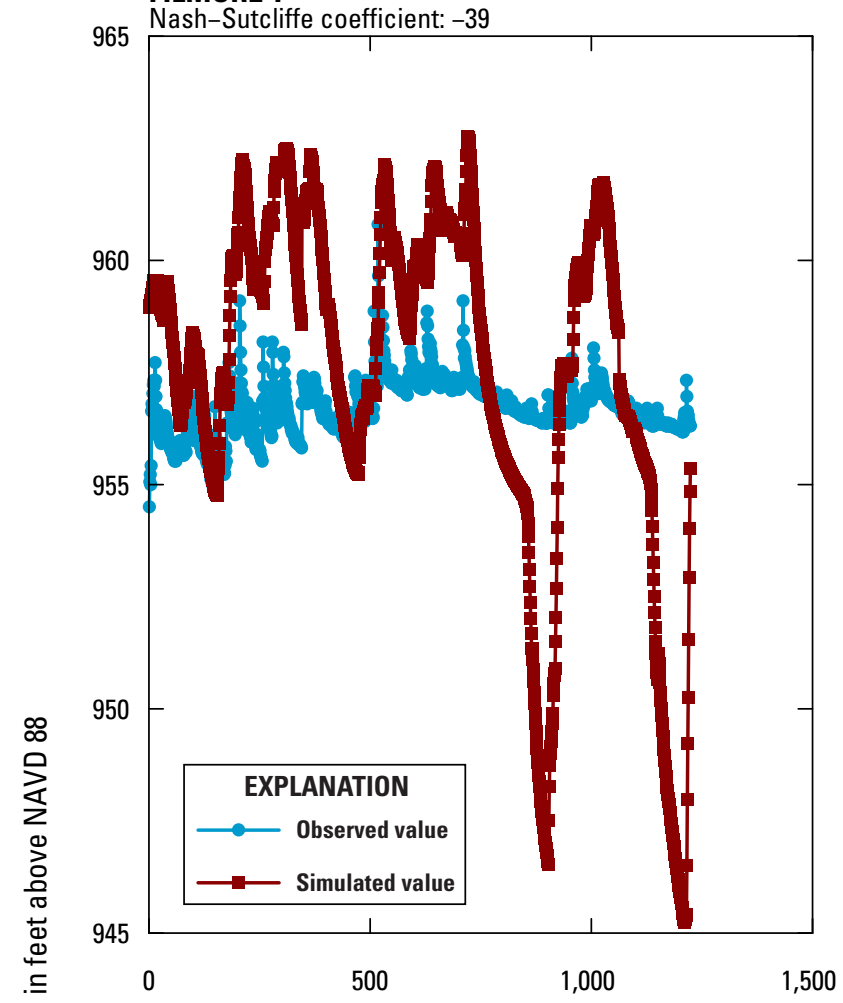

$$
1,620 \text { Nash-Sutcliffe coefficient: }-7.4
$$

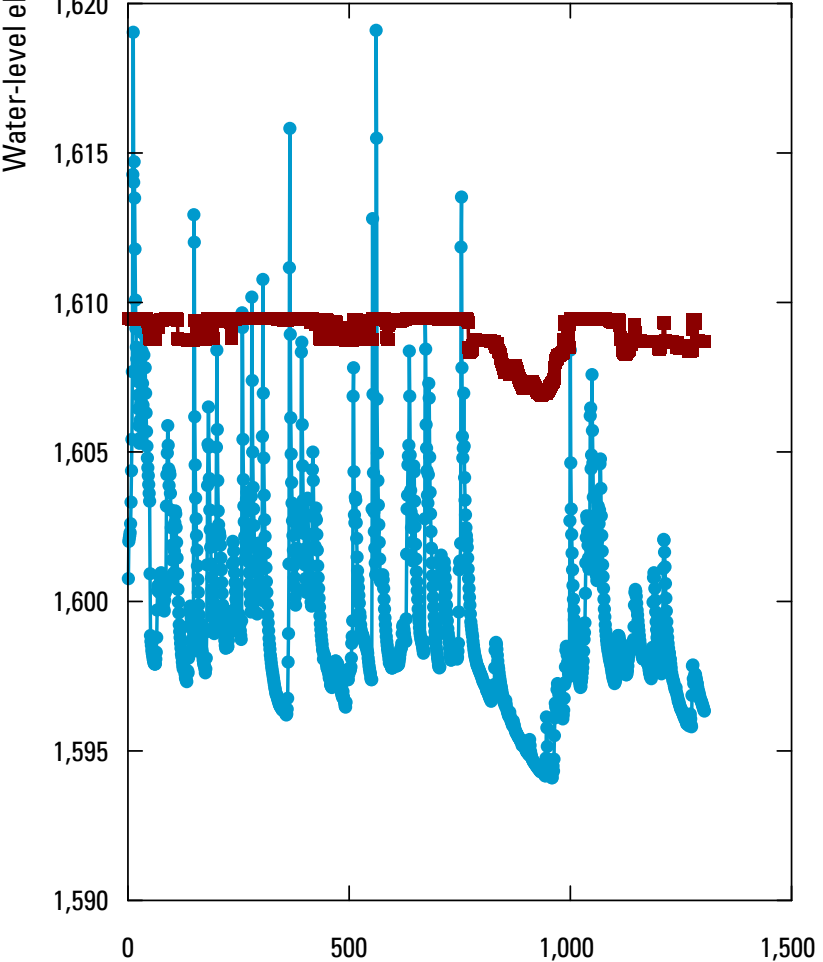

CE686

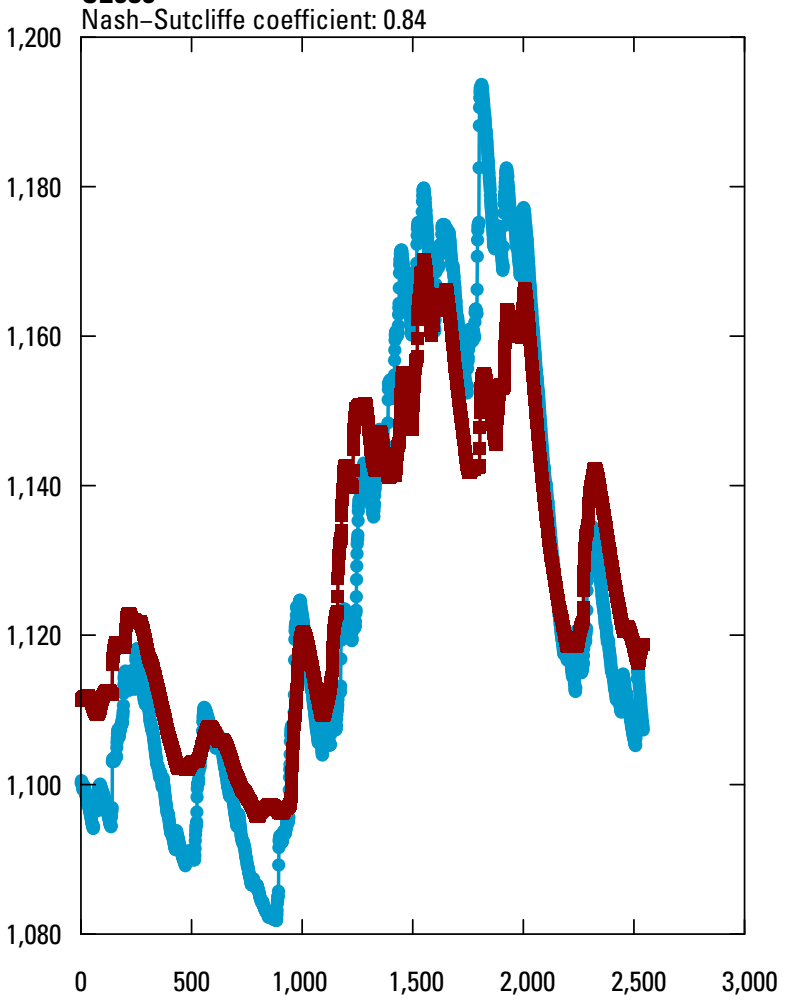

BIG HOLLOW

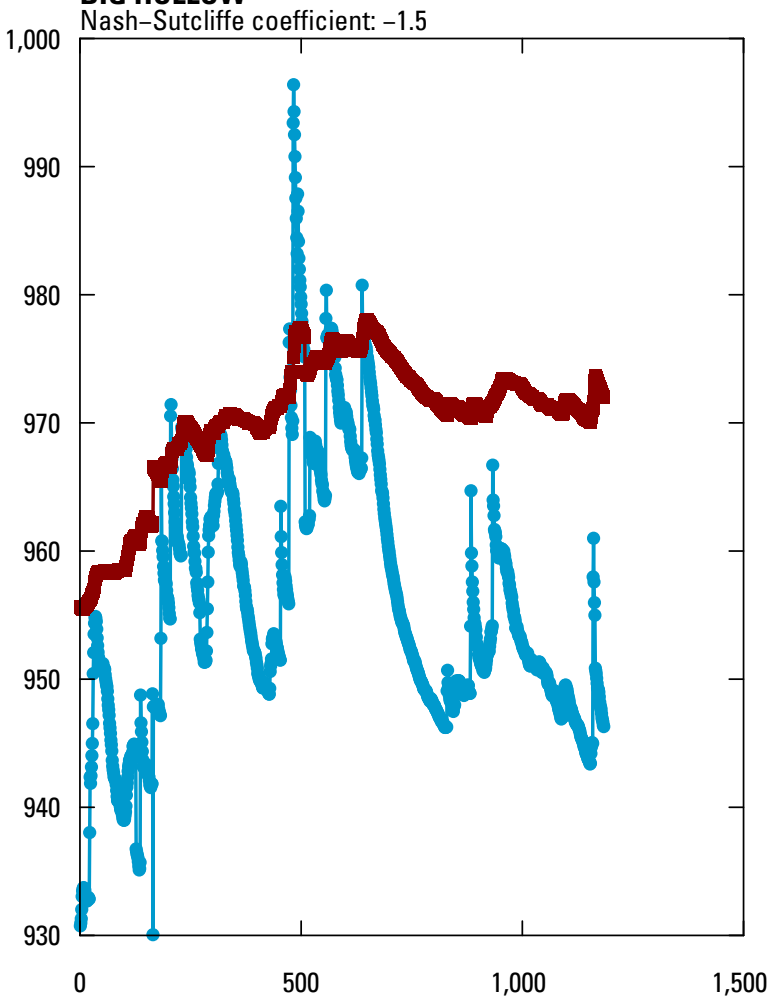

Observation number

Figure A13. Observations and GSFLOW simulations of groundwater levels in selected wells in the Spring Creek and Nittany Creek Basins and parts of the Spruce Creek Basin, Centre and Huntingdon counties, Pennsylvania, water years 2000-06. 


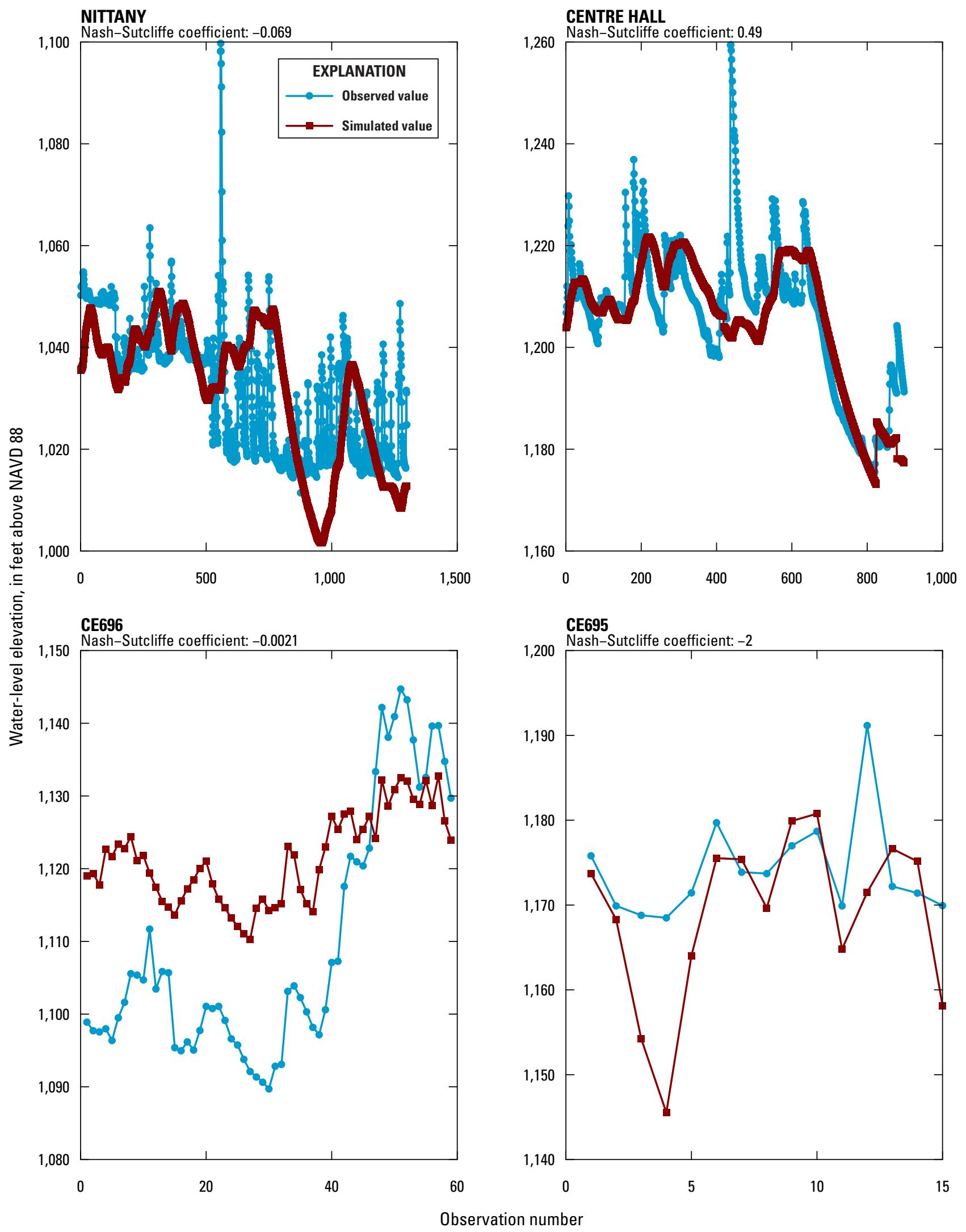

Figure A13. Observations and GSFLOW simulations of groundwater levels in selected wells in the Spring Creek and Nittany Creek Basins and parts of the Spruce Creek Basin, Centre and Huntingdon counties, Pennsylvania, water years $\approx 2000-06$. - Continued 


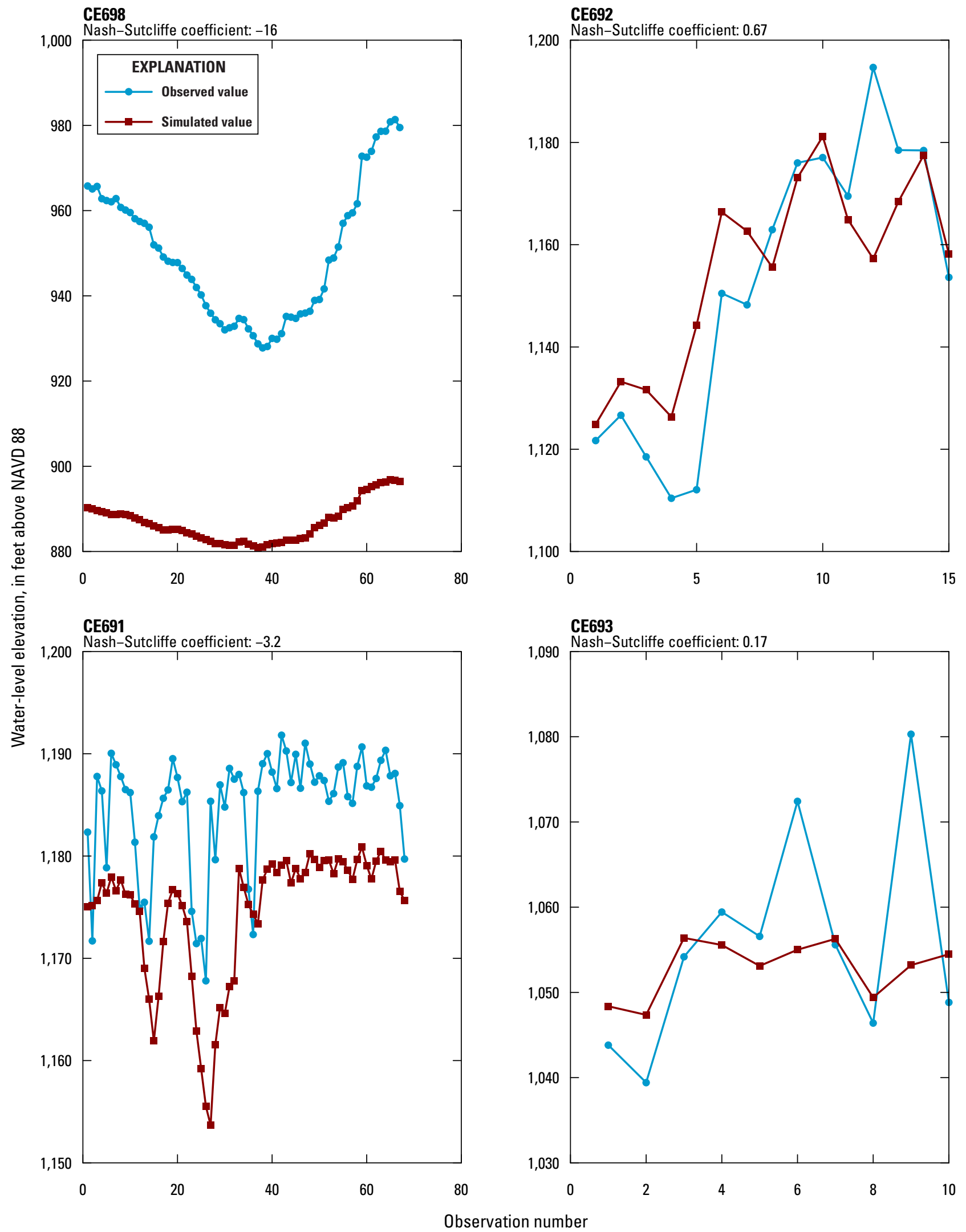

Figure A13. Observations and GSFLOW simulations of groundwater levels in selected wells in the Spring Creek and Nittany Creek Basins and parts of the Spruce Creek Basin, Centre and Huntingdon counties, Pennsylvania, water years $\approx 2000-06$. - Continued 


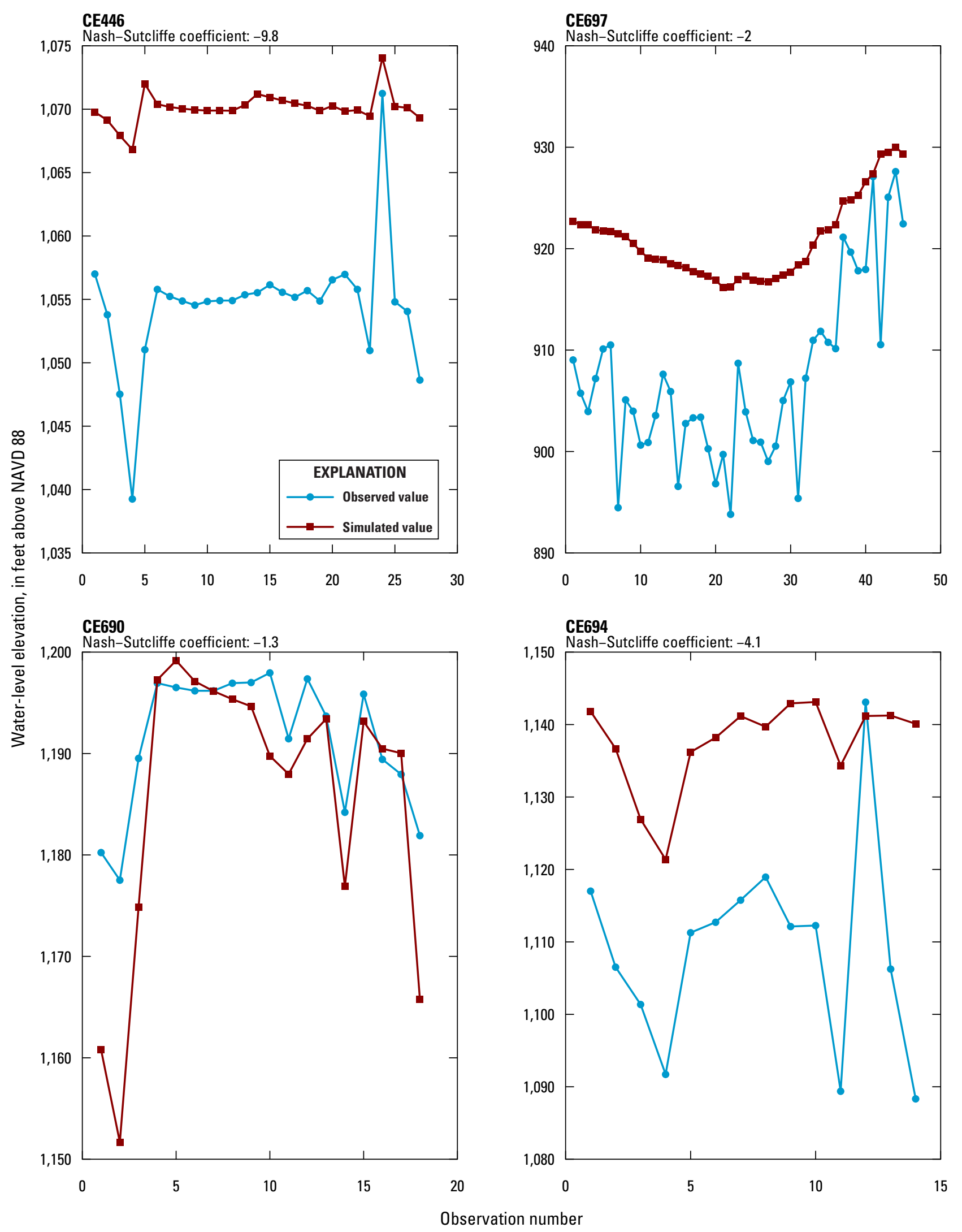

Figure A13. Observations and GSFLOW simulations of groundwater levels in selected wells in the Spring Creek and Nittany Creek Basins and parts of the Spruce Creek Basin, Centre and Huntingdon counties, Pennsylvania, water years $\approx 2000-06$. - Continued 
FILMORE 1

Nash-Sutcliffe coefficient: -28

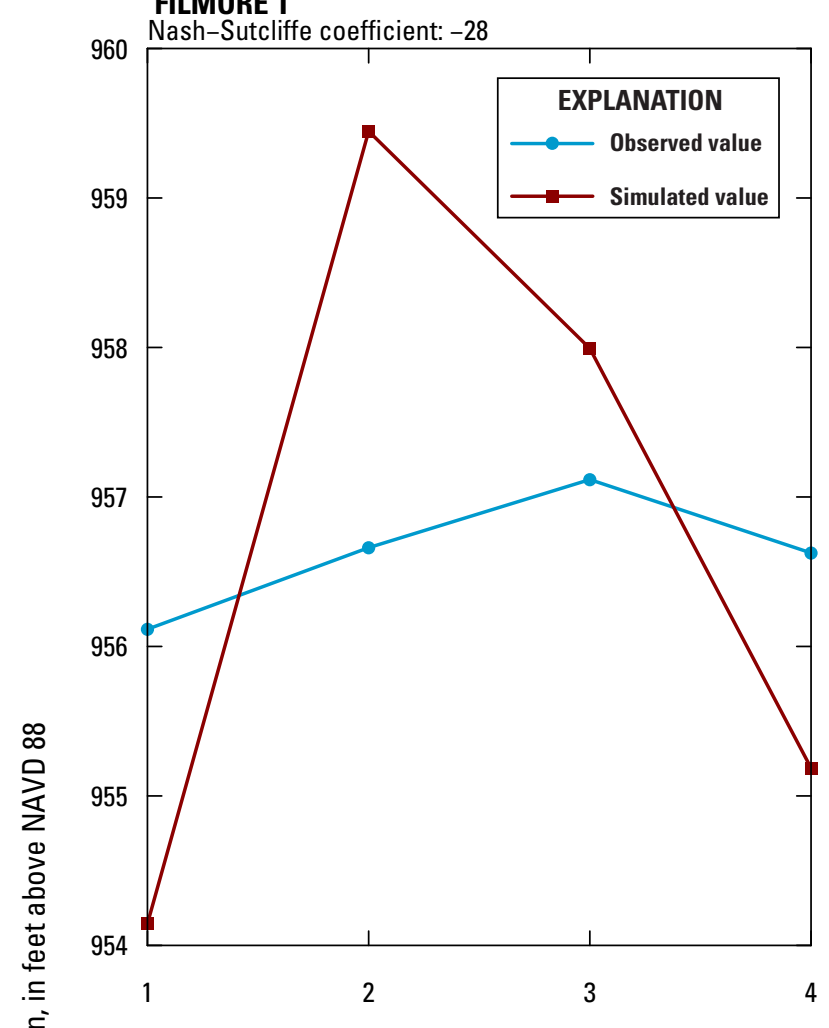

CE686

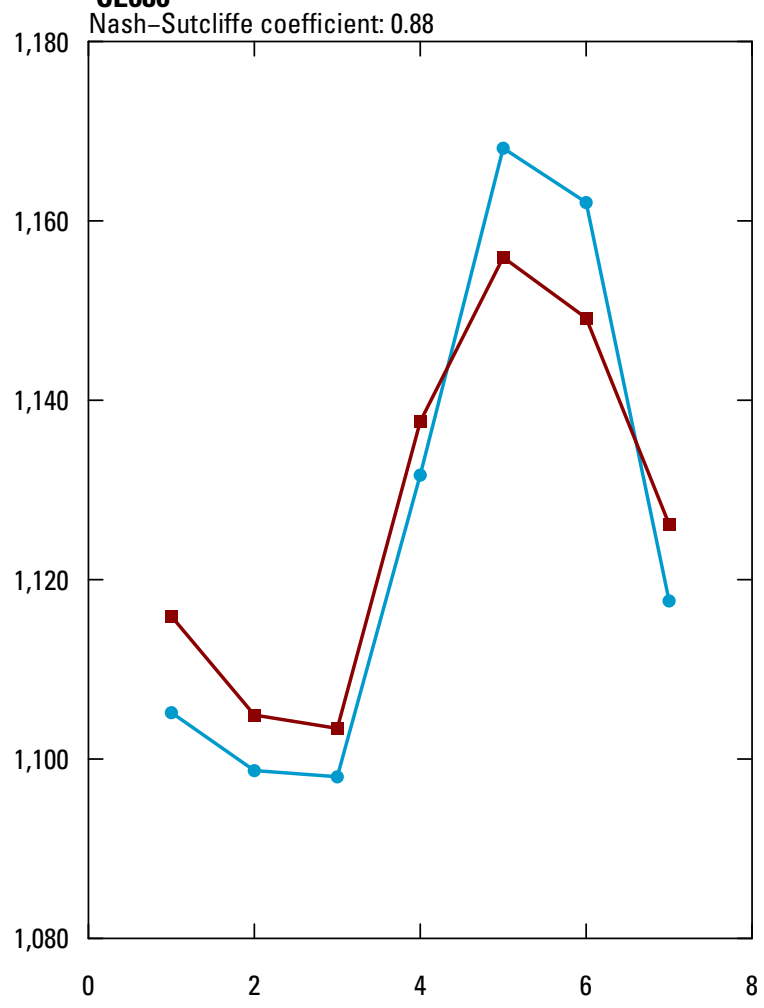

BIG HOLLOW

975 Nash-Sutcliffe coefficient: -2.7

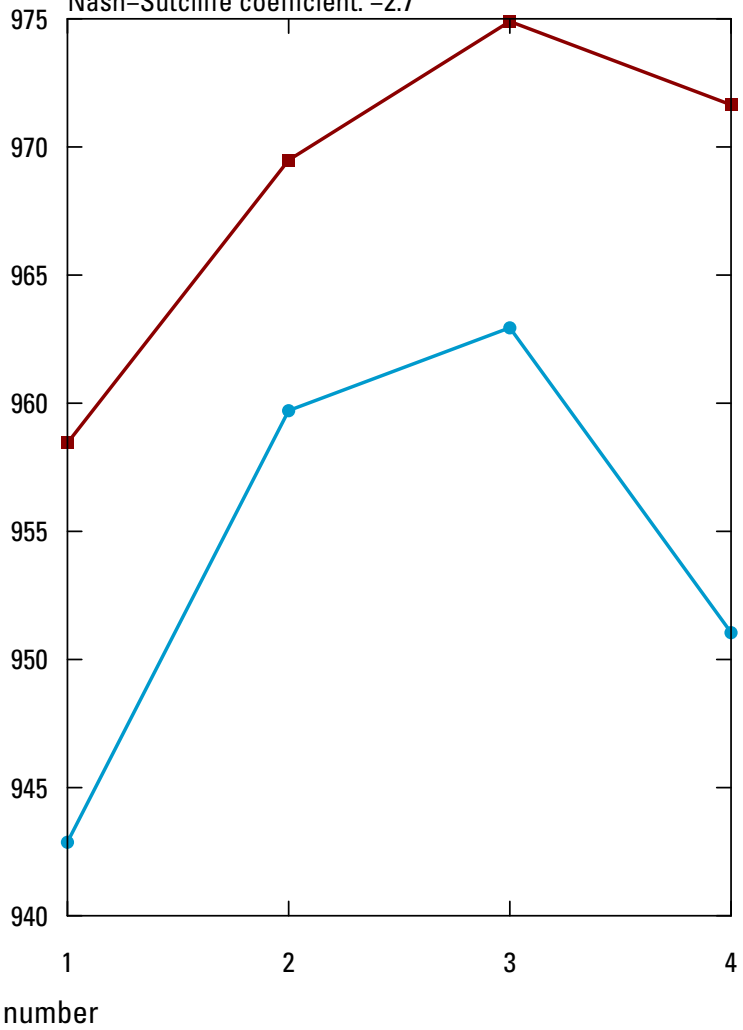

Figure A14. Observations and GSFLOW simulations of annual mean groundwater levels in selected wells in the Spring Creek and Nittany Creek Basins and parts of the Spruce Creek Basin, Centre and Huntingdon counties, Pennsylvania, water years $2000-06$. 


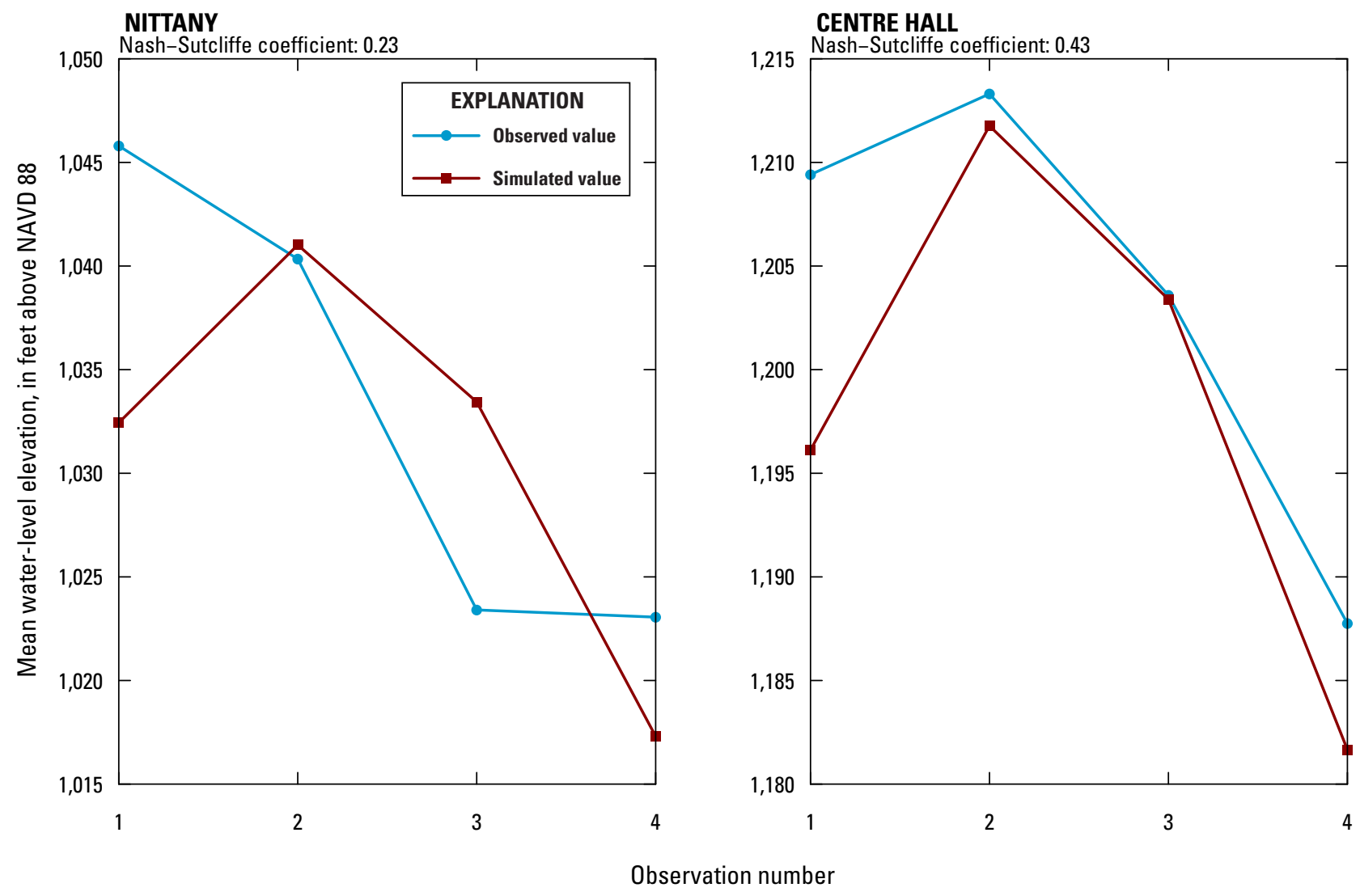

Figure A14. Observations and GSFLOW simulations of annual mean groundwater levels in selected wells in the Spring Creek and Nittany Creek Basins and parts of the Spruce Creek Basin, Centre and Huntingdon counties, Pennsylvania, water years 2000-06. - Continued 
For more information concerning this publication contact: Director, Pennsylvania Water Science Center U.S. Geological Survey

215 Limekiln Road

New Cumberland, PA 17070

Or visit:

http://pa.water.usgs.gov/

Document prepared by the West Trenton Publishing Service Center 
